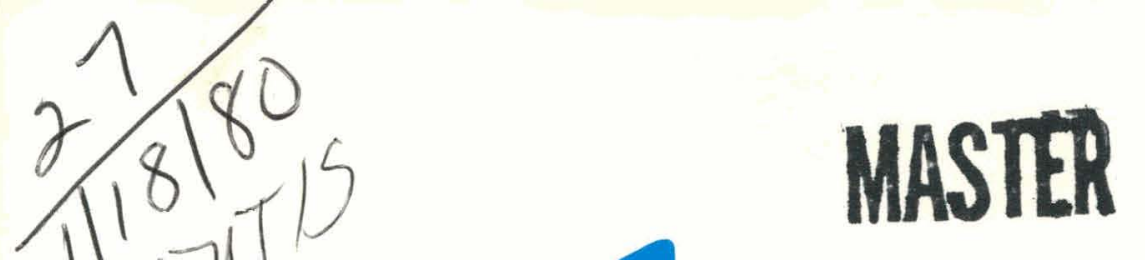

ORNL/TM-7059

\title{
Emergency Petroleum \\ Conservation: A Review \\ and Analysis of Selected Measures
}

UNION

CARBIDE

\author{
F. D. Boercker \\ M. Balasubramaniam \\ E. Hull \\ J. Savadelis \\ J. J. Valentini
}

OPERATED BY

UNION CARBIDE CORPORATION FOR THE UNITED STATES

DEPARTMENT OF ENERGY 


\section{DISCLAIMER}

This report was prepared as an account of work sponsored by an agency of the United States Government. Neither the United States Government nor any agency Thereof, nor any of their employees, makes any warranty, express or implied, or assumes any legal liability or responsibility for the accuracy, completeness, or usefulness of any information, apparatus, product, or process disclosed, or represents that its use would not infringe privately owned rights. Reference herein to any specific commercial product, process, or service by trade name, trademark, manufacturer, or otherwise does not necessarily constitute or imply its endorsement, recommendation, or favoring by the United States Government or any agency thereof. The views and opinions of authors expressed herein do not necessarily state or reflect those of the United States Government or any agency thereof. 


\section{DISCLAIMER}

Portions of this document may be illegible in electronic image products. Images are produced from the best available original document. 
Printed in the United States of America. Available from National Technical Information Service

U.S. Department of Commerce

5285 Port Royal Road, Springfield, Virginia 22161

NTIS price codes-Printed Copy: A08 Microfiche A01

This report was prepared as an account of work sponsored by an agency of the United States Government. Neither the United States nor any agency thereof, nor any of their employees, makes any warranty, expressed or implied, or assumes any legal liability or responsibility for any third party's use or the results of such use of any information, apparatus, product or process disclosed in this report, or represents that its use by such third party would not infringe privately owned rights. 
ORNL/TM-7059

Contract No. W-7405-eng-26

EMERGENCY PETROLEUM CONSERVATION:

A REVIEW AND ANALYSIS OF SELECTED MEASURES

F. D. Boercker

Energy Division/Oak Ridge National Laboratory

M. Balasubramaniam

E. Hull

J. Savadelis

J. J. Valentini

Energy Systems Group/TRW, Inc.

Prepared for
Office of Regulations and Emergency Planning
Economic Regulatory Administration

Date Published: January 1980

OAK RIDGE NATIONAL LABORATORY

Oak Ridge, Tennessee 37830

operated by

UNION CARBIDE CORPORATION

for the

DEPART'MENT' OF ENERGY

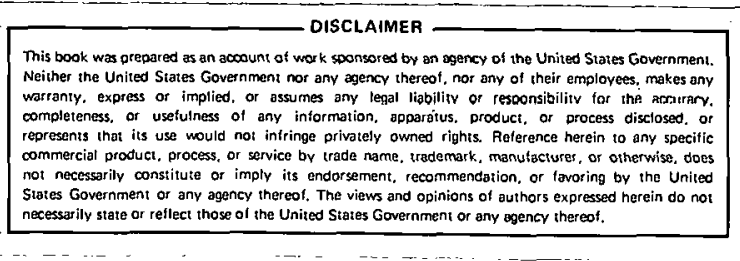


THIS PAGE

\section{WAS INTENTIONALLY LEFT BLANK}


CONTENTS

$\underline{\text { Page }}$

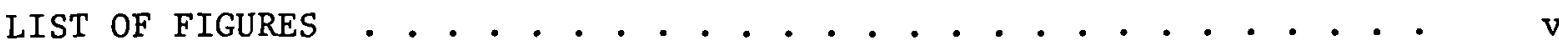

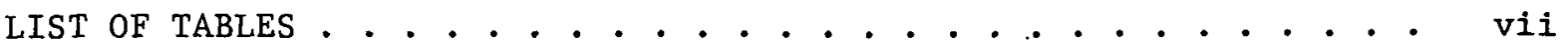

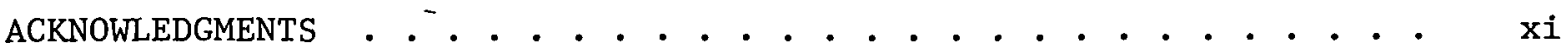

ABSTRACl . . . . . . . . . . . . . . . . . . . . . . . . . xiii

1. SUMMARY . . . . . . . . . . . . . . . . . . . . . . . . . . . . . . 1

1.1 List of Emergency Conservation Measures . . . . . . . . . 1

1.2 Restricted Hours of Operation for Commercial

Bulldings . . . . . . . . . . . . . . . . . . . . 2

1.3 Potential Energy Savings . . . . . . . . . . . . . . . 3

1.4 Economic Impacts . . . . . . . . . . . . . . . . . . . . 3

1.5 Environmental Impacts . . . . . . . . . . . . . . 6

1.6 Implementation Problems and Costs . . . . . . . . . . . . 7

2. INTRODUCTION . • . . . . . . . . . . . . . . . . . . . . . . . . 9

2.1 Background of the Study . . . . . . . . . . . . . . . . 9

2.1.1 EPCA guidelines . . . . . . . . . . . . . . . 10

2.1.2 ERA guidelines . . . . . . . . . . . . . . . 10

2.1.3 ORNL policy guidelines . . . . . . . . . . . . . 11

2.2 Work Plan for the Study . . . . . . . . . . . . . . . . . 11

2.2.1 Phase I: Review of possible measures . . . . . . . 11

2.2.2 Phase II: In-depth analysis of one measure . . . . 12

2.3 Caveats . . . . . . . . . . . . . . . . . 12

3. REVIEW OF EMERGENCY ENERGY CONSERVATION MEASURES

APPLICABLE TO RESIDENTIAL AND COMMERCIAL BUILDINGS AND

TO COMMERCIAL TRANSPORTATION . . . . . . . . . . . . . . . . . 14

3.1 Survey of Agencies . . . . . . . . . . . . . • . . . . . . 14

3.2 Literature Review . . . . . . . . . . . . . . . . . 15

3.3 Findings: Statistical Description of Energy Use, by

Sector, in the United States... . . . . . . . . . 16

3.4 Findings: A List of Potential Petroleum Conservation

Measures . . . . . . . . . . . . . . . . . . 22

3.4.1 Extended 1ist . . . . . . . . . . . . . . . . 22

3.4.2 First reduction of the 1ist . . . . . . . . . . 22

3.4 .3 Final list . . . . . . . . . . . . . . . . 23

4. IN-DEPTH ANALYSIS OF ONE MEASURE: RESTRICTED HOURS OF

OPERATION OF COMMERCIAL BUILDINGS . . . . . . . . . . . . . . . 29

4.1 Description of the Measure . . . . . . . . . . . . . . . . 29

4.2 Estimated Nationwide Energy Savings of the Measure . . . . 30

4.2.1 Estimated savings based on recent ASHRAE and

NPC studies . . . . . . . . . . . . . . . 31 
Page

4.2.2 Estimated energy savings based on application of ORNL data and models . . . . . . . . . . 33

4.2.2.1 Alternative methods of implementing the measure ....... . . . . . 37

4.2.2.2 Estimated energy savings for selected regions of the country........ 39

4.2.3 Summary ................. 43

4.3 Economic Impacts ...................... 45

4.3.1 Introduction and overview of results ........ 45

4.3.2 Factors influencing economy under regulation . . . 48

4.3.2.1 Commercial sector ........... 48

4.3.2.2 Income and employmenl effect. . . . . . 52

4.3.2.3 Sales effect............ . 55

4.3.2.4 Energy effect . . . . . . . . . . . 55

4.3.3 Detailed economic analysis of the regulation . . . 57

4.3.4 Regional economic impacts............ 60

4.4 Environmental Impacts ................. 67

4.4.1 Overview of results . . . . . . . . . . . 67

4.4.2 Energy impacts ................ 69

4.4.3 Air emission factors . . . . . . . . . . . . 70

4.4.4 Methodology to determine environmental

impacts . . . . . . . . . . . . . . . . . 71

4.4.5 Human factors aspect of regulation-induced

environmental impacts . . . . . . . . . . 72

4.5 Implementation.................. 73

4.5.1 Legal issues ................. 73

4.5.2 Other implementation problems.......... . 74

4.5.3 Implementation costs .......... 75

Appendix A. POSSIBLE EMERGENCY ENERGY (PETROLEUM) CONSERVATION

MEASURES: AN INITIAL LIST FOR SCREENING . . . . . . . A-1

Appendix B. REVIEW OF EMERGENCY CONSERVATION MEASURES . . . . . . . B-1

Appendix C. A REDUCED LIST OF PROPOSED MEASURES TO DECREASE

PETROLEUM CONSUMPTION . . . . . . . . . . . . C $\mathrm{C}-1$

Appendix D. SIMULATION OF ECONOMY IN THE ABSENCE OF

Appendix E. SIMULATION OF ECONOMY UNDER REGULATION.......$\quad$ E-1

Appendix F. DETERMINATION OF BASELINE CASE FOR ENVIRONMENTAL

Appendix G. LEGAL ISSUES ASSOCIATED WITH IMPLEMENTATION OF
THE EMERGENCY MEASURE . . . . . . . . . . . . . . G-1

Appendix H. AUTHORITIES, NEED, RATIONALE, OPERATION . . . . . . H-1 


\section{LIST OF FIGURES}

$\underline{\text { Figure }}$

1.1 The ten standard federal regions . . . . . . . . . . . 4

3.1 Imported share of U.S. 'domestic petroleum demand, $1970-77$. . . . . . . . . . . . . . . . . 16

3.2 U.S. crude oil imports by source region, 1976 . . . . . . 17

3.3 Proportion of total commercial sector energy supplied by petroleum by federal region, 1975 . . . . . . . . . . 21

4.1 Estimated annual energy use by restricted commercial sector, 1980 . . . . . . . . . . . . . . . . 30

4.2 Estimated annual fuel savings from $6 \%$ reduction in end-use energy by the restricted commercial sector, 1980

4.3 Impact of regulation on real GNP without commercial sector sales decline . . . . . . . . . . . . 58

4.4 Impact of regulation on real GNP with commercial sector sales decline . . . . . . . . . . . . 58

4.5 Impact of regulation on real gross private domestic fixed investment without commercial sector sales decline..................... . . 59

4.6 Impact of regulation on real gross private domestic fixed investment with commercial sector sales decline . . . 59

4.7 Impact of regulation on real personal disposable income wi thout commercial sector sales decline... . . . . . . 60

4.8 Impact of regulation on real personal disposable income with commercial sector sales decline . . . . . . . . . 60

4.9 Unemployment rate equivalent of income loss without commercial sector sales decline ............. 61

4.10 Unemployment rate equivalent of income loss with commercial sector sales decline . . . . . . . . . . . 61

4.11 Index of industrial production manufacturing in the baseline and regulated economies . . . . . . . . . . 61 
THIS PAGE

\section{WAS INTENTIONALLY LEFT BLANK}




\section{LIST OF TABLES}

$\underline{\text { Table }}$

3.1 U.S. energy consumption by fuel type, 1977 . . . . . . . . . 17

3.2 U.S. energy consumption by sector, by fuel type, 1975 . . . . 18

3.3 Distribution of energy use in transportation sector by mode of travel, 1977 . . . . . . . . . . . . . .

3.4 Regional patterns of petroleum consumption for residential, commercial, and transportation sectors, 1975

3.5 Emergency measures to reduce petroleum consumption in residential buildings . . . . . . . . . . . . . . 24

3.6 Emergency measures to reduce petroleum consumption in commercial buildings . . . . . . . . . . . . . . . .

3.7 Emergency measures to reduce petroleum consumption in commercial transportation . . . . . . . . . . . . 26

4.1 Energy savings through conservation (ASHRAE) . . . . . . . 32

4.2 Energy savings through conservation (National Petroleum Council) . . . . . . . . . . . . . . . . 32

4.3 Energy use in the commercial sector, by function, for four building operating conditions, 1980 projected

4.4 Aggregate economic impacts on selected variables rclative to baseline quarterly averages . . . . . . . . . 47

4.5 Regulation-induced losses in regional disposable income - 1980:4 through 1981:1

4.6 Regulation-induced increases in regional unemployment and resultant unemployment rates - 1980:4 through $1981: 3$

4.7 Commercial sector establishments affected by regulation limiting hours of nperation... . . . . . . . . . 51

4.8 National avcrage man-houre, wage rates, and employment in business establishments likely to be affected by regulation . . . . . . . . . . . . . . . 53

4.9 Regulation-induced income loss in the commercial sector. 
4.10 Regulation-induced reduction in commercial sector sales . . . 56

4.11 Energy effect of regulation . . . . . . . . . . . . 56

4.12 Key economic and demographic variables in 1980-81

relative to national (baseline case) . . . . . . . . . .

4.13 Regional shares of commercial sector activity in retail

trade and selected services relative to national

(baseline case 1980-81) . . . . . . . . . . . . . .

4.14 Regulation-induced reduction in wages and sales in the commercial sector 1980:4 through 1981:3 . . . . . . . . . 64

4.15 Regulation-induced losses in regional disposable income $-1980: 4$ through 1981:3 . . . . . . . . . . . .

4.16 Regulation-induced increases in regional unemployment and resultant unemployment rates - 1980:4 through 1981:3 . . . . . . . . . . . . ........

4.17 Emission changes at the national level from regulation restricting commercial sector operating hours . . . . . . . .

4.18 Emission changes at the regional level from regulation restricting commercial sector operating hours:

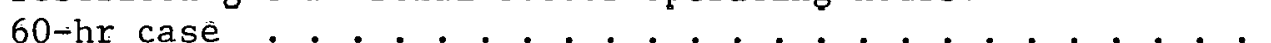

4.19 Regulation-induced shifts of petroleum fuels and natural gas at the national level from the commercial and utilitics sectors to the manufacturing scctor . . . . . . .

4.20 Regulation-induced shifts of petroleum and natural gas at the regional level from the commercial and utilities sectors to the manufacturing sector: 60-hr case . . . . . 70

4.21 Air emisssion factors derived from SEAS data base . . . . . 71

4.22 Estimates of implementation costs from related studies . . 76

D-1 Variableo influcncing baocline cconomy . . . . . . . . D-3

D-2 Selected measures of economic activity in baseline economy . . . . . . . . . . . . . . . . . D-4

E-1 Commercial sector establishments affected by rêgulation limiting hours of operation . . . . . . . . . . . E-2 
E-2 Annual sales and revenues in selected commercial establishments in the baseline economy . . . . . . . . . E-3

E-3 Lose in sales and revenues in selected commercial establishments from reduced operating hours . . . . . . . E-3

E-4 National average man-hours, wage rates, and employment in business establishments affected by regulation (data for baseline eronomy) . . . . . . . . . . E E-5

E-5 Regulation-induced income loss in the commercial sector . . E-6

E-6 Energy effect of regulation . . . . . . . . . . . . . E-8

E-7 Measures of economic activity under regulations . . . . . E-9

E-8 Measures of economic activity under regulations . . . . . . E-10

E-9 Measures of economic activity under regulations . . . . . . E-11

E-10 Measures of economic activity under regulations . . . . . . E-12

E-11 Unemployment equivalent of income loss at national level.................... . E-14

E-12 Unemployment rate equivalent of income loss at national level ................... E-14

E-13 DOE regions considered for analysis . . . . . . . . . E-15

E-14 Selected national and regional, economic and demographic variables . . . . . . . . . . . . . . . E-16

E-15 Selected regional economic and demographic variables relative to national . . . . . . . . . . . . . E-17

E-16 Regional shares of commercial sector activity in retail trade and selected services relative to national (1972) . . E-17

E-17 Regional shares of commercial sector activity in retail Lrale and selected services relative to national (baseline case 1980-81) . . . . . . . . . . . . E-18

F-1 Shifts in petroleum fuels and natural gas from the commercial and utilities sectors to the manufacturing sector under regulation restricting building temperatures 
F-2 Emission changes as a result of building temperature restriction . . . . . . . . . . . . . . . . . F-3

F-3 Emission data for the U.S. and selected regions . . . . . F-3

F-4 National and regional consumption of petroleum fuels in the manufacturing sector -1976 . . . . . . . . . . F-5 


\section{ACKNOWLEDGMENTS}

The authors wish to acknowledge support provided for this study by the Office of Regulations and Emergency Planning, Economic Regulatory Administration, DOE. The following staff of the Emergency Planning Division sponsored the work and provided programmatic guidance:

Denton Massell, Director, Emergency Planning Division

Walter Eckhardt

Andy Fang

Gregory Friedman

Sarah Kirchen

An overview committee was appointed at Oak Ridge National Laboratory to review progress and provide guidance to the study. The committee consisted of:

Ken R. Corum Garland Samuels

Other ORNL staff who made substantial contributions are:

Martha V. Adler

William S. Johnson (Consultant)

Roger Carlsmith

John B. Mills

Steve M. Cohn

Axe.1. R. Rose

David L. Greene

Carey S, Rosemarin

Eric A. Hirst

Robert T. McWhinney, Jr., of TRW made contributions to the economic and environmental analyses.

Cindy Eskridge typed the manuscript and coordinated reviews of the manuscript .

The contributions of each of the above are appreciated. 
THIS PAGE

\section{WAS INTENTIONALLY LEFT BLANK}


This is a report of work performed by Oak Ridge National Laboratory for the Economic Regulatory Administration. ORNL was asked to (1) collect, screen, and recommend a limited number of emergency measures that might conserve petroleum in residential and commercial buildings and in commercial transportation and (2) provide a detailed analysis of the energy savings and the economic and environmental impacts associated with restricting the hours of operation of commercial buildings. A total of 41 emergency measures were identified that might conserve petroleum, and these were reduced to a list of five that seemed most promising. Analysis of the measure to restrict hours of operation for commercial buildings shows that it might save 4 to $6 \%$ of annual commercial building energy use. The type of fuel conserved would vary widely from region to region, and appreciable negative economic impacts would result from implementing the measure. Results of the studies will be used by ERA in its efforts to devise petroleum conservation contingency plans as required by the Energy Policy and Contingency Act of 1975. 


\section{SUMMARY}

The Energy Policy and Contingency Act of 1975 required the president to submit petroleum conservation contingency plans to Congress for its approval. The Regulations and Emergency Planning Division of the Economic Regulatory Administration (ERA) was responsible for developing the plans, while Oak Ridge National Laboratory and others were asked to supply technical assistance in the formulation and evaluation of the plans. ORNL was responsible for two studies: (1) to collect, screen, and recommend a limited number of measures that might conserve petroleum in residential and commercial buildings and in commercial transportation and (2) to provide a detailed analysis of one of the recommended measures. This emergency measure would restrict hours of operation of commercial buildings to $60 \mathrm{hr} /$ week.

\subsection{List of Emergency Conservation Measures}

ORNL staff surveyed selected literature, contacted a number of public and private agencies, and assembled from these sources a list of 41 emergency conservation measures that might save appreciable amounts of energy, including petroleum. These 41 emergency measures were further screened down to five that seemed to bear the most promise:

1. Resldentlal building owners could reduce thermostat settings in winter and raise them in summer, use less hot water, reduce infiltration, and have furnace burners tuned. With reasonable compliance rates, such measures might save about 1 quad (or $400,000$ to $500,000 \mathrm{bbl} / \mathrm{day})$ of energy, including about $200,000 \mathrm{bb} 1 / \mathrm{day}$ of petroleum.*

\footnotetext{
${ }^{*}$ Note regarding units: ORNL policy is to use metric units, but the sponsoring agency for this study has requested that this report use conventional units. Conversion factors are:

1 British thermal unit $(B t u)=1055$ joules $(\mathrm{J})$

1 quadrillion $\mathrm{Btu}=1$ quad $=10^{15} \mathrm{Btu}=1.055 \times 10^{18} \mathrm{~J}=1.72 \times 10^{8} \mathrm{bb} 1$ of crude oil equivalent

1 barrel of crude oil equivalent energy $=5.8 \times 10^{6} \mathrm{Btu}=6.12 \times 10^{9} \mathrm{~J}$

$1 \mathrm{quad} /$ year $=472,000 \mathrm{bh} 1 / \mathrm{day}=1.055 \times 10^{18} \mathrm{~J} /$ year
} 
2. Building temperaturc restrictions could be mandated for commercial buildings. Depending on the severity of the restrictions and on the rigor of enforcement, savings might range from $2 / 3$ to almost 2 quads ( 300,000 to $1,000,000 \mathrm{bbl} / \mathrm{day}$ ) of energy, including about 100,000 to $300,000 \mathrm{bbl} /$ day of petroleum.

3. Commercial buildings could be restricted in their hours of operation. Depending again on the severity of the restriction, on whether additional temperature restrictions accompany the hours of curtailment, and on rigor of enforcement, savings might range from $1 / 3$ to $1 / 2$ quad ( 160,000 to $240,000 \mathrm{bbl} / \mathrm{day})$, including about $70,000 \mathrm{bb} 1 / \mathrm{day}$ of petroleum.

4. The 55-mph speed limit could be enforced on intercity trucking. Petroleum savings might amount to about $1 / 5$ quad ( $90,000 \mathrm{bbl} /$ day).

5. Reduced use of government trucks by 10 to $20 \%$ would result in a very small energy saving, but it would be useful as a symbolic measure.

At the time this study was being conducted, none of the above measures was in effect. However, recent federal actions have started implementatiun of the first two. The Residential Conservation Service (a part of the National Energy Act) is not an emergency measure, but its goal is to reduce residential energy consumption. The Emergency Bullding Temperature Restruction Plan (item 2 above) was put 1nto effect during the sumer of 1979. In addition, a number of federal agencies are reducing vehicle usage.

\subsection{Restricted Hours of Operation for Commercial Buildings}

After reviewing the list of possible emergency measures to reduce petroleum consumption, ERA asked ORNL staff to do an in-depth analysis of the measure to restrict hours of operation of commercial buildings. 'l'he measure, as defined, would limit hours of opening for commerclal buildings to $60 \mathrm{hr} /$ week, but it would provide some flexibility in choice of hours. It would also mandate temperature restrictions, beyond those specified in the Emergency Building Temperature Restriction Plan (EBTRP), to be in effect during hours of closure. The relationship between these two plans would be as follows: 
Winter

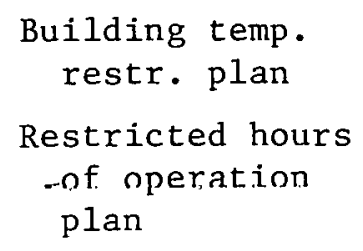

Summer

$$
80^{\circ} \mathrm{F} 24 \mathrm{hr} / \mathrm{day}
$$

$80^{\circ} \mathrm{F}$ when open $=60 \mathrm{hr} /$ week $55^{\circ} \mathrm{F}$ when closed $=108 \mathrm{hr} /$ week
No air conditioning when closed $=108 \mathrm{hr} /$ week

\subsection{Potential Energy Savings}

The Restricted Hours of Operation for Commercial Buildings Plan might save $1 / 3$ to $1 / 2$ quad of energy ( $(160,000$ to $240,000 \mathrm{bbl} /$ day) if it were rigorously enforced. These savings represent 4 to $6 \%$ of annual energy use by the commercial sector. Additional restrictions of commercial buildings to $40 \mathrm{hr} /$ week of operation would add little to the energy conserved.

Energy savings, by type of fuel saved, vary markedly from one region of the country to another. Detailed studies of federal regions. I, IV, and VI show that about $85 \%$ of the total energy saving in commercial buildings in region I would consist of petroleum; $87 \%$ of the savings in region VI would be natural gas; and the savings in region IV would be more evenly. divided among petrnleum, gas, and coal with the largest share to coal. Figure 1.1 identifies the federal regions.

\subsection{Economic Impacts}

- The 1mposition of regulation restricting hours of operation in the commercial sector can be expected to significantly affect several establishments in the retail trade and services divisions and to have a lesser or negligible effect on those in other divisions. Seven categories of business establishments were determined to be impacted under a $60-\mathrm{hr} /$ week restriction, with the number increasing to 12 under the more stringent $40-\mathrm{hr} /$ week restriction. If restricted to a $60-\mathrm{hr}$ week, the seven categories of commercial establishments would experience reductions in 


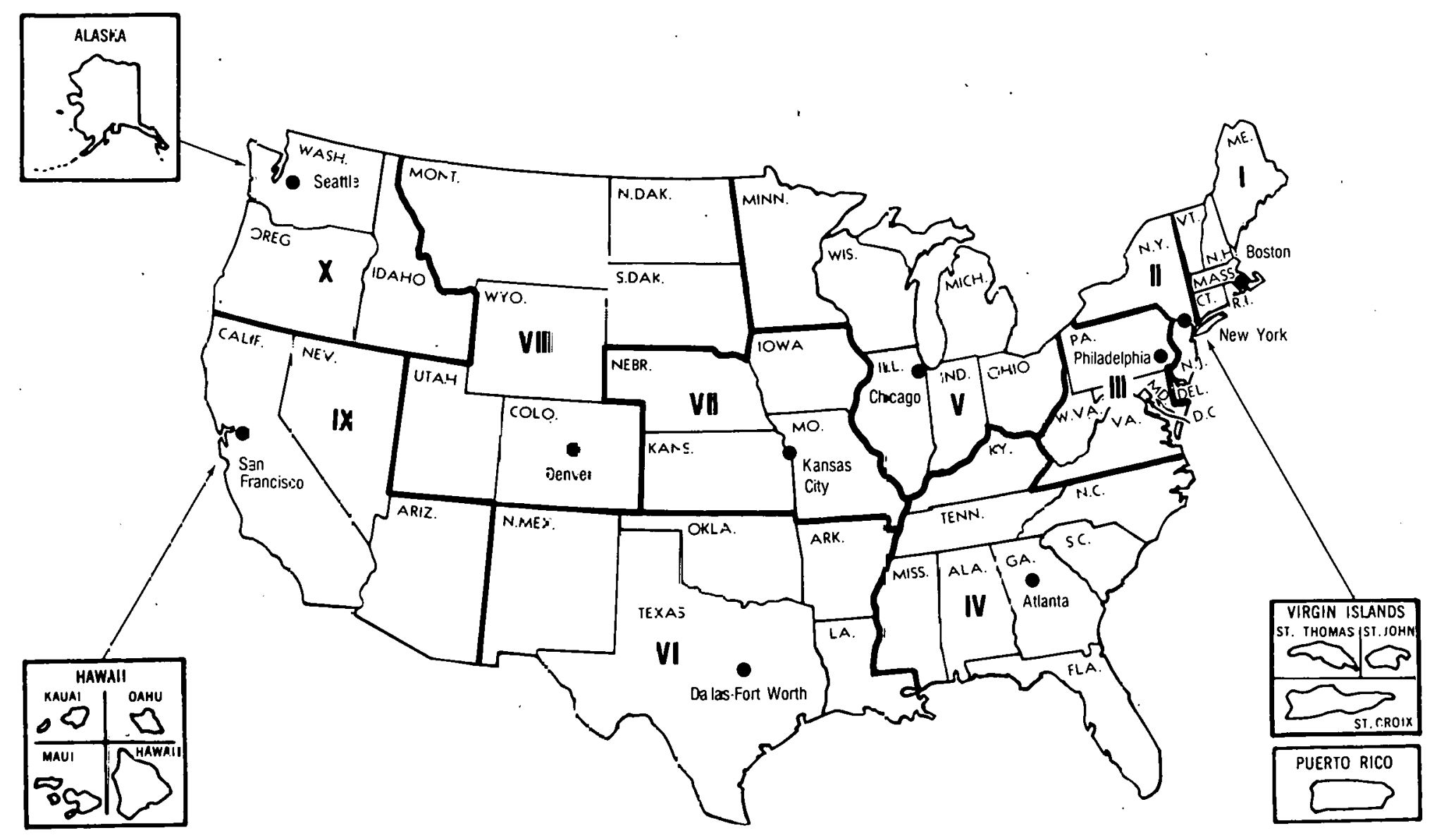

Fig. 1.1. The ten stardard federal regions. Source: United States Govermment Manual 1978/79, rev., Office of the Federal Register, National Archives and Records Serv., General Services Administration, Washington, D.C., 1978. 
operating hours ranging from 17 to 43\%; a 40-hr week would reduce operating hours of 12 categories of establishments from 17 to $62 \%$.

- The level of economic activity (measured over the 1980-81 baseline period) is adversely affected by the regulation even under conservative assumptions regarding effects of reduced operating hours on wages and sales in the commercial sector. The negative impacts worsen as the regulation becomes more restrictive.

- Direct wage loss in the commercial sector estimated in proportion to reduced operating hours of establishments was $\$ 4.5$ billion per year for a $60-\mathrm{hr}$ week and $\$ 13.0$ billion per year for a 40-hr week. In addition, there are secondary losses as lost purchasing power of displaced workers reduces effective demand throughout the economy.

- In addition to the loss in wages, loss in sales of commercial establishments may be a possible outcome of the regulation. Under conservative assumptions, the sales losses were estimated to range between $\$ 14$ billion per year with the 60-hr week and $\$ 41$ billion per year with the 40-hr week. The inclusion of these sales losses in the economic analyses results in negative impacts significantly in excess of those determined with wage losses alone.

- Direct employment effects of regulated hours are not easily determined because of uncertainties in the number of part-time and full-time employees that firms would choose to lay off as a result of regulation. However, an unemployment equivalent of the loss in income (direct and indirect) can be derived. Depending on whether sales are unaffected or affected by regulation, this unemployment equivalent at the national level ranges from 300,000 to 740,000 for a $60-\mathrm{hr}$ week and from 730,000 to $2,100,000$ for a 40 -hr week:

- The loss in personal income and the loss in sales (should that occur) will bulh result in reduced tax revenues to federal, state, and local governments. In addition to the decline in revenues, government transfer payments to the unemployed would increase. These effects, although not explicitly determined, are reflected in the overall response of the economy to the regulation. 
- Selected economic impacts were analyzed for DOE regions I, IV, and VI, considering regional employment, wages, and sales in commercial establishments. A11 three regions are adversely impacted by the regulation in proportion to the extent of their commercial sector activities relative to national levels.

- On an absolute basis, region IV would suffer the greatest loss in income and employment for all cases considered and region $I$ the least. On a relative basis (i.e., in relation to each region's baseline economic activity) the impacts on income and employment are similar to those determined nationally.

\subsection{Environmental Impacts}

- Regulation-induced impacts on the environment were determined on the assumption that direct and indirect savings in petroleum and natural gas resulting from restricted commercial sector operating hours would be used in the manufacturing sector. Savings in the utility use of coal were not assumed to be used elsewhere.

- Changes in emission levels (from a predetermined baseline) were estimated at the national and regional levels, considering only shifts in the patterns of use of petroleum and natural gas. These changes were found to be exceedingly small, probably well within the margins of error associated with data from the Strategic Environmental Assessment System model used in this study. Additionally, since savings in the use of coal by utilities were not assumed to be used elsewhere, it is reasonable to expect an overall reduction in emissions of all of the criteria pollutants considered (i.e., $\mathrm{NO}_{\mathrm{x}}$, $\mathrm{SO}_{\mathrm{x}}$, particulatco, $\mathrm{CO}$, and $\mathrm{HC}$ ).

- The human factors aspect addressing social implications of the regulation (such as economic equity, increased need for social services because of unemployment, etc.) are briefly described. While detailed analyses of these factors were outside the scope of this study, they are nevertheless identified because they are an important component of the regulatory decision-making process. 


\subsection{Implementation Problems and Costs}

Several kinds of problems might complicate implementation of the measure to restrict hours of operation of commercial buildings. None of these, however, would seem to provide insurmountable barriers.

Some of the problems are essentially legal in nature. For example, search warrants could be required for inspection of premises. Also, the equal protection right pursuant to the Fourteenth Amendment would require that any difference in treatment among parts of the commercial sector stand on a "rational basis" to survive constitutional challenge. Labor contracts vary in their manner of treating emergency closings, and layoff procedures should be investigated.

Enforcement of the measure would have to be carried out rigorously and impartially if energy savings are to be realized. This enforcement would require improved federal-state-private-sector communication, training sessions for enforcement officers, institution of an appeal procedure, and clear definition of a "trigger point" for implementation of the measure.

Logistic problems include the preparation, printing, and distribution of large numbers of materials describing the regulation.

Implementation costs to federal and state governments are difficult to anticipate. The measure could be enforced with any degree of vigor with corresponding variations in energy savings. Reasonably rigorous enforcement costs might fall in the range $\$ 35$ million to $\$ 50$ million per year. If the measure were implemented in conjunction with the EBTRP, the implementation costs could be shared between the two plans.

Overall, the probable negative economic impacts associated with the measure seem to outweigh the positive values of energy savings. The ORNL study staff suggest that if, or when, the country is faced with a severe. petroleum shortage requiring marked reduction in consumption, the government might mandate a "percenlage reduction contingency plan." Each geographic sector would be allocated a percentage amount of petroleum calculated on an arbitrary base period and would cope with this reduction, using any and all measures that seem appropriate to the particular area. 
Most state energy office staff who were contacted by ORNL agreed that such an approach was more effective and caused less unfavorable public reaction than uniformly mandated measures. It would appear that a detailed analysis of a percentage allocation approach, similar to this analysis, would be desirable. 


\section{INTRODUCTION}

\subsection{Background of the Study}

During the past six years, beginning with the OPEC oil embargo of 1973-74 and extending through the gasoline shortages of 1979, the federal government has become increasingly concerned about measures to deal with petroleum shortages. This concern resulted in passage of the Energy Policy and Conservation Act of 1975, requiring the president to submit contingency plans to Congress for its approval. The Regulations and Emergency Planning Division of the Economic Regulatory Administration (ERA) was responsible for developing these emergency contingency plans.

In September 1978, staff from the Energy Division of Oak Ridge National Laboratory met with ERA staff to identify areas in which ORNL could supply technical support in developing the contingency plans. The support project would be a continuation. of work by ORNL on problems associated with periodic shortfalls of natural gas. It was decided that ORNL staff should shift their attention to emergency measures that could conserve petroleum in the event of a severe interruption of foreign oil supply. Specifically, ORNL was asked to undertake two studies:

- Collect, screen, and recommend a very limited number of measures that could conserve oil in residential and commercial buildings and in commercial transportation. These measures were to conform to Energy Policy and Contingency Act (EPCA) guidelines.

- Provide a detailed analysis of potential energy savings and probable economic and environmental impacts of one of the measures. The measure to be analyzed was to be selected by ERA staff.

Other agencies, working with ERA, were to screen and analyze measures in other sectors, such as industrial energy use and private automobile energy use.

This report summarizes findings of the two studies undertaken by ORNL. Certain portions of the studies were subcontracted to the Energy Systems Group of TRW, and their staff conducted investigations on economic and environmental impacts of the measure selected by ERA for in-depth analysis. 
Because the project was to supply suggestions for, and analyze impacts of, standby emergency regulations as called for in EPCA and developed by ERA, it was necessary to consider the basic guidelines for such measures as put forth by EPCA and ERA. ORNL also has guidelines relevant to the project.

\subsubsection{EPCA guidelines}

EPCA defines "emergency measures" as actions that

- decrease demand and do not increase supply;

- remain in effect initially for no more than nine months;

- may not impose a tax or user fee, may not price petroleum, and may not provide tax rebates;

- apply to all states;

- deal only with one logically consistent subject matter. Because these emergency measures are designed to remain in effect for less than a year, they must be amenable to implementation within a few weeks.

Such emergency measures may be put Into effect to counteract emergency petroleum shortages brought on by an embargo, sabotage to an oil supply, or "act of God." It is assumed that an embargo is the most likely of these emergencies.

\subsubsection{ERA guidelines}

The Regulations and Emergency Planning Division of ERA felt that the project should be approached in two steps:

- Phase I should provide a well-screened 1ist of emergency measures for residential and commercial buildings and for commercial transportation. The results should include first-order estimates of petroleum-energy savings for each measure.

- Phase II should provide a detailed analysis of petroleum-energy savings and detailed information on likely economic and environmental impacts for a specific measure selected by ERA. National average results should be supplemented with selected regional detail. 


\subsubsection{ORNL policy guidelines}

ORNL policy does not allow staff to write regulations. Therefore, ORNL participation in phase I of the project was understood to be limited to collecting a list of possible emergency measures, screening the measures by use of EPCA and ERA guidelines, and presenting a small list of we11screened measures to ERA accompanied by estimates of petroleum savings for each measure. Likewise, the detailed analysis in phase II was understood to include only a technical analysis from which ERA staff could juage the suitability of the selected measure for consideration as a proposed regulation.

\subsection{Work Plan for the Study}

\subsubsection{Phase I: Review of possible measures}

The work plan called for ORNL to undertake the following tasks over a period of about two months:

- Collect suggestions for possible emergency conservation measures by visiting a large number of agencies, public and private, that were working professionally in conservation and/or studying petroleum utilization.

- Collect conservation suggestions through a literature search on responses to the 1973-74 embargo.

- Collect conservation suggestions by calling energy offices in states that had been heavily impacted by the 1973-74 embargn.

- Collect suggestions from ORNL staff and Brookhaven National Laboratory staff.

- Collect information from federal agencies and from the American Petroleum Institute regarding petroleum use by sector, by U.S. census region.

- Compile the suggested emergency energy (petroleum) conservation measurcs into a single list. 
- Reduce the long list, using the experience of .ORNL conservation specialists, to a short, well-screened list.

- Provide first-order estimates of petroleum savings for each of the final mcasures.

- Report the results to ERA.

\subsubsection{Phase II: In-depth analysis of one measure}

The following phase II projects were scheduled for completion within seven months:

- With building energy use models and energy data series avallable within the Energy Division, the ORNL staff would estlmate potential energy-petroleum savings resulting from the selected conservation measure.

- ORNL staff would estimate costs of implementing the measure and identify any legal constraints to implementation.

- Probable economic and environmental impacts associated with the selected conservation measure would be analyzed by an outside agency through subcontract.

\subsection{Caveats}

Analysis of the impacts of various conservation measures will not yield precise results, given the present level of data availability and the state of the art in analyzing complex technical-social phenomena. Data describing energy consumption, by sector, by fuel type, and by geographic region, generally become available only after 4 to 5 years. Different data sources use different definitions and supply different totals. Heat transfer characteristics of various building stocks in different climates are not well documented. Tendencies of the public to comply with, or resist, specific types of regulations are unknown. Few empirical data exist regarding the complex soctal and economic events that would be triggered by the conservation measures considered in this study. Therefore, while the authors have presented as much quantitative 
analysis as time and data availability allow, they have supplemented this with qualitative discussions to fill in the inevitable gaps. Most results are presented as ranges of values. The report should supply ERA staff with a useful analysis, but the results should be interpreted with care and sectional caveats observed. 
3. REVIEW OF EMERGENCY ENERGY CONSERVATION MEASURES APPLICABLE TO RESIDENTIAL AND COMMERCIAL BUILDINGS AND TO

COMMERCIAL TRANSPORTATION

\subsection{Survey of Agencies}

As a first step in collecting suggestions for emergency petroleum conservation measures, ORNL staff visited with, or made telephone calls to, a number of agencies that were knowledgeable about conservation and/or the petroleum industry. The interviews were designed to find out (1) whether the agency was already engaged in a study that overlapped the objectives of this project, (2) whether the agency representatives had suggestions for measures that they felt should be considered for inclusion in the ORNL list, and (3) whether the agency had recent statistics on petroleum consumption and on possible petroleum savings related to specific conservation measures.

The following agencies were contacted:

Federal and "quasi-federal agencies"

- Conservation and Solar Applications/DOE.

- Department of Transportation.

- Interstate Commerce Commission.

- National Academy of Sciences, Building Kesearch Advisory Council.

- National Petroleum Council.

- Regulation and Emergency Planning/ERA/DOE.

- Strategic and Contingency Planning, Policy, and Evaluation/DOE.

State agencies

- State energy offices in ten states that were heavily dependent upon petroleum and had been severely impacted by the 1973-74 embargo. The states were: California, Connecticut, Florida, Maine, Massachusetts, New Jersey, North Carolina, North Dakota, Oregon, and Wisconsin. 


\section{Private sector}

- American Petroleum Institute, Washington, D.C.

- National Association of Home Builders Research Foundation, Washington, D.C.

- Syska \& Hennessy, New York, New York.

- Tishman Research Corporation, New York, New York.

In addition to surveying the above-mentioned outside agencies, interviews were held with ORNL professional staff who were engaged in conservation studies related to residential and commercial buildings and transportation. David Pilati of Brookhaven National Laboratory also provided reprints of studies he had conducted that were relevant to the ORNL interests.

Specific findings are provided in the following section, but in general the federal agencies, with the exception of the Economic Regulatory Administration (ERA), were not working with emergency conservation measures. Several were concerned with long-term conservation measures. The state energy offices have been working out emergency plans for coping with various kinds of energy shortfalls. They represent a reservoir of experience that should be tapped more deeply and Eyetcmatically if federal eñergency plans and state plans are to reinforce each other. The private-sector agencies and the National Petroleum Council were a good source of relevant statistics.

\subsection{Literature Review}

Using the New York Times Index and the Reader's Guide to Periodical Literature, a survey was conducted of news articles and of articles in popular journals during the 1973-74 embargo. The survey was concerned with reported methods of coping with petroleum shortfalls both in the United States and abroad. This activity was not very productive because most of the popular reports focused on the impacts on private automobile transportation, which was not an area of ORNL responsibility. 
3.3 Findings: Statistical Description of Energy Use, by Sector, in the United States

Because this study is designed to identify emergency petroleum conservation measures that could be placed in operation in the event of an oil embargo, it is necessary to have some general picture of the sources of petroleum and the use, by sector, of that petroleum.

Figure 3.1 illustrates the current "American Tradegy" - the steady increase in demand for petroleum coupled with a rapid increase in the percentage of imported petroleum. The 1973-74 embargo caused a perturbation in the general growth trend, but the increases seemingly have resumed. The 1979 gasoline shortage may cause another fluctuation. Figure 3.2 shows a breakout of the regional sources of imported petroleum. Almost two-thirds of imported petroleum comes from OPEC nations, and about half of OPEC petroleum comes from Arab OPEC nations.

Petroleum now accounts for almost half of the entire U.S. energy consumption (see Table 3.1).

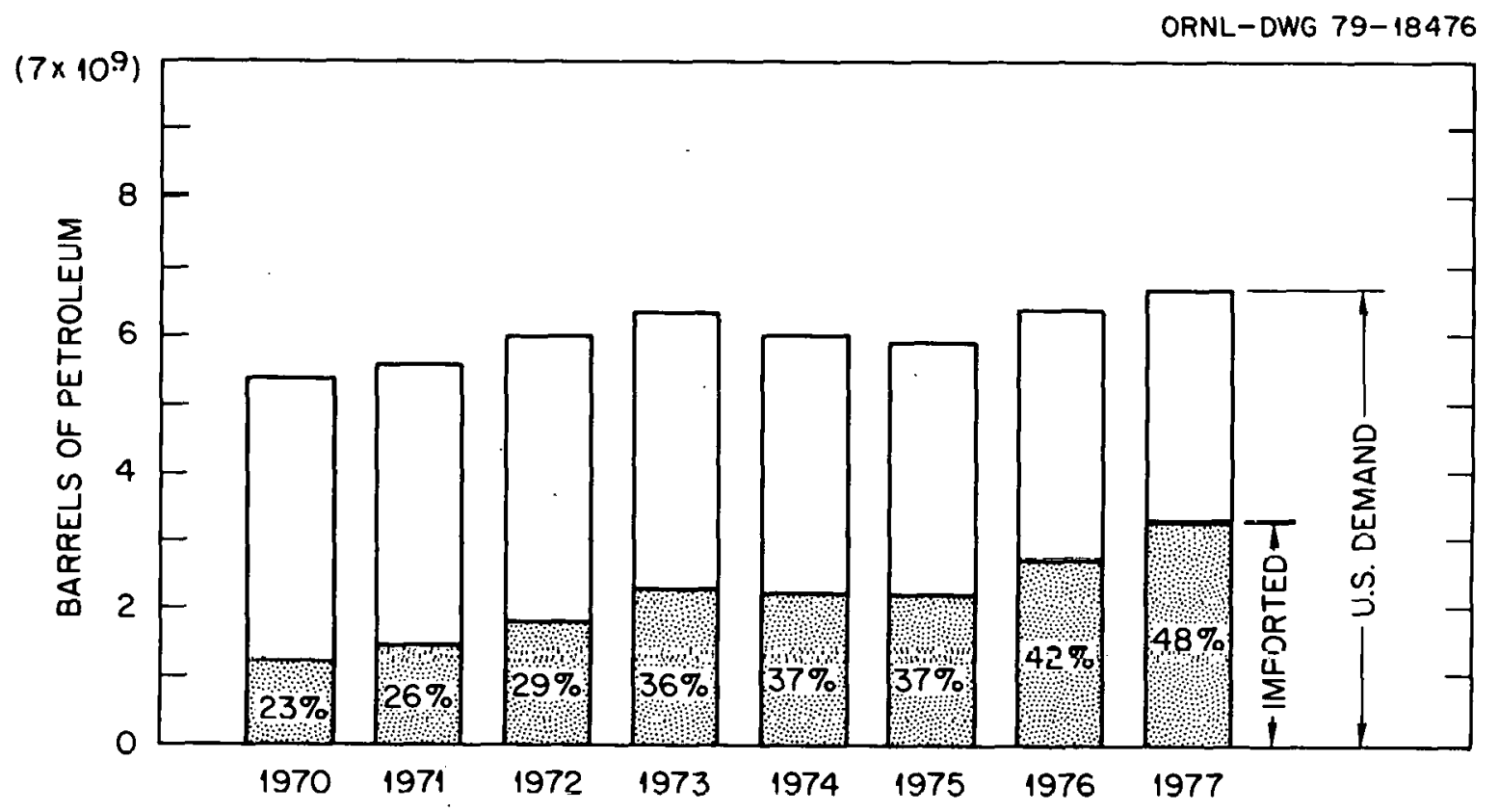

F1y. 3.1. Imported share of U.S. domest1c petroleum demand, 1970-77. Source: Annual Report to Congress, Volume III, 1977, Statistics and Trends of Energy Supply, Demand, and Prices, p. 23, Energy Information Administration, Washington, D.C., 1978. 
Table 3.2 shows the pattern for energy use in the United States during 1975. Although energy use has increased since 1975, the basic

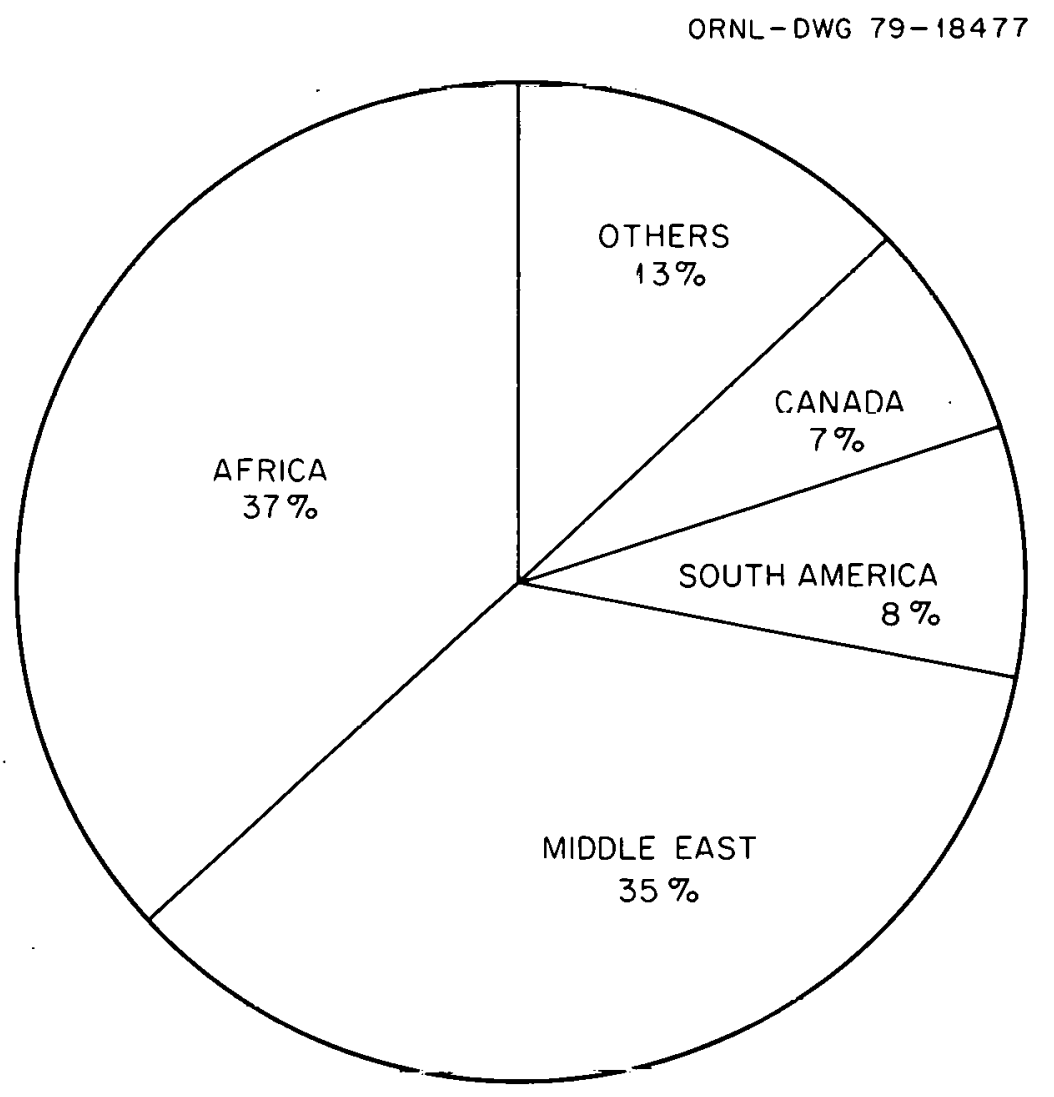

Fig. 3.2. U.S. crude oil imports by source region, 1976 . Source: Basic Petroleum Data Book, p. 76, American Petroleum Institute, Washingt on, D.C.

Table 3.1. U.S. energy consumption by fuel type, 1977

\begin{tabular}{lcc}
\hline Petroleum & 37.0 quads $^{a}$ & $49 \%$ \\
Natural gas & 19.6 & 26 \\
Coal & 14.1 & 19 \\
Nuclear & 2.7 & 3 \\
Hydro $\quad \underline{2.4}$ & -3 \\
\hline \multicolumn{1}{c}{ Total } & 78.8 quads & $100 \%$ \\
\hline
\end{tabular}

$a_{1}$ quadrillion Btu $=10^{15}$ Btu. Source: Annual Report to Congress, Volume III, 1977, Statistics and Trends of Energy Supply, Demand, and Prices, p. 5, Energy Tnformation Administration, Washington, D.C., 1978. 
Table 3.2. U.S. energy consumption by sector, by fuel type, 1975

\begin{tabular}{lrrrrrrrr}
\hline \multirow{2}{*}{$\begin{array}{l}\text { Sector of } \\
\text { economy }\end{array}$} & \multicolumn{6}{c}{ Energy use by $^{\alpha}$ fuel type (trillions of Btu) } & \multirow{2}{*}{ Total } \\
\cline { 2 - 6 } & Petrol. & Nat. gas & Coal & Nuc1. & Hydro & Other & \\
\hline Commercial & 2,715 & 3,297 & 1,575 & 409 & 542 & 4 & 8,542 \\
Residential & 5,263 & 6,416 & 2,698 & 612 & 922 & 4 & 15,915 \\
Indus. + agri. & 8,832 & 8,253 & 6,783 & 560 & 1,095 & 4 & 25,527 \\
Transportation $b$ & 17,177 & 764 & 101 & 27 & 36 & 18,105 \\
Military & 278 & 80 & 36 & 13 & 19 & 426 \\
$\quad$ Total & 34,265 & 18,810 & 11,193 & 1,621 & 2,614 & 12 & $68,515^{c}$ \\
\hline
\end{tabular}

$u_{\text {Electricity end }}$ use has been converted $c 0$ primlly fuel ised in gencration and distribution. The conversions were computed by applying the fuel consumption Alstrluuliun in the utility eactor as provided in the Regional Energy Balance Statement Tables. See: Energy Availability for state urul Local Development: 1975 Data Volume, J. B. Mills, P. L. Rice, D. P. Vogt, ORNL/TM-6951 (forthcoming).

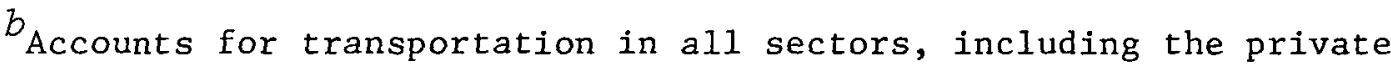
automobile.

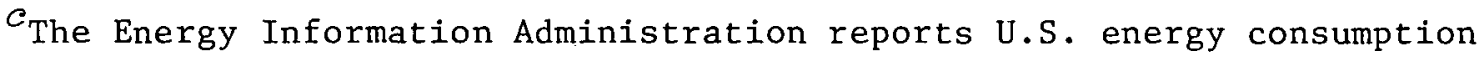
for 1975 to be 70,598 trillion Btu or $3 \%$ higher than this total. The difference is primarily in accounting for the energy used to generate electricity and to process oil and gas.

Source: Regional Economics Group, ORNL, 1979, Regional Energy Balance Statement, 1975.

pattern has not changed appreciably. The largest use for petroleum is in transportation, followed by industry and agriculture. Resdential and commercial uses, excluding transporation, account for about 8 quads of petroleum ( 3.8 million bbl/day) or about one-fourth of U.S, petroleum consumption. Petroleum accounts for one-third of the nontransportation energy use of the commercial, resident1al, and industrial sectors.

Table 3.3 shows how the energy (virtually all petroleum) used in transportation is distributed among various modes of travel. Passenger automobiles account for about half of transportation energy use, and commercial transportation accounts for the rerlainder (8.7 quads or 4.1 million bbl/day). The sectors of concern in this study use almost half of all U.S. petroleum (residential, 15\%; commercial, $8 \%$; and commercial transportation, $25 \%$ ). 
Table 3.3. Distribution of energy use in the transportation sector by mode of travel, 1977

\begin{tabular}{lcc}
\hline Travel mode & Transportation energy use (\%) \\
\hline Highway & & 78.6 \\
Passenger car and motorcycle & 52.3 & \\
Bus & 0.7 & \\
Truck & 25.6 & \\
Nonhighway & & \\
Rail & 3.1 & \\
Air & 8.4 & \\
Marine & 5.7 & \\
Pipeline & 2.9 \\
Other & 1.3 & $\overline{100.0}$ \\
\end{tabular}

Source: Shonka, D. B. (Ed.), Transportation Energy Conservation Data Book: Edition 3, ORNL-5493 (February 1979), p. xxvii.

Since the purpose of this study is to identify potential conservation measures that would save petroleum in residential and commercial buildings and in commercial transportation, it is important to understand something about the dependence of each of the sectors on petroleum and how this dependence varies regiunally. lihese data are displayed in Table 3.4; the federal. regions referred to in the table are 1dentified in Fig. 3.3.

Federal regions I and II use large absolute amounts of petroleum, which comprises very large percentages of total energy use in residential and commercial buildings. Regions TV and V also use large amounts of petroleum in these sectors, but the percentage dependence is lower. Regions VI to $X$, the western half of the country, use much smaller amounts of petroleum, and it accounts for one-fourth or less of total residential and commercial building energy use. The largest absolute consumption of petroleum for transportation, including private autos and commercial and industrial vehicles, occurs ini reglons $\mathrm{IV}, \mathrm{V}, \mathrm{VI}$, and IX.

In summary, this brief analysis of data Indicates:

- The United States is heavily dependent upon petroleum, using it to supply almost half of all energy ronsumed in the country. 
Table 3.4. Regional patterns of petroleum consumption for residential, comnercial, and transportation sectors, -975

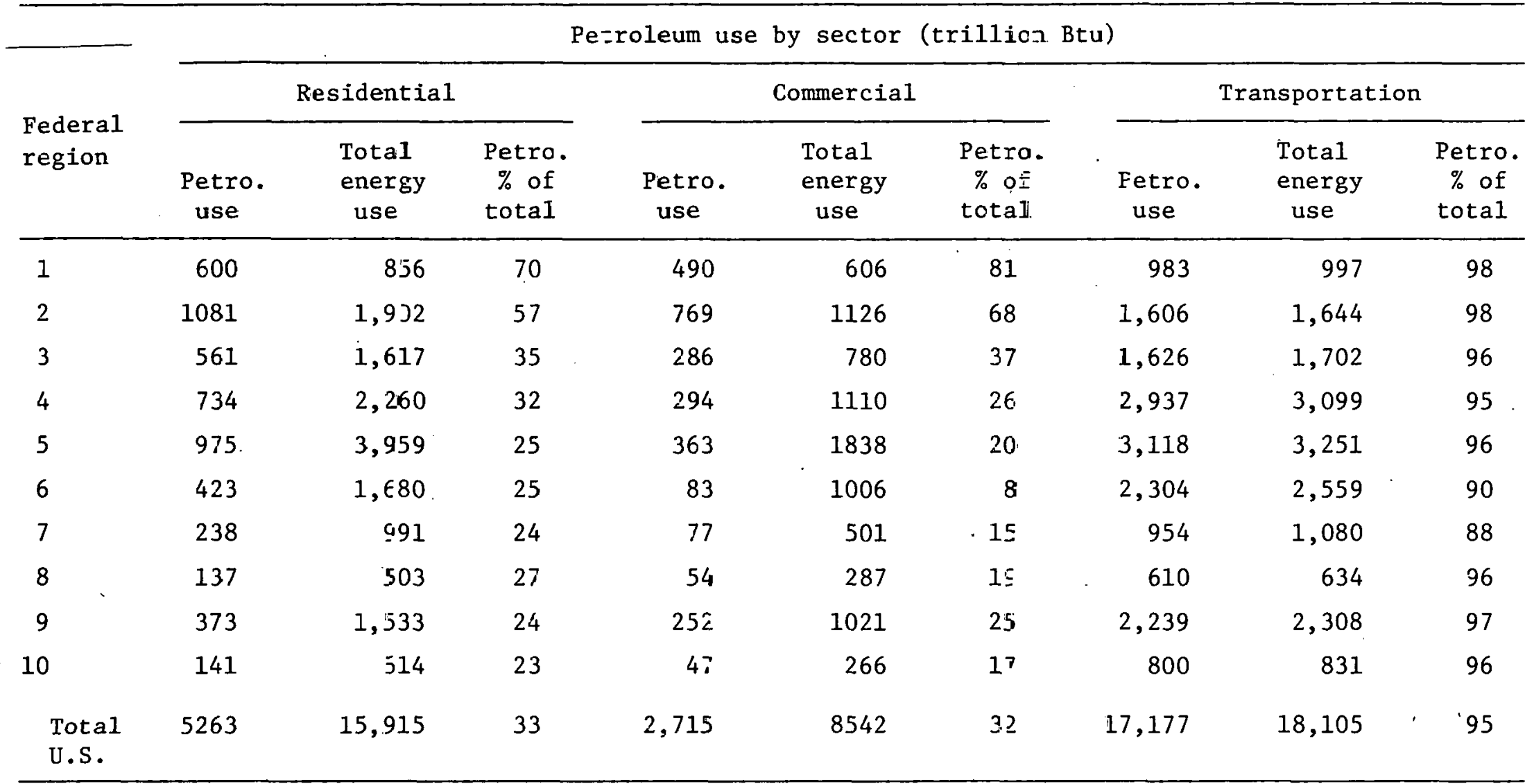

Source: Regional Economics Group., DRNL, 1э79, Regional Energy Ealance Statement, 1975, special tabulation. 


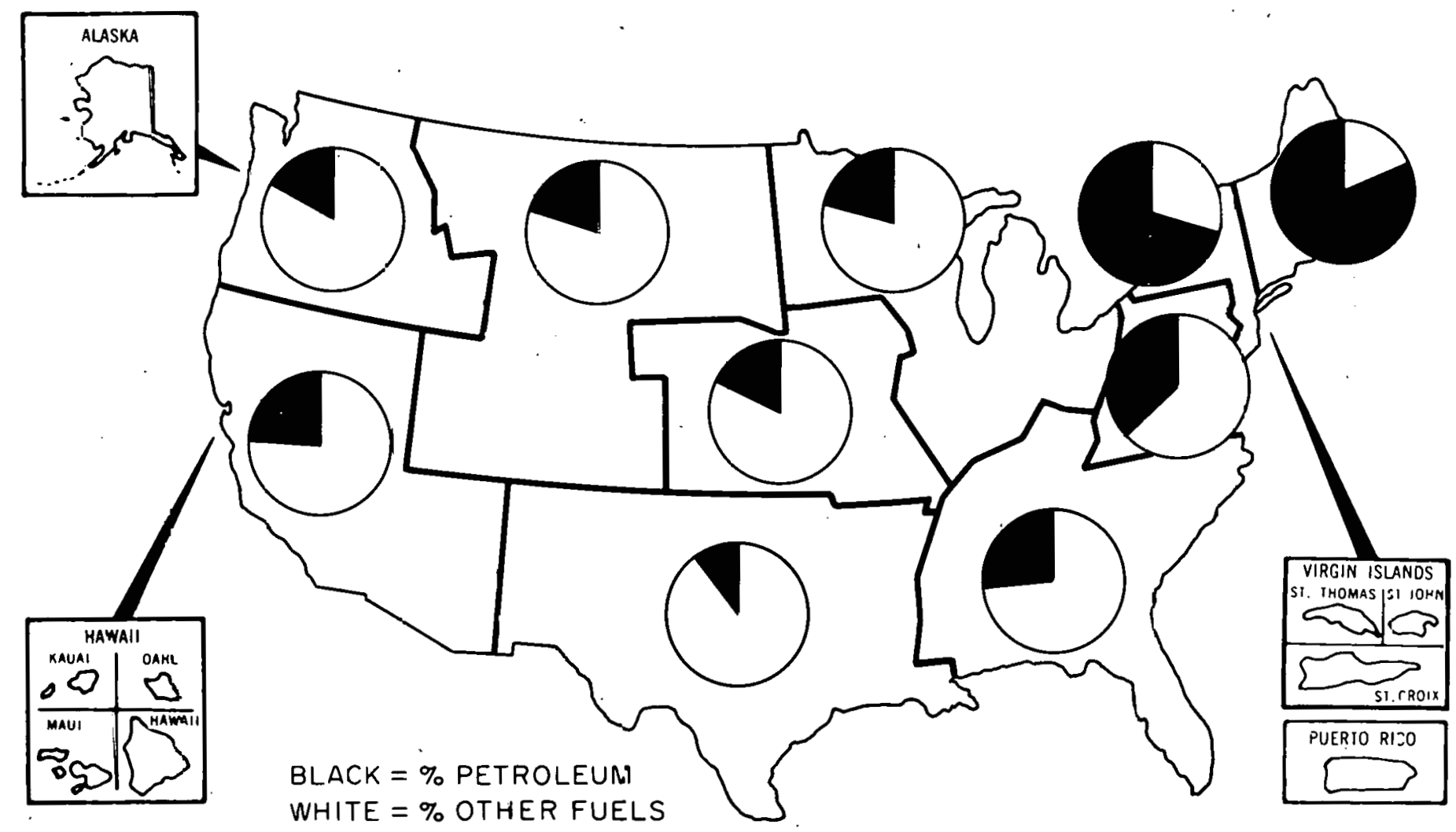

Fig. 3.3. Proportion of total commercial sector energy supplied by petroleum by fecieral region, 1975. Source: Regional Economics Group, ORNL, 1979, Regional Energy Balance Statement, 1975, special tabulation. 
- Petroleum consumption is increasing each year, and imported petroleum makes up a rapidly increasing proportion of petroleum use.

- Almost two-thirds of imported petroleum comes from OPEC. The United States has become ever more vulnerable to actions that restrict petroleum imports.

- Residential and commercial sectors plus commercial transportation account for about half the total energy use in the country.

- Different regions of the country display very different degrees of reliance on petroleum to supply residential and commercial energy. The New England and the mid-Atlantic reginns arc especially dependent on petroleum.

\subsection{Findings: A List of Potential Petroleum Conservation Measures}

\subsubsection{Extended 1ist}

As $a$ result of visits with staff in the various federal, state, and private sector agencies, conferences with in-house staff, and the literature review, a large number of possible emergency measures were assembled. These ranged from the serinus (reduce thermostat settings) to the not so serious (ban miniskirts). In all, 41 potentially useful measures were assembled (see Appendix A). This list was sent to a selected group of ORNL staff with the request that they review it and then meet to help reduce the list.

\subsubsection{First reduction of the list}

Each of the three sections of the list of measures (residential, commercial, and commercial transportation) was reviewed by a separatc group of ORNL staff with expertise in the area. The major criteria for the first reduction were: (1) possibility of petroleum saving and (2) minimum economic impact. As a result of thie review, the list was reduced to 16 measures. Appendix $B$ indicates, for each of the original 41 measures, the reviewers' recommendations and the reasons for the recommendations. 
For each of the remaining 16 measures, preliminary estimates of possible petroleum savings were obtained from the ORNL staff. This reduced list of 16 measures (see Appendix $C$ ) was sent again to the selected ORNL staff members for review, and a second set of group meetings further reduced the list to a final set of measures that would be proposed to ERA.

\subsubsection{Final 1ist}

Tables $3.5,3.6$, and 3.7 list the measures that ORNL staff felt would provide maximum petroleum savings with minimum negative economic impact in each of the three sectors (residential, commercial, and commercial transportation). The estimated petroleum savings listed in these tables represent preliminary estimates.

Before describing these potential standby regulations in more detail, an alternative approach to emergency conservation should be mentioned. In the event of an oil embargo, the federal government could mandate a "percentage reduction contingency plan" as described in a recent FEA publication. 1 Under such a plan, each geographic sector would be allocated a certain percentage of petroleum calculated on an arbitrary base period. Officials of the geographic sector would then be free to selcct any combination of measures for coping with the shortage that seemed best suited to the particular situation. After public review of an initial set of standby regulations, FEA reported that the public preferred the "percentage reduction" approach as contrasted with a federal mandate of specific measures that may, or may not, best fit a specific situation. Most state energy office staff who were contacted by ORNL agreed that percentage allocation was more effective and caused less negative public reaction than mandated, uniform measures. Consequently, the first measure listed in each of Tables 3.5, 3.6, and 3.7 refer's to this option. If it were selected, all other measures would be voluntary means of coping.

${ }^{1}$ Report on the Feasibility of Developing an Emergency Percentage Reduction Contingency Plan for Petroleum, Federal Fnergy Administration, June 1977. 
Table 3.5. Emergency measures to reduce petroleum consumption in residential buildings

\begin{tabular}{|c|c|c|c|c|}
\hline \multirow{3}{*}{ Measure } & \multicolumn{4}{|c|}{$\begin{array}{c}\text { Estimated annual energy savings } \\
(\text { trillion of } \mathrm{Btu})^{a}\end{array}$} \\
\hline & \multicolumn{2}{|c|}{ Potential } & \multicolumn{2}{|c|}{$\begin{array}{l}\text { Assumed achievable } \\
\qquad(40 \%) b\end{array}$} \\
\hline & Total & Petroleum & Total & Petroleuin \\
\hline \multicolumn{5}{|l|}{ Wandalos:y: } \\
\hline Allocate \% of supply & \multicolumn{4}{|c|}{ Savings predetermined by $\%$ allocated } \\
\hline \multicolumn{5}{|l|}{ Voluntary: } \\
\hline $\begin{array}{l}\text { Change thermostat setting } \\
68^{\circ} \mathrm{F} \text { winter; } 60^{\circ} \mathrm{F} \text { night } \\
78^{\circ} \mathrm{F} \text { summer }\end{array}$ & $\begin{array}{r}1,000 \\
100\end{array}$ & $\begin{array}{r}350 \\
40\end{array}$ & $\begin{array}{r}400 \\
40\end{array}$ & $\begin{array}{r}140 \\
20\end{array}$ \\
\hline $\begin{array}{l}\text { Set back water temperature } \\
120^{\circ} \mathrm{F}\end{array}$ & 400 & 130 & 160 & 50 \\
\hline $\begin{array}{l}\text { Reduce infiltration } \\
\text { Caulking } \\
\text { Polyethelene sheets, } \\
\text { drapes }\end{array}$ & $\begin{array}{l}300 \\
100\end{array}$ & $\begin{array}{r}-100 \\
30\end{array}$ & $\begin{array}{r}120 \\
40\end{array}$ & $\begin{array}{l}40 \\
10\end{array}$ \\
\hline Tune furnaces & 700 & 250 & 280 & 100 \\
\hline $\begin{aligned} \text { Totals: } & \text { trillion Btu } \\
& \text { bbl/day }\end{aligned}$ & $\begin{array}{r}2,600 \\
1,200,000\end{array}$ & $\begin{array}{r}900 \\
425,000\end{array}$ & $\begin{array}{r}1,040 \\
500,000\end{array}$ & $\begin{array}{r}360 \\
170,000\end{array}$ \\
\hline \multicolumn{5}{|c|}{$\begin{array}{l}\text { Most of the saving ( } 80 \text { to } 90 \% \text { ) accrues in the winter. } \\
b_{\text {Percentage taken from NPC report, but compliance could vary }} \\
\text { iderably. }\end{array}$} \\
\hline $\begin{array}{l}\text { Source: National Petro } \\
\text { irl the United States: } 1974-\end{array}$ & $\begin{array}{l}\text { oleum Counc } \\
-1978, \mathrm{p} . \varepsilon\end{array}$ & $\begin{array}{l}\text { Potential } \\
974 .\end{array}$ & Energy & serv \\
\hline
\end{tabular}


Tablc 3.6. Emergency measures to reduce petroleum. consumption in commercial buildings

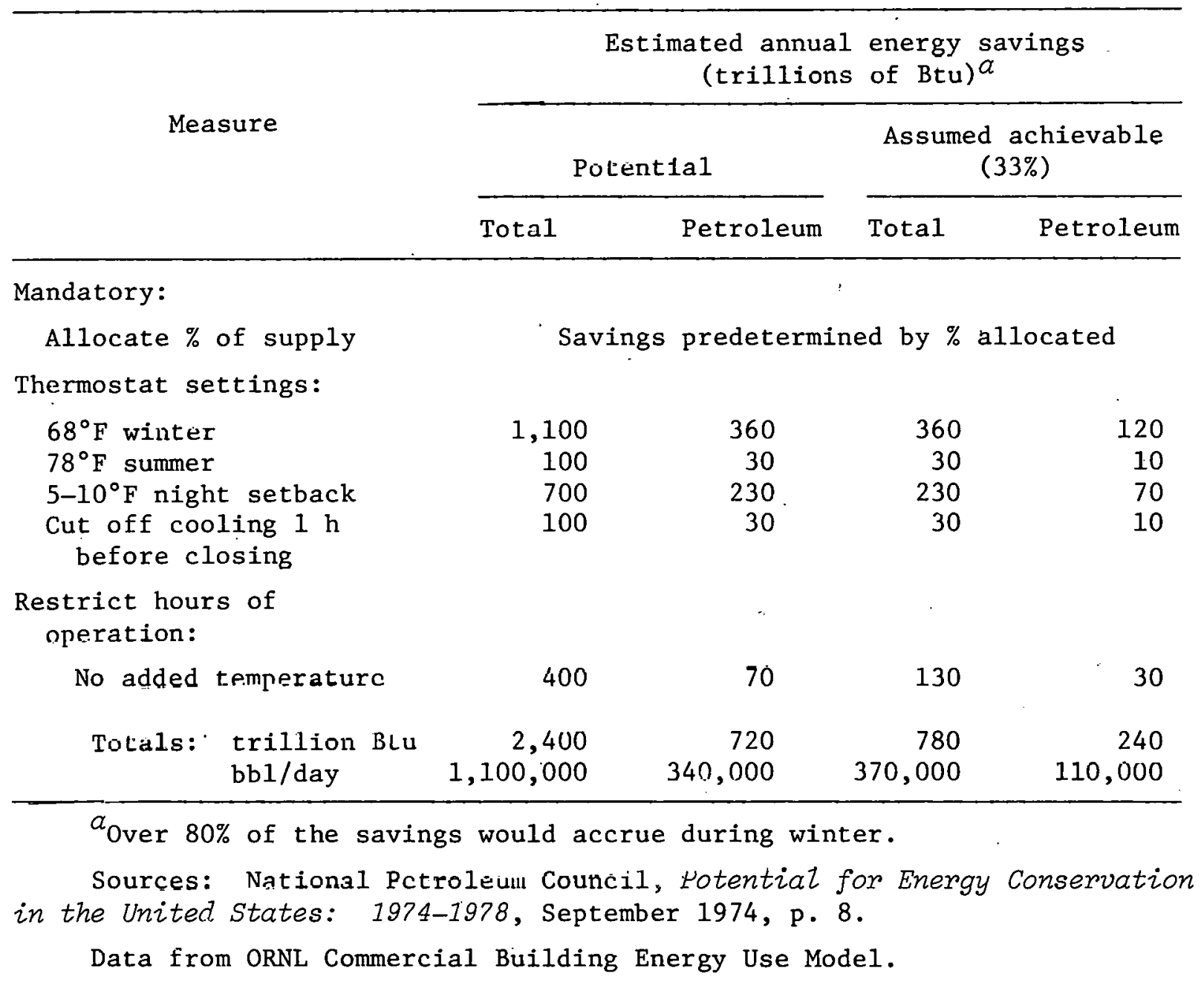


Table 3.7. Emergency measures to reduce petroleum consumption in commercial transportation

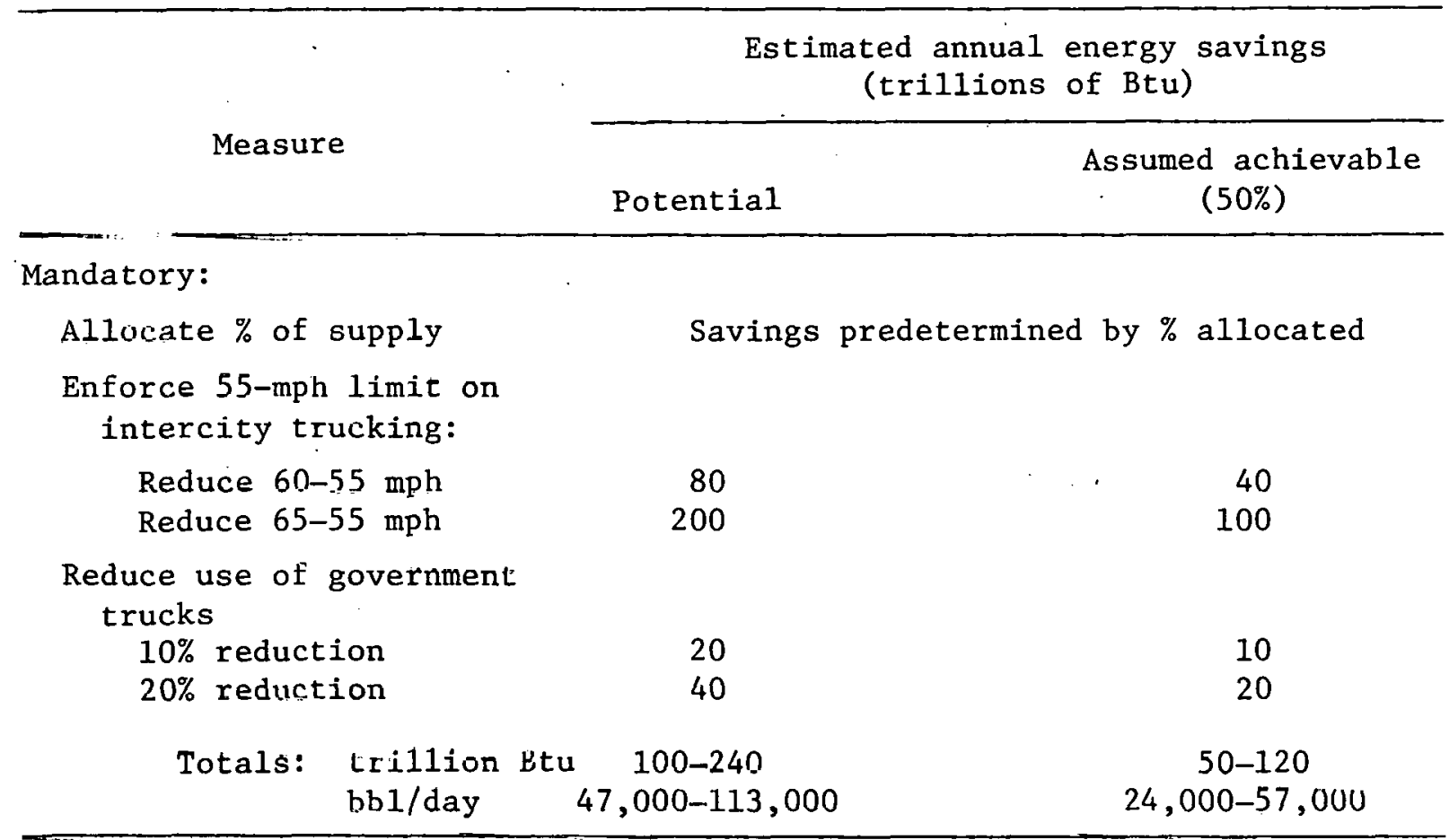

Sources: General Services AdmInlstration, Felez'ul. Motor Vohich.e Fileet Roport, Washington, D.C., July 1976, pp. 16, 26.

Shonka, D. B., Loebl, A. S., Patterson, P. D., Transportation E'nergy Consemation Data Book: Edition 2, Oak Ridge, Tenn., October 1977, p. 24.

Department of Transportation, The Effect of Speed on Truck Fuel Consumption Rates, Washington, D.C., August 1974, p. 14.

Motor Vehicle Manufacturers Association, Motor Vehicle Facts and Figures, 1977, Washington, D.C., 19/i, p. 60 . 1979.

Greene, David, Oak Ridge National Laboratory, personal communication, 
If the percentage reduction approach is not selected, the other measures listed in the tables become candidates for standby regulations. Residential owners could be asked to reduce thermostats, use less hot water, "tighten up the house," and have oil burners tuned. Obviously, these measures could not be enforced and would depend upon voluntary compliance. Total potential petroleum savings, nationwide, would be about 0.9 quad $(425,000 \mathrm{bbl} /$ day $)$ or about $1 / 5$ of all residential petroleum consumption. Assumed compliance is very difficult to judge. Using estimates from the National Petroleum Council of about $40 \%$ compliance, the actual petroleum savings might be less than 0.4 quad $(190,000 \mathrm{bbl} / \mathrm{day})$ or about $9 \%$ of residential petroleum usage. ${ }^{2}$

Commercial buildings have a potential for petroleum savings. Mandated building temperature restrictions in commercial establishments, excluding hotels, motels, and health care facilities, might save about 0.3 quad/year or about $140,000 \mathrm{bbl} /$ day of petroleum. ${ }^{3}$ Restricting the hours of operation of the buildings, along with additional temperature restrictions during hours of closure, might save another 0.1 quad or about $50,000 \mathrm{bbl} /$ day. If the measures were enforced strictly, most of the potential savings $(190,000 \mathrm{bbl} / \mathrm{day})$ could be realized. However, in many regions of the country the high summer building temperatures would be accompanied by high humidity, and this could damage the contents of some commercial bulldings.

Commercial transportation offers only limited opportunities for savings. As trucking companies, airline companies, bus companies, etc., attempt to maximize proftt and minimize cost, the rapidly rising cost of fuel has already brought about many of the short-range measures that

2Title II of the National Energy Act of 1978, referred to as the Residential Conservation Service, will attempt to stimulate a wide range of residential conservation measures. The act requires public utilities in each state to supply energy audits for their customers and help them arrange for implementation of the suggested conservation measures.

${ }^{3}$ The president has recentiy put into operation the "Emergency Building Temperature Restriction Plan," but he has not restricted the hours of operation of commercial buildings. Federal funds to states for enforcement are very limited, so the measure is, in effect, a voluntary on $\epsilon$ at this time. 
might be suggested. For example, airlines have already increased load factors and have reduced cruising speeds. The two measures suggested in Table 3.7 (enforce 55-mph speed limit for intercity trucks and reduce use of government trucks) might save about 0.1 to 0.2 quad (50,000 to $100,000 \mathrm{bb1/day)}$ or about $1 \%$ of truck fuel.

In summary, if all of the measures proposed were put into effect and achieved reasonable compliance, the country might save approximately 1 quad of petroleum or about 2 to $3 \%$ of total U.S. petroleum use in 1977. Such a saving is reasonably significant. 


\section{IN-DEPTH ANALYSIS OF ONE MEASURE: RESTRICTED HOURS OF OPERATION OF COMMERCIAL BUILDINGS}

\subsection{Description of the Measure}

After reviewing the list of possible emergency measures to reduce petroleum consumption compiled by ORNL (see Tables $3.5,3.6,3.7$ ), the Economic Regulatory Administration (ERA) staff selected one of the measures for in-depth study. The analysis was to determine likely petroleum savings, economic and environmental 1mpacts, and government costs associated with restricting the hours of operation of commercial buildings.

The measure to restrict hours of operation of commercial buildings would involve the following regulations:

1. Commercial buildings, defined as wholesale and retall trade, finance, insurance, real estate, business and repair services, amusement and recreation services, and public administration; would be required to limit hours of operation to a maximum of $60 \mathrm{~h} /$ week. Hotels, motels, and health care facilities would be exempted.

2. In order to provide some flexibility, but still be enforceable, several patterns of hours, each totaling $60 \mathrm{hr}$, would be available.

3. During hours of closure, thermostats must be set back to $55^{\circ} \mathrm{F}$ (winter) and cooling systems turned of $\mathrm{f}$ (summer).

The measure could be implemented independently or in conjunction with the Emergency Building Temperature Restriction Plan (EBTRP), which has already been approved by ERA for submission to the secretary of energy. The latter plan mandates thermostat settings of $65^{\circ} \mathrm{F}$ (winter) and $80^{\circ} \mathrm{F}$ (summer).

"Conmercial bulldings," as used above, is a more restrictive definition of that sector than must. This restricted commercial sector consumes only about $2 / 3$ of the energy attributed to the full sector. 


\subsection{Estimated Nationwide Energy Savings of the Measure}

Figure 4.1 is a flow diagram indicating the sources of energy for the commercial sector. Approximately $6000 \times 10^{12}$ Btu of energy will be delivered to end users in the commercial sector during 1980 , and an additional $2700 \times 10^{12} \mathrm{Btu}$ of waste heat will be generated in order to supply the electricity used by the sector. These numbers translate to 2.8 million and 1.3 million barrels of oil equivalent per day respectively.

Energy needs of the commercial sector are met by:

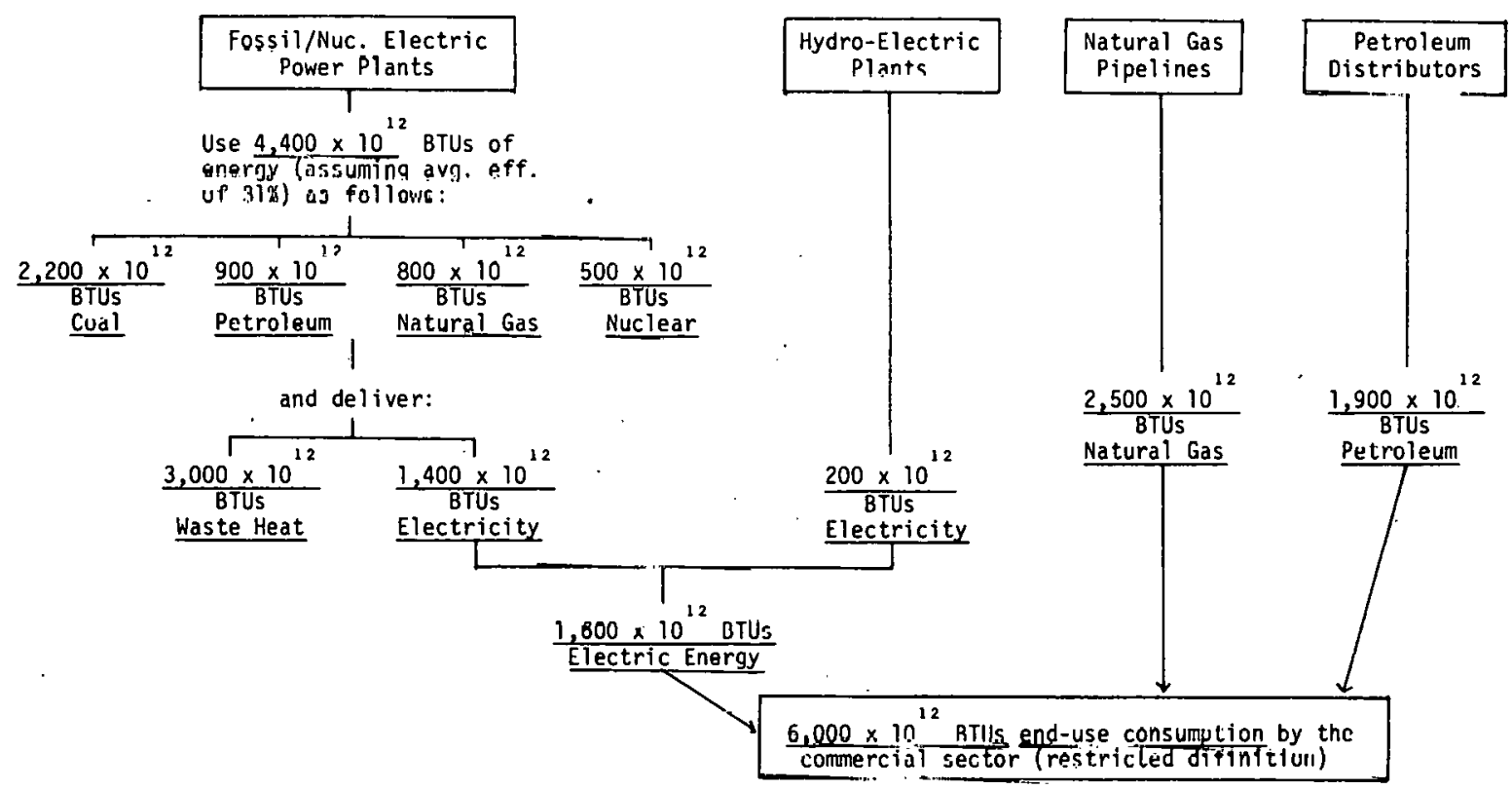

Total energy consumption:

\begin{tabular}{rrrrrr} 
& \multicolumn{1}{c}{ Petroleum } & Natural Gas & Coal & Hydro-Nuclear & Totals \\
\hline X $10^{12}$ BTUs: & 2,800 & 3,300 & 2,200 & 700 & 9,000 \\
bbl/day $:$ & $1,300,000$ & $1,600,000$ & $1,000,000$ & 300,000 & $4,200,000$ \\
\hline
\end{tabular}
Sources: (1) Regional Energy 8alance Statement, 1975, for 1975 baseline;
(2) Corrected to 1978 on basis of Annual Report to Congress, 1978, Eneryy Information Administration, DOE/EIA-0173/2, Volume 2, Pp. 51,77, and 125 .
(3) 1980 commercial consumption assumed to the same as 1978 consumption based on

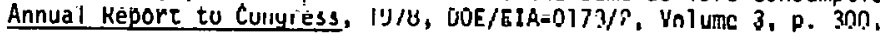

Fig. 4.1. Estimated annual energy use by restricted commercial sector, 1980. Sources: (1) Regional Energy Balance Statement, 1975, for 1975 baseline; (2) Corrected to 1978 on basis of Annual Report to Congress, 1978, Eneryy Information Administration, DOE/EIA-0173/3, Volume 2, pp. 51, 77, and 125; (3) 1980 commercial consumption assumed to be the same as 1978 consumption based on Annual Report to Congress, 1978, DOE/EIA-0173/2, Volume 3, p. 300. 
What part of this energy can be saved by the proposed conservation measure?

Because estimates of energy savings due to the restriction of hours of operation are subject to a number of uncertalnties, this study reports the results of two independent approaches and presents the estimate as a range of possible savings. One approach is to survey recent studies to gather estimates of percentage savings associated with given changes in thermostat settings in commercial buildings. These percentage savings may then be applied to the energy consumption data in Fig. 4.1 to calculate absolute energy savings due to the measure. A second approach is to use the recently developed ORNL Commercial Building Energy Use Model, which can provide estimates of energy savings from reduced heating and cooling for the conditions specified in the restricted hours measure. The results of these two approaches are presented in the following two sections.

\subsubsection{Estimated savings based on recent ASHRAE and NPC studies}

"ASHRAE Standard 90-75: Energy Conservation in New Building Design" was released by ASHRAE's committee on standards in 1975 and was published by the Federal Energy Administration (FEA). Table III-12 of the report provides estimates of energy savings in office buildings and retail stores that could be obtained by simple energy conservation techniques (see Table 4.1).

A $3^{\circ} \mathrm{F}$ change in thermostat settings during winter is estimated to save about $9 \%$ of annual building energy use, and $3^{\circ} \mathrm{F}$ change in summer adds another $3 \%$ savings. Reduced lighting during periods when the building is open and in use could save about $7 \%$ of building energy use.

The National Petroleum Council report, "Potential for Energy Conservation In the U.S.: 1974-1978," provides estimates of possible energy savings in commerrial buildings through conservation measures (see Table 4.2).

A third source of estimated energy savings by means of reduced heating and cooling is provided in exhlbit 2.3 of the EBTRP. A $3^{\circ} \mathrm{F}$ setback $\left(68^{\circ} \mathrm{F}\right.$ to $\left.65^{\circ} \mathrm{F}\right)$ is assumed to give savings of about $9 \%$ in most 
Table 4.1. Energy savings through conservation (ASHRAE)

\begin{tabular}{lcc}
\hline & \multicolumn{1}{c}{$\begin{array}{c}\text { Percent of total annual } \\
\text { energy use saved }\end{array}$} \\
\cline { 2 - 4 } & Office building & Retail store \\
\hline $\begin{array}{c}\text { Thermostat increase } 75^{\circ} \mathrm{F} \text { to } 78^{\circ} \mathrm{F} \\
\quad \text { summer) }\end{array}$ & 3.4 & 3.4 \\
$\begin{array}{c}\text { Thermostat decrease } 75^{\circ} \mathrm{F} \text { to } 72^{\circ} \mathrm{F} \\
\text { (winter) }\end{array}$ & 12.4 & 7.3 \\
$\begin{array}{c}\text { Lighting reduced from } \\
1 \frac{\mathrm{W}}{\mathrm{ft}^{2}} \text { to } 0.8 \frac{\mathrm{W}}{\mathrm{ft} \mathrm{t}^{2}}\end{array}$ & 6.3 & 8.6 \\
\hline
\end{tabular}

Source: An Impact Assessmert of ASIIRAE Stardard 90-75, p. 62, March 1976.

Table 4.2. Energy savings through conservation (National Petrniolim Council)

\begin{tabular}{lc}
\hline \multicolumn{1}{c}{ Measure } & $\begin{array}{c}\text { Percent of total annual } \\
\text { energy use saved }\end{array}$ \\
\hline $\begin{array}{l}\text { Establish a } 10^{\circ} \mathrm{F} \text { night setback from } \\
65^{\circ} \mathrm{F} \text { to } 55^{\circ} \mathrm{F} \text { for commercial } \\
\text { buildingo (winter) }\end{array}$ & 5.7 \\
$\begin{array}{l}\text { Cease cooling of building } 1 \mathrm{hr} \\
\text { before closing (assuming } 78^{\circ} \mathrm{F} \\
\text { setting in oummer) }\end{array}$ & 0.7 \\
$\begin{array}{l}\text { Reduce lighting to minimum } \\
\text { acceptable levels }\end{array}$ & 2.4 \\
\hline
\end{tabular}

Source: Potential for Energy Conservation in the U.S.: 1974-1978, p. 52, National Petroleum Council, Sept. 10, 1974.

regions of the country (winter), and changed thermostat settings of 77 to $80^{\circ} \mathrm{F}$ (in summer) would-give savings of about $5 \%$.

In summary, these studies estimate that thermostat setbacks in winter of $3^{\circ} \mathrm{F}$ in the $70^{\circ} \mathrm{F}$ range provide about 6 to $9 \%$ savings in total annual energy use; increased thermostat settings in summer to about $80^{\circ} \mathrm{F}$ might provide about $3 \%$ savings, but very little is achieved beyond thic; and reduced lighting might add another 2 to $7 \%$. 
For purposes of this study it is assumed:

1. There would be very little added saving in summer beyond setting thermostats to $80^{\circ} \mathrm{F}$.

2. Lighting, during hours of building closure, is already reduced to minimum standards; there would be some small additional savings available, but these will be ignored in the following calculations.

3. Thermostat reduction from $65^{\circ} \mathrm{F}$ to $55^{\circ} \mathrm{F}$ during hours of closure in the heating season does provide potential for savings. If thermostat reduction of $3^{\circ} \mathrm{F}$ in the $70^{\circ} \mathrm{F}$ range reduces annual commercial energy usage by about $9 \%$, a $10^{\circ} \mathrm{F}$ setback from $65^{\circ} \mathrm{F}$ to $55^{\circ} \mathrm{F}$ (lower temperature range) should supply at least an equivalent energy savings - about $9 \%$.

If commercial buildings are restricted to $60 \mathrm{hr} /$ week operation, they must be closed for $108 \mathrm{hr} /$ week, and their thermostats would be set back from $65^{\circ} \mathrm{F}$ to $55^{\circ} \mathrm{F}$ for $2 / 3$ of the week. Furthermore, if a $3^{\circ} \mathrm{F}$ setback saves about $9 \%$ of total annual commercial building energy, a $10^{\circ} \mathrm{F}$ setback, at a lower temperature range, should provide at least an equivalent percentage saving but only for $2 / 3$ of the week. Therefore the total percentage savings of commercial energy should be $2 / 3$ of $9 \%$ or about $6 \%$. (Th1s agrees. with the National Petroleum Council estimate in Table 4.2.) Applying this $6 \%$ savings to the absolute national energy consumption data (1980) for commercial buildings (see Fig. 4.1), energy and petroloum oavings would be possible, as shown in Fig. 4.2. A "bottom line" of savings, by fuel type, is also displayed in Fig. 4.2. It is worth noting again that these estimates involve a series of assumptions, anyone of which may have large error bands. As a check, an independent estimate has been made using an entirely different approach. This estimate is described in the following section.

\subsubsection{Estimated energy savings based on application of ORNL data and models}

The Energy Division of Oak Ridge National Laboratory has assembled a number of energy-related data bases and created models that use theec 
Assuming an even distribution of saving amoung fuel types:

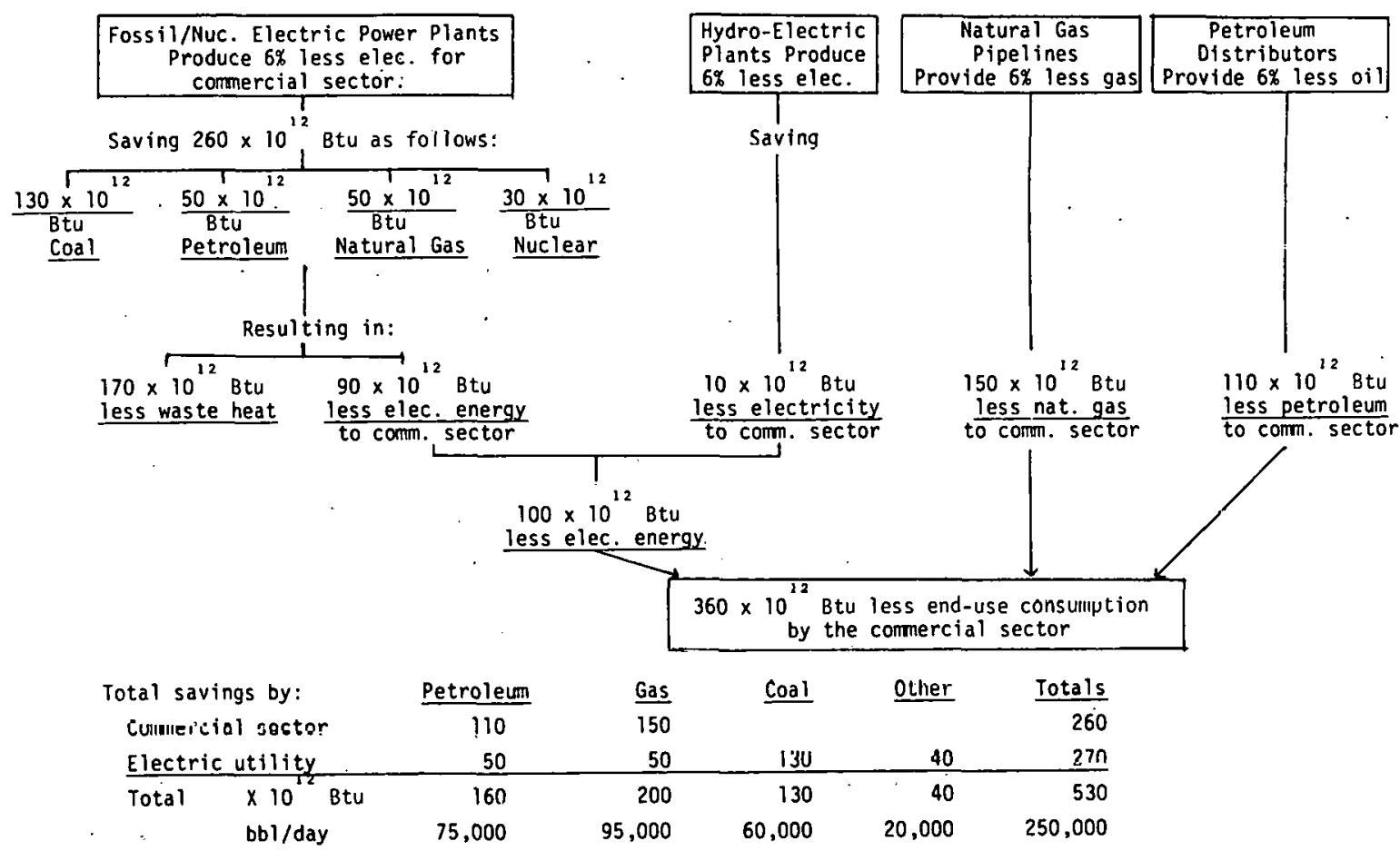

Fig. 4.2. Estimated annual fuel savings from $6 \%$ reduction in enduse energy by the restricted commercial sector, 1980 .

data to estimate consequences of different energy policy options. Among these data bases is one referred to as the Regional Energy Balance Statement (REBS), which shows supply, demand, and net imports of seven fuel types for four final consuming sectors. The 1975 data contain supply and demand information for the United States, census or federal regions, 50 states, and 173 BEAs. ${ }^{4}$ The REBS data were the primary source used in the calculations reported in this section.

A model of commercial building energy use was recentily developed at Oak Ridge National Laboratory. The model forecasts annual cummercial energy use by ten building types, five end uses, and four fuel types. Both economic factors (utilization rate, fuel choice, capital-energy

4. J. B. Mills, P. L. Rice, and D. P. Vogt, Energy Availabilities for State and Local Development: 1975 Data Volume, ORNL/TM-6951 (in preparation). 
substitution) and technological factors (equipment efficiency, thermal characteristics of buildings) are explicitly represented in the model.5,6

Model parameters are derived from engineering and econometric analyses. The model is then validated by simulating commercial energy use over the 1970 through 1975 timc period.

Although the model was not designed originally to provide the kind of energy impact data required by this study, it was possible, but timeconsuming, to introduce the specific parameters of this conservation measure and generate the required information.

The data in Table 4.3 compare the energy use, in absolute numbers and in percentages, for four situation: (1) a base case in which the commercial buildings remain open as they see fit and maintain thermostats at about $72 \pm 2^{\circ} \mathrm{F}$ summer and winter, (2) a case representing implementation of the EBTRP with thermostats at $65^{\circ} \mathrm{F}$ in winter and $80^{\circ} \mathrm{F}$ in summer, (3) a case representing implementation of a 60-hr operation of commercial buildings with thermostats at $55^{\circ} \mathrm{F}$ in winter and no cooling in summer during closed hours, and (4) a case representing implementation of a $40-\mathrm{hr}$ operation of commercial buildings with the same thermostat settings as in item 3 .

From Table 4.3 it is obvious that the major energy saving for all building functions comes about by implementing the EBTRP. This measure. saves about $20 \%$ of energy use for all functions except lighting. Implementing the $60-\mathrm{hr}$ restriction on hours of operation saves some additional space heating and lighting energy. The 40-hr restriction adds very little saving to the 60-hr restriction in space conditioning, but 1t does contribute savings in lighting and mechanical equipment use.

The analysis in the previous section indicated that the implementation of the $60-\mathrm{hr}$ plan might save $6 \%$ of the annual commercial energy usage,

5. NECAP-NASA's Energy-Cost Analysis Progrom, Part I - User's Manual and Part II - Engineering Manual, R. H. Henninger, ed., NASA CR-2590, September 1975 .

6. W. S. Johnson and F. E. Pierce, Energy and Cost Analysis of Commercial Building Shell Characteristics and operating schedules, ORNL/CON-39 (in preparation). 
Table 4.3. Energy use in the commercial sector', by function, for Eour building operating conditions, 1980 projected

\begin{tabular}{|c|c|c|c|c|c|c|c|c|c|c|c|c|}
\hline \multirow{3}{*}{$\begin{array}{c}\begin{array}{c}\text { Condition of } \\
\text { building operation }\end{array} \\
\text { No restrictions: } \\
72 \pm 2^{\circ} \mathrm{F} \text { annual }\end{array}$} & \multicolumn{12}{|c|}{ Energy use by function (quads) } \\
\hline & \multicolumn{2}{|c|}{ Heat } & \multicolumn{2}{|c|}{ Dool } & \multicolumn{2}{|c|}{ Water } & \multicolumn{2}{|c|}{ Light } & \multicolumn{2}{|c|}{ Other } & \multicolumn{2}{|c|}{ Total } \\
\hline & 2.3 & $100 \%$ & 1.5 & $100 \%$ & 0.08 & $100 \%$ & 1.6 & $100 \%$ & 0.58 & $100 \%$ & 6.1 & $100 \%$ \\
\hline $\begin{array}{l}\text { B1dg. temp. restr.: } \\
65^{\circ} \mathrm{F} \text { and } 80^{\circ} \mathrm{F}\end{array}$ & 1.8 & $80 \%$ & 1.2 & $79 \%$ & 0.07 & $80 \%$ & 1.6 & $100 \%$ & 0.47 & $81 \%$ & 5.1 & $83 \%$ \\
\hline $\begin{array}{l}60 \mathrm{hr} \text { open: } \\
55^{\circ} \mathrm{F} \text { and no a.c. } \\
\text { during (closed) } \\
\text { hours }\end{array}$ & $i .6$ & $70 \%$ & 1.1 & $75 \%$ & 0.07 & $80 \%$ & 1.3 & $80 \%$ & 0.47 & $81 \%$ & 4.5 & $75 \%$ \\
\hline $\begin{array}{l}40 \mathrm{hr} \text { open: } \\
55^{\circ} \mathrm{F} \text { and no a.c. } \\
\text { during (closed) } \\
\text { hours }\end{array}$ & 1.6 & $70 \%$ & i.:- & $73 \%$ & 0.07 & $80 \%$ & 1.1 & $68 \%$ & 0.40 & $69 \%$ & 4.3 & $70 \%$ \\
\hline
\end{tabular}

Source: ORN- Commercial Building Energy Jse Model. 
based on space heating saving. From analysis of the ORNL energy use model, the corresponding saving would be less:

$$
\frac{0.226 \text { quads (heating energy saved) }}{6.053 \text { quads (total annual energy used) }}=\begin{gathered}
4 \% \text { saving of annual energy } \\
\text { use. }
\end{gathered}
$$

The model, therefore, provides a more conservative estimate of energy saving ( 4 vs $6 \%$ ).

Using this more conservative $4 \%$ saving, the fuel savings estimates in Fig. 4.2 would be reduced to $2 / 3$ of the original values:

\begin{tabular}{|c|c|c|}
\hline $\begin{array}{l}\text { Petroleum } \\
\text { saved }\end{array}$ & $\begin{array}{c}\text { Natural gas } \\
\text { saved }\end{array}$ & $\begin{array}{l}\text { Other fuels } \\
\text { saved }\end{array}$ \\
\hline $\begin{array}{c}110 \times 10^{12} \mathrm{Btu} / \text { year } \\
(50,000 \mathrm{bbl} / \mathrm{day})\end{array}$ & $\begin{array}{c}130 \times 10^{12} \mathrm{Btu} / \text { year } \\
(65,000 \mathrm{bbl} / \text { day })\end{array}$ & $\begin{array}{c}110 \times 10^{12} \mathrm{Btu} / \text { year } \\
(55,000 \mathrm{bb} 1 / \text { day })\end{array}$ \\
\hline & $\begin{array}{r}\text { Total energy saved } \\
350 \times 10^{12} \mathrm{Btu} / \text { year } \\
(170,000 \mathrm{bbl} / \text { day })\end{array}$ & \\
\hline
\end{tabular}

4.2.2.1 Alternative methods of implementing the measure. The calculations reported in the preceding section assumed that the measure to restrict houss of operation of commercial buildings was implemented as an "add on" to the EBTRP. It' assumed the EBTRP was already in operation, restricting temperatures to $65^{\circ} \mathrm{F}$ (winter) and $80^{\circ} \mathrm{F}$ (summer). The new measure would restrict hours of operation of commercial buildings to $60 \mathrm{hr} /$ week and further restrict temperatures to $55^{\circ} \mathrm{F}$ (winter) and no space conditioning (summer) during hours of closure.

ERA staff requested that estimates of energy savings be made for.. three alternative methods of implementing the restricted hours of operation.

\section{Alternative 1. Assume:}

- EBTRP is not in operation;

- commercial buildings are restricted to $60 \mathrm{hr} /$ week opening;

- there are no temperature restrictions - the building temperatures would be set at $72^{\circ} \mathrm{F}$ for $24 \mathrm{hr} /$ day. 
The energy savings for this case represent those attributcd simply to restricting hours of operation with no accompanying temperature restrictions. The savings would be those attributed to less lighting and less use of ventilating and mechanical equipment. From Appendix Table E-1, the "normal" or median operation of the various classes of commercial buildings is about $72 \mathrm{hr} /$ week. A restriction to $60 \mathrm{hr} /$ week represents a reduction of $1 / 6$ in "open" time and therefore should contribute a savings of about $1 / 6$ of total lighting and mechanical and ventilating use. (This assumes there is very little lighting or ventilating during hours of closure.) Assuming that lighting and mechanfcal equip... ment are electrically powered, the savings would amount to about 175,000 to 250,000 bbl/day dislituted as follows:

$\begin{array}{lr}\text { Petroleum } & 45,000-65,000 \mathrm{bbl} / \mathrm{day} \\ \text { Natural gas } & 35,000-50,000 \mathrm{bbl} / \mathrm{day} \\ \text { Other } & 95,000-135,000 \mathrm{bbl} / \mathrm{day} \\ \quad \text { Total } & 175,000-250,000 \mathrm{bbl} / \mathrm{day}\end{array}$

Allerlalive 2: Mocums:

- EBTRP is not in operation;

- huuss of opcration of sommercial bulluings arc not restricted;

- building temperatures are nul lestricecd whin open but nro restricted when closed to $55^{\circ} \mathrm{F}$ (winter) and no space conditioning (summer).

Energy savings for this case represent those brought about by severe temperature restrictions when the buildings are normally closed, but there are no mandated hours of closing nor temperature reslrictions during "open" hours. The normal average hours of closure for commerc1a1 buildings is $96 \mathrm{hr} /$ week or $57 \%$ of the time. The savings would be est1mated, therefore, as $57 \%$ of those achieved by the EBTRP plus $96 / 108$ or $89 \%$ of those achieved by the added setbacks for the restricted hours of 
operation plan (see Table 4.3). The estimated energy savings would be about 450,000 to $600,000 \mathrm{bbI} /$ day distributed as follows:

$\begin{array}{ll}\text { Petroleum } & 160,000-210,000 \mathrm{bbl} / \mathrm{day} \\ \text { Natural gas } & 170,000-230,000 \mathrm{bb} 1 / \text { day } \\ \text { Other } & 120,000-160,000 \mathrm{bbl} / \mathrm{day} \\ \quad \text { Total } & 450,000-600,000 \mathrm{bbl} / \mathrm{day}\end{array}$

Alternative 3. Assume:

- EBTRP is in operation $\left(65^{\circ} \mathrm{F}\right.$ winter and $80^{\circ} \mathrm{F}$ summer);

- hours of operation for commercial buildings are not restricted;

- during hours of normal closure the temperatures are further restricted to $55^{\circ} \mathrm{F}$ (winter) and no space conditioning (summer).

This alternative represents an "add on" of the temperature restrictions of the original measure to the EBTRP without restricting the hours of operation of the buildings. The energy saving estimates are similar to those for the original measure except that the added temperature restrictions would be in effect for only $96 \mathrm{hr} /$ week rather than $108 \mathrm{hr} /$ week. The savings, therefore, would amount to $96 / 108$ or $89 \%$ of those reported for the original measure:

$\begin{array}{lc}\text { Petroleum } & 50,000-75,000 \mathrm{bbl} / \mathrm{day} \\ \text { Natural gas } & 55,000-85,000 \mathrm{bb} 1 / \mathrm{day} \\ \text { Other } & 40,000-60,000 \mathrm{bbl} / \mathrm{day} \\ \quad \text { Total } & 145,000-220,000 \mathrm{bbl} / \mathrm{day}\end{array}$

\subsubsection{Estimated energy savings for selected regions of the} country. Table 3.4 revealed the substantial variation in patterns of energy use by the commercial sector in different regions of the country. The purpose of this section is to investigate these regional variations in more detail and to estimate energy savings for several regions.

Federal regions I, IV, and VI were selected for detailed analysis (see Fig. 1.1). These three regions were chosen because they differ markedly in climate and in patterns of basic fuel use. For each region, an estimate may be made of possible fuel savings brought about by implementing the $60-\mathrm{hr}$ restriction on operation of commercial buildings, 
assuming the EBTRP has already been implemented. The calculations for three federal regions follow:

\section{Federal region I}

1. The 1975 pattern of basic fuel use for the restricted commercial sector (as defined for this measure) for federal region I may be obtained from the REBS data (1012 Btu):

Direct use

Elec. gentealiui (inc. waste heat)

Totals

$\begin{array}{rrrrr}\text { Coal } & \frac{\text { Oil }}{1} & \text { Gas } & \text { Other } & \text { Total } \\ 13 & 358 & 52 & & 411 \\ 14 & 488 & 1 & 17 & 161 \\ & & 53 & 17 & 572\end{array}$

2. Since the energy saving is to be calculated for 1980 , it is necessary to adjust the above figures for 1975-80 changes. The EIA Annual Report to Congress for 1978, Vol. II, pp. 50, 77, 93, and 125 provides $1975-78$ increments in use of various fuels by the sector. Also, Vol. III of the EIA report, p. 300, states, "The commercial sector is the only major energy-consuming sector in which the level of energy consumed in one of the projection periods, 1977 to 1985, is below the level of energy consumption in 1977." For purposcs of thic estimate, the commerrial sector in 1978 energy use was assumed to plateau through 1980. Applying the 1975-78 adjustment factors to the above data and assuming that the result also holds for 1980 results in the following (1012 Btu):

\begin{tabular}{|c|c|c|c|c|c|c|}
\hline & & Sna 1 & oi.1. & Gas & Other & Total \\
\hline Direct use & & 1 & 391 & 56 & & 448 \\
\hline $\begin{array}{l}\text { Elec. gener } \\
\text { (incl. wa }\end{array}$ & $\begin{array}{l}\text { n } \\
\text { heat) }\end{array}$ & 15 & 148 & 1 & 19 & 183 \\
\hline Totals & $\mathrm{N}$ & 16 & 539 & 57 & 19 & 631 \\
\hline & $\%$ & 2 & 85 & 9 & 3 & 100 \\
\hline
\end{tabular}

3. The ORNL Commercial Building Energy Use Model supplied information regarding the pattern of energy consumption, by function, for region $I$. It also supplied estimates of percentage energy savings 
caused by implementing the $60-\mathrm{hr}$ restriction plan in conjunction with the EBTRP:

Function \% of commercial sector annual energy use, region I Space heating 57

Space cooling

9

Water heating 5

Lighting 20

Other 9 Total 100

The percentage energy savings attributed to the 60-hr restriction above those obtained by the EBTRP was:

$9.5 \%$ saving of annual space heating energy
$5 \%$ saving of annual space cooling energy

4. Combining the above information, the total estimated energy saving during 1980 attributed to the conservative measure would be $[(0.095)(0.57)+(0.05)(0.09)]\left(631 \times 10^{12} \mathrm{Btu}\right)=37 \times 10^{12} \mathrm{Btu}$, and if this saved energy is distributed in the same fasion as in the total energy use pattern (see item 2 above), the fuel saved in 1980 in federal region I would be:

\begin{tabular}{lrrrr} 
& \multicolumn{2}{c}{ Savings } & bbl/day & Percent \\
Fuel & $\times 10^{12}$ Btu' & 400 & -2 \\
Coal & $(0.02)(3 \overline{7})=$ & 1 & 15,000 & 85 \\
Oil & $(0.85)(37)=32$ & 1,500 & 9 \\
Gas & $(0.09)(37)=3$ & 500 & 3 \\
Other & $(0.03)(37)=1$ & 17,400 & 100 \\
Totals & & & & \\
& & &
\end{tabular}

\section{Federal region IV}

1980 fuel cuilsumption, commercial sector, $10^{12}$ Btu: 


$\begin{array}{rrrrrr} & \text { Coal } & \underline{\text { Oil }} & \text { Gas } & \underline{\text { Other }} & \text { Total } \\ \mathrm{N} & 490 & 339 & 291 & 52 & 1172 \\ \% & .42 & 29 & 25 & 4 & 100\end{array}$

Percentage of commercial sector annual energy use by function:

\begin{tabular}{lr} 
Space heating & 33 \\
Space cooling & 28 \\
Water heating & 1 \\
Lighting & 26 \\
Other & 12 \\
\multicolumn{1}{c}{ Total } & 100
\end{tabular}

Potential savings attributed to the 60-hr restriction above those obtained by the EBTRP were:

$11 \%$ saving of annual space heating energy $4.5 \%$ saving of annual space cooling energy

Esstimated fuel savingo in federal region IV in 1980 would be:

\begin{tabular}{lrrr}
\multicolumn{1}{c}{ Fuel } & \multicolumn{2}{c}{ Savings } & \\
Coal & $\times 10^{12}$ Btu & bbl/day & Percent \\
Oil & 24 & 11,300 & 42 \\
Gas & 17 & 7,800 & 29 \\
Other & 14 & 6,700 & 25 \\
$\quad$ Totals & 2 & 1,000 & 4 \\
& 57 & 26,800 & 100
\end{tabular}

\section{Federà region VI}

1980 fuel consumption, commercial sector, $10^{12}$ Btu:

$\begin{array}{rrrrrr} & \text { Coal } & \text { Oil } & \text { Gas } & \text { Other } & \text { Total } \\ \mathbf{N} & 43 & 91 & 949 & 11 & 1094 \\ \% & 4 & 8 & 87 & 1 & 100\end{array}$


Percentage of commercial sector annual energy use by function:

\begin{tabular}{lr} 
Space heating & 31 \\
Space cooling & 36 \\
Water heating & \\
Lighting & 23 \\
Other & 10 \\
\multicolumn{1}{c}{ Total } & 100
\end{tabular}

Potential savings attributed to the 60 -hr restriction plan above those obtained by the EBTRP were:

$10.5 \%$ saving of annual space heating energy

$4 \%$ saving of annual space cooling energy

Estimated fuel savings in federal region VI in 1980 would be:

\begin{tabular}{lrrr}
\multicolumn{2}{c}{ Savings } & & \\
Fuel & $\times 10^{12}$ Btu & bbl/day & Percent \\
\hline Coal & 2 & 1,000 & 4 \\
Oil & 4 & 2,000 & 8 \\
Gas & 44 & 21,000 & 87 \\
Other & 1 & & 1 \\
Totals & 51 & 24,000 & 100
\end{tabular}

\subsubsection{Summary}

The studies described in the preceding sections provide the following "bottom line" results:

- Implementation of the 60-hr restriction of operation of commercial buildings would save some fuel over and above that saved by the EBTRP. The added fuel savings would fall within the following ranges:

$$
\begin{array}{lr}
\text { Petroleum } & 50,000-75,000 \mathrm{bbl} / \mathrm{day} \\
\text { Natural gas } & 65,000-95,000 \mathrm{bb} 1 / \mathrm{day} \\
\text { Other } & 55,000-80,000 \mathrm{bbl} / \mathrm{day} \\
\quad \text { Total } & 170,000-250,000 \mathrm{bbl} / \mathrm{day}
\end{array}
$$


These savings represent 4 to $6 \%$ of annual energy use by the commercial sector. The above estimate assumes $100 \%$ compliance rates. The estimates should be reduced if enforcement and compliance are low.

- Implementation of the 40-hr restriction measures saves very little additional space conditioning energy beyond that saved by the $60-\mathrm{hr}$ restriction measure.

- Analysis of three alternative methods of defining and implementing the emergency measure yields estimates of total energy savings that vary from about $200,000 \mathrm{bbl} /$ day to about $500,000 \mathrm{bbl} / \mathrm{day}$. The savings depend upon the degree to which building temperature settings and building hours are regulated and on whether the EBTRP is implemented in conjunction with the restricted hours of operation.

- As one would expect, the commercial sectors in the various regions vary markedly in terms of fuel use for different functions:

Estimated percent of commercial sector annual energy use by funcliun

\begin{tabular}{rcccccc}
$\begin{array}{r}\text { Ferpra1 } \\
\text { region }\end{array}$ & $\begin{array}{c}\text { Space } \\
\text { heating }\end{array}$ & $\begin{array}{c}\text { Space } \\
\text { ronling }\end{array}$ & $\begin{array}{c}\text { Water } \\
\text { heating }\end{array}$ & Light & Other & Total \\
\hline I & 57 & 9 & 5 & 20 & 9 & 100 \\
IV & 33 & 28 & 1 & 26 & 12 & 100 \\
VI & 31 & 36 & & 23 & 10 & 100
\end{tabular}

- Direct petroleum savings derived from implementing the 60-hr restriction measure as an "add on" to the EBTRP would vary greatly from region to region of the country. Federal regions $I$ and II are large users of petroleum and could save appreciable amounts through conservation. Many of the other federal regions use very little petroleum and consequently have 11ttle potential for saving. These latter regions would probably question the logic of implementing restrictions that demonstrably could not conserve the scarce 
commodity. Special studies of three federal regions illustrate these variations in patterns of fuel savings attributed to the 60-hr measure:

\begin{tabular}{|c|c|c|c|c|c|c|c|c|c|c|}
\hline \multirow{3}{*}{$\begin{array}{r}\text { Federa1 } \\
\text { region }\end{array}$} & \multicolumn{10}{|c|}{ Estimated fuel saving by type of fuel } \\
\hline & \multicolumn{2}{|c|}{ Coal } & \multicolumn{2}{|c|}{ Petroleum } & \multicolumn{2}{|l|}{ Gas } & \multicolumn{2}{|c|}{ Other } & \multicolumn{2}{|c|}{ Total } \\
\hline & bb1/day & $\%$ & $\mathrm{bbl} / \mathrm{day}$ & $\%$ & bbl/day & $\%$ & $\mathrm{bb} 1 /$ day & $\%$ & $\mathrm{bbl} / \mathrm{day}$ & $\%$ \\
\hline I & 400 & 2 & 15,000 & 85 & 1,500 & 9 & 500 & 3 & 17,400 & 100 \\
\hline IV & 11,300 & 42 & 7,800 & 29 & 6,700 & 25 & 1000 & 4 & 26,800 & 100 \\
\hline VI & 1,000 & 4 & 2,000 & 8 & 21,000 & 87 & & $<1$ & 24,000 & 100 \\
\hline
\end{tabular}

\subsection{Economic Impacts}

\subsubsection{Introduction and overview of results}

The economic impacts of regulation restricting operating hours of commercial establishments are described in this section. Reductions in operating hours are related to reductions in man-hours, wages, and sales in the sector. Impacts of these reductions on aggregate economic activity are computed. Regional impacts on selected regions are also analyzed and compared.

The study's assumptions are presented in Sect. 4.3 .2 and the analytic approach in Appendixes D and E. A summary of the major assumptions and their effects follows:

- The proposed regulation reduces the commercial sector's operating time to 40 to $60 \mathrm{hr} /$ week for a maximum of one year.

- The energy savings obtained from implementing the regulation falls between 170,000 to $250,000 \mathrm{bbl} /$ day oil equivalent.

- The energy saved in the commercial occtor lo used in the manufacturing sector to partially offset the assumed shortfall of 1.6 million bbl/day in the economy.

- Energy prices increase to reflect supply shortages.

Aggregate economic impacts were determined as deviations from a baseline economy which was derived using the Data Resources Inc. macrneconomic 
model (see Appendixes $D$ and $E$ ). There are few or no empirical data relating changes in commercial sector operating hours to changes in commercial sector. Consequently, the impacts on these variables from reduced operating hours could range from no effect to a proportional decline (i.e., a $1 \%$ reduction in operating hours is associated with a $1 \%$ reduction in the variables cited). The strict proportionality assumption represents a "worst case" situation and is perhaps extreme. On the other hand, an assumption of no impacts on any of the variables is equally unlikely. The approach taken in this analysis was to consider incremental levels of proportionality between 0 and 1 and to identify the level at which significant impacts on the overall economy become apparent. Significant adverse impacts on economic activity, described herein, are evident at a proportionality factor of 0.25 , even under lhe assumption that the commercial sector incurs no loss in sales of goods and services because of the regulation (i.e., when a $1 \%$ reduction in operating hours is associated with a $0.25 \%$ reduction only in man-hours and wages respectively). Including a declining sales assumption further aggravates these adverse economic impacts. In either case these impacts occur notwithstanding the conservative value of the proportionality factor. 7

'able 4.4 presenls regulalion-induced aggregatc economie impacts for the 40- and 60-hr cases with a proportionality factor of 0.25 . Two sets of results are shown for each case. The first result is based on the assumption that only man-hours and wages in the cummercial sector arc affected by the regulation (i.e., consumer purchasing patterns are assumed to adjust to reduced operating hours, resulting in little or no loss in sales). The second result shows the additional impacts resulting from considering a loss in sales in the sector (i.e., consumer purchasing patterns are assumed not to fully adjust to reduced operating hours resulting in a decline in sales).

7. Williams, G. L., Vice-President, Operations Division, National Retail Merchants Association, personal communication and unpublished reports of NRMA. 
Table 4.4. Aggregate economic impacts on selected variables relative to baseline quarterly averages ${ }^{a}$

\begin{tabular}{|c|c|c|c|c|}
\hline \multirow[b]{3}{*}{$\begin{array}{l}\text { Percent change } \\
\text { in variables }\end{array}$} & \multicolumn{4}{|c|}{ Regulation } \\
\hline & \multicolumn{2}{|c|}{ 60-hr week } & \multicolumn{2}{|c|}{ 40-hr week } \\
\hline & $\begin{array}{c}\text { Without loss } \\
\text { of sales }\end{array}$ & $\begin{array}{l}\text { With loss } \\
\text { of sales } b\end{array}$ & $\begin{array}{l}\text { Without loss } \\
\text { of sales }\end{array}$ & $\begin{array}{l}\text { With loss } \\
\text { of sales } b\end{array}$ \\
\hline Real GNP & -0.03 & -0.59 & -0.16 & -1.91 \\
\hline $\begin{array}{l}\text { Real personal con- } \\
\text { sumption } \\
\text { expenditures }\end{array}$ & -0.15 & -1.02 & -0.36 & -3.00 \\
\hline $\begin{array}{l}\text { Real gross private } \\
\text { domestic fixed } \\
\text { investment }\end{array}$ & 0.00 & 0.37 & 0.08 & -1.26 \\
\hline $\begin{array}{l}\text { Real changes in } \\
\text { business } \\
\text { inventories }\end{array}$ & +4.90 & +6.40 & +6.40 & +5.17 \\
\hline $\begin{array}{l}\text { Real disposable } \\
\text { personal income }\end{array}$ & -0.30 & -0.74 & -0.73 & -2.14 \\
\hline $\begin{array}{l}\text { Unemployment ratec } \\
\text { equivalent (per- } \\
\text { centage point } \\
\text { change) }\end{array}$ & +0.28 & +0.69 & +0.68 & +1.99 \\
\hline $\begin{array}{l}\text { Consumer price } \\
\text { index: urban }\end{array}$ & 0.00 & -0.02 & 0.00 & -0.08 \\
\hline \multicolumn{5}{|c|}{$\begin{array}{l}a_{\text {Baseline economy is defined to include shortfall in crude }} \\
\text { supplies of } 1.6 \text { million bbl/day and restrictions on temperatures in } \\
\text { selected buildings (Appendixes } \mathrm{D} \text { and } \mathrm{E}) \text {. The averages are computed } \\
\text { over the four quarters ( } 1980: 4 \text { to } 1981: 3 \text { ) during which regulation is } \\
\text { in effect. } \\
b_{\text {Represents cases where loss in commercial sector sales is }} \\
\text { assumed in addition to the reductions in man-hours and wages in the } \\
\text { sector. } \\
\qquad c_{\text {The baseline average unemplnyment rate is } 6.5 \% \text {. Table values }} \\
\text { may be added to this rate to obtain the total unemployment rate with } \\
\text { regulation. }\end{array}$} \\
\hline
\end{tabular}


Table 4.4 indicates the following:

- The level of economic activity is adversely affected by the regulation even under conservative assumptions regarding effects of reduced operating hours on commercial operations.

- The negative impacts on the selected economic variables worsen as the regulation becomes more restrictive.

- The declining sales assumption increases the negative impact in both the 40- and 60-hr cases.

- Real disposable income and consumption are reduced substantially.

- The unemployment rate incroasoc elgnificantly.

- Business inventories rise as production patterns lag changes in consugumption.

- Inflationary pressures ease as aggregate demand falls.

Selected economic impacts of the regulation were analyzed for regions I, IV, and VI described earlier. The impacts were determined considering regional variations in employment, wages, and sales in commercial establishments and are described in detail in sect. 4.3.2. All three regions are adversely impacted by the regulation in proportion to the extent of their commercial sector activities. On an absolute basis, region IV would suffer the greatest loss in income and employment for all cases considered and region 1 the least. On a relative basis (1.e., 1n relation to each region's baseline economic activity) the impacts on income and employment were found to be similar to those shown nationally. These results are shown in Tables 4.5 and 4.6 .

\subsubsection{Factors influencing economy under regulation}

4.3.2.1 Commercial sector. Establishments in the commercial sector engage in activities which can be broadly described within the following Standard Industrial Classification (SIC) divisions: 
Table 4.5. Regulation-induced losses in regional disposable income - 1980:4 through 1981:1

(billions of current $\$$ )

\begin{tabular}{|c|c|c|c|c|c|}
\hline \multirow[b]{3}{*}{ Region } & \multicolumn{5}{|c|}{ Impacts } \\
\hline & \multirow{2}{*}{$\begin{array}{c}\text { Disposable } \\
\text { income } \\
\text { (baseline) }\end{array}$} & \multicolumn{2}{|c|}{ 60-hI week } & \multicolumn{2}{|c|}{ 40-hr week } \\
\hline & & $\begin{array}{c}\text { Without } \\
\text { sales loss }\end{array}$ & $\begin{array}{c}\text { With sales } \\
\text { loss }\end{array}$ & $\begin{array}{c}\text { Without } \\
\text { sales loss }\end{array}$ & $\begin{array}{c}\text { With sales } \\
\text { loss }\end{array}$ \\
\hline U.S. & 1972.3 & 5.87 & 14.66 & 14.48 & 42.16 \\
\hline Region I & 108.5 & 0.32 & 0.81 & 0.80 & 2.32 \\
\hline Region IV & 293.8 & 0.88 & 2.19 & 2.16 & 6.29 \\
\hline Region VI & 209.0 & 0.62 & 1.56 & 1.54 & 4.48 \\
\hline
\end{tabular}

Table 4.6. Regulation-induced increases in regional unemployment and resultant unemployment rates - 1980:4 through 1981:3

\begin{tabular}{|c|c|c|c|c|c|}
\hline \multirow[b]{3}{*}{ Region } & \multicolumn{5}{|c|}{ Impacts } \\
\hline & \multirow{2}{*}{$\begin{array}{c}\text { Baseline } \\
\text { unemployment } \\
\text { level and } \\
\text { rate }\end{array}$} & \multicolumn{2}{|c|}{ 60-hr week } & \multicolumn{2}{|c|}{ 40-hr week } \\
\hline & & $\begin{array}{c}\text { Without } \\
\text { sales loss }\end{array}$ & $\begin{array}{l}\text { With sales } \\
\text { loss }\end{array}$ & $\begin{array}{c}\text { Without } \\
\text { sales loss }\end{array}$ & $\begin{array}{c}\text { With sales } \\
\text { Ioss }\end{array}$ \\
\hline U.S. & $\begin{array}{c}7,000,000 \\
(6.50 \%)\end{array}$ & $\begin{array}{l}299,500 \\
(6.78 \%)\end{array}$ & $\begin{array}{l}741,000 \\
(7.19 \%)\end{array}$ & $\begin{array}{l}734,000 \\
(7.18 \%)\end{array}$ & $\begin{array}{c}2 ; 133,000 \\
(8.49 \%)\end{array}$ \\
\hline Region I & $\begin{array}{l}414,000 \\
(6.55 \%)\end{array}$ & $\begin{array}{r}17,580 \\
(6.82 \%)\end{array}$ & $\begin{array}{r}43,900 \\
(7.24 \%)\end{array}$ & $\begin{array}{r}43,400 \\
(7.23 \%)\end{array}$ & $\begin{array}{l}126,300 \\
(8.54 \%)\end{array}$ \\
\hline Region IV & $\begin{array}{c}1,235,000 \\
(7.06 \%)\end{array}$ & $\begin{array}{r}48,400 \\
(7.33 \%)\end{array}$ & $\begin{array}{l}120,900 \\
(7.75 \%)\end{array}$ & $\begin{array}{l}119,500 \\
(7.74 \%)\end{array}$ & $\begin{array}{l}347,700 \\
(9.04 \%)\end{array}$ \\
\hline Region VI & $\begin{array}{l}528,000 \\
(4.44 \%)\end{array}$ & $\begin{array}{r}33,800 \\
(4.73 \%)\end{array}$ & $\begin{array}{r}84,500 \\
(5.15 \%)\end{array}$ & $\begin{array}{r}83,500 \\
(5.14 \%)\end{array}$ & $\begin{array}{l}243,000 \\
(6.49 \%)\end{array}$ \\
\hline
\end{tabular}




\section{SIC division}

E

F

G

$\mathrm{H}$

I

$\mathrm{J}$

\section{Description}

Transportation, communication, electricity, gas, and sanitary services (excluding actual generation and transportation activities)

Wholesale trade

Retail trade

Finance, insurance, and real estate Services

Public administration

The imposition of a 40- to $60-\mathrm{hr} /$ week limit on operating Llut can be expected to affect significantly the operating patterns of many establishments in the retail trade and services divisions and to have 4 lesser or negligible effect on those in the other SIC divisions (Table 4.7).

The retail trade division includes establishments that sell merchandise for personal or household consumption and render services incidental to the sale of the goods. Establishments in the services division are engaged in providing a wide variety of services for individuals, businesses, government establishments, and other organizations. Many of these establishments would be required to cut back if regulations were imposed. Establishments such as hotels and motels, hospitalo, and nursing homes are assumed to be exempt from the regulations.

of the 12 categories of business establishments listed in Table 4.7, only seven would be affected if time of operation is restricted to $60 \mathrm{hr} /$ week, because only these currently operate for longer hours. In particular, gasoline service stations that are open from 7:00 AM to $10 \mathrm{PM}$, seven days per week, would be especially hard hit. Under the $60-\mathrm{hr} /$ week restriction, these service stations would reduce their hours of operation by approximately $43 \%$, while for the $40-\mathrm{hr} /$ week case, hours of operation would be reduced by $62 \%$.

Retail and service establishments that are less affected by the regulation include general merchandise, food, apparel and accessories, and personal services. Each of these establishment's operating hours would reduce by about $17 \%$ under the $60-\mathrm{hr} /$ week restriction, and by about $44 \%$ under the more stringent $40 \mathrm{hr} /$ week restriction. 
Table 4.7. Commercial sector establishments affected by regulation limiting hours of operation $\alpha$

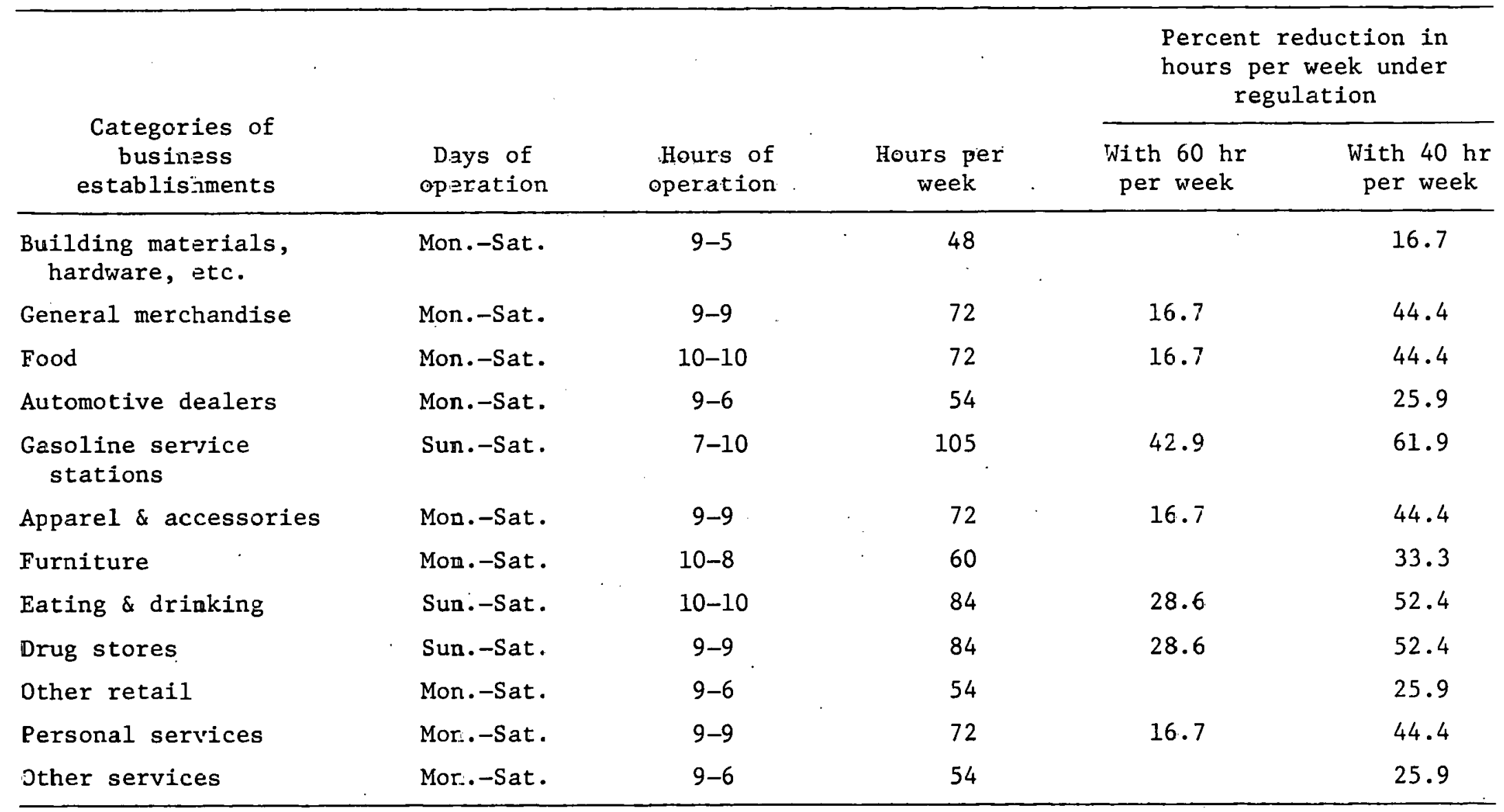

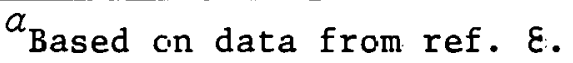

8. A Study of the Impact of Feduced Retaiz Store Operating Hours on Sales, Employment, Economic Con centration, and Energy Consumption, Energy Resources Co., NTIS Doc. No. PB-243579, October 1974, p. 5-17. 
4.3.2.2 Income and employment effect. A reduction in operating hours has income and employment effects that are induced by a reduction in personnel requirements for operating establishments. Because of capacity constraints in many establishments, they can only effectively use a limited number of employees during any given period. Thus a reduction in operating hours is likely to produce an excess supply of labor in the commercial sector.

Table 4.8 shows that employees of eating and drinking establishments constitute a larger proportion of the employed in the commercial sector than that of any other establishments considered. Table 4.2 slows that these establishments would experience a reduction in work hours of about $20 \%$ when restricted to operate for $60 \mathrm{hr} /$ week, and about $52 \%$ when restricted to $40 \mathrm{hr} /$ week. As a consequence, regulation-induced income and employment effects would be severe in these establishments. Other major establishment categories in which such effects are also likely to be significant include general merchandise and food.

Appendix $E$ presents a detailed computation of the direct income effect that occurs in the commercial sector as a result of a reduction in operating hours. The income effect stems from the translation of reduced hours of work into an income loss; the results are shown in Table 4.9. The average quarterly income loss at annual rates is $\$ 4.5$ billion wheir commercial establishments are restricted to $60 \mathrm{hr} /$ week, and $\$ 13$ billion when establishments are restricted to $40 \mathrm{hr} /$ week.

In addition to a direct loss of income to employees of these establishments, there is a secondary loss of income to the economy, as lost purchasing power of displaced workers reduces effective demand throughout the economy.

There are also secondary employment effects as released workers from the commercial sector reduce consumer demand and retard economic growth, leading to further job losses. Direct employment effects of the regulation are not easily determined because available data do not reveal the number of part-time and full-time employees that firms would choose to layoff as a direct result of the regulation. However, it is possible to estimate an overall unemployment equivalent associated with the resultant loss in income (primary and secondary). These results are presented in Appendix E. 
Tabie 4.8. National average man-hours, wage rates, and employment in business establishments likely to be affected by regulation ${ }^{\alpha}$

\begin{tabular}{|c|c|c|c|c|c|c|c|c|c|}
\hline \multirow{2}{*}{$\begin{array}{l}\text { Categories of } \\
\text { business } \\
\text { establishments }\end{array}$} & \multirow{2}{*}{$\begin{array}{c}\text { Normal average } \\
\text { annual hours } \\
\text { worked / employee } \\
\text { (nonsupervisory } \\
\text { employees) }\end{array}$} & \multicolumn{4}{|c|}{$\begin{array}{l}\text { Wage rate }(\$ / \text { hr in } \\
\text { current dollars) }\end{array}$} & \multicolumn{4}{|c|}{ Employment in thousands } \\
\hline & & $1980: 4$ & 1981:1 & $1981: 2$ & $1981: 3$ & $1980: 4$ & $1981: 1$ & $1981: 2$ & $1981: 3$ \\
\hline $\begin{array}{l}\text { Building materials, } \\
\text { hardware, etc. }\end{array}$ & 1995 & 5.68 & 5.78 & 5.88 & 5.99 & 626.9 & 634.5 & 639.1 & 643.2 \\
\hline General merchandise & 1530 & 4.88 & 4.97 & 5.06 & 5.15 & 2575.7 & 2594.4 & 2612.9 & 2629.9 \\
\hline Food & 1620 & 6.09 & 6.20 & 6.31 & 6.42 & 2183.7 & 2199.6 & 2215.3 & 2229.7 \\
\hline Automotive dealərs & 1975 & 6.35 & 6.47 & 6.59 & 6.70 & 1077.8 & 1085.7 & 1093.4 & 1100.5 \\
\hline $\begin{array}{l}\text { Gasoline service } \\
\text { stations }\end{array}$ & $1 \ni 50$ & 4.46 & 4.54 & 4.62 & 4.70 & 587.9 & 592.2 & 596.5 & 600.3 \\
\hline $\begin{array}{l}\text { Apparel \& } \\
\text { accessories }\end{array}$ & 1485 & 4.45 & 4.53 & 4.61 & 4.69 & 783.9 & 789.6 & 795.3 & 800.4 \\
\hline Furniture & 1785 & 5.71 & 5.82 & 5.92 & 6.03 & 518.0 & 521.8 & 525.4 & 528.8 \\
\hline Eating \& drinking & 1365 & 3.75 & 3.82 & 3.89 & 3.96 & 4129.5 & 4159.6 & 4189.2 & 4216.4 \\
\hline Drug stores & 1560 & 4.61 & 4.70 & 4.78 & 4.86 & 475.9 & 479.3 & 482.8 & 485.9 \\
\hline Other retail & 1815 & 5.46 & 5.56 & 5.66 & 5.76 & 1035.8 & 1043.4 & 1050.8 & 1057.7 \\
\hline Personal services & $1 ; 10$ & 4.70 & 4.79 & 4.87 & 4.96 & 383.0 & 386.0 & 339.0 & 392.0 \\
\hline Other services & 1800 & 6.41 & 6.53 & 6.64 & 6.76 & 1303.0 & 1313.0 & 1323.0 & 1334.0 \\
\hline
\end{tabular}

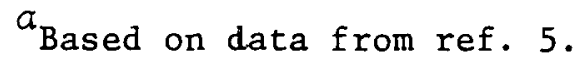


Table 4.9. Fegulation-induced income loss in the commercial sector (quarterly at annual rates)

\begin{tabular}{|c|c|c|c|c|c|c|c|c|}
\hline \multirow{3}{*}{$\begin{array}{l}\text { Catagories of } \\
\text { business } \\
\text { establishments }\end{array}$} & \multicolumn{8}{|c|}{$\begin{array}{c}\text { Reduction in wages with reduction in hours worked } \\
\text { (billions of current } \$ \text { ) }\end{array}$} \\
\hline & \multicolumn{4}{|c|}{ 60-br week } & \multicolumn{4}{|c|}{ 40-hr week } \\
\hline & $1980: 4$ & $1981: 1$ & 1981:2 & $1981: 3$ & $1980: 4$ & $1981: 1$ & $1981: 2$ & $1981: 3$ \\
\hline $\begin{array}{l}\text { Building materials, } \\
\text { hardware, etc. }\end{array}$ & & & & & 0.298 & 0.305 & 0.313 & 0.321 \\
\hline General merchandise & 0.803 & 0.824 & G. 845 & 0.865 & 2.135 & 2.189 & 2.246 & 2.300 \\
\hline Food & 0.899 & 0.922 & 0.945 & $0.96 \varepsilon$ & 2.392 & 2.453 & 2.513 & 2.574 \\
\hline Automotive dealers & & & & & 0.876 & 0.899 & 0.921 & 0.943 \\
\hline $\begin{array}{l}\text { Gasoline service } \\
\text { stations }\end{array}$ & 0.548 & 0.562 & $(1.576$ & 0.591 & 0.791 & 0.811 & 0.832 & 0.852 \\
\hline $\begin{array}{l}\text { Apparel \& } \\
\text { accessories }\end{array}$ & 0.217 & $0.2 \approx 2$ & 0.227 & $0.23 z$ & 0.575 & 0.590 & 0.605 & 0.619 \\
\hline Furniture & & & & & 0.439 & 0.451 & 0.462 & 0.473 \\
\hline Eating \& drinking & 1.511 & 1.551 & -.590 & 1.630 & 2.769 & 2.842 & 2.914 & 2.986 \\
\hline Drug stcres & 0.245 & 0.252 & 0.257 & 0.263 & 0.448 & 0.460 & 0.472 & 0.482 \\
\hline Other $r \in t a i l$ & & & & & 0.665 & 0.683 & 0.700 & 0.716 \\
\hline Personal services & 0.129 & 0.132 & 0.135 & 0.139 & 0.342 & 0.351 & 0.360 & 0.369 \\
\hline Other services & & & & & 0.973 & 0.999 & 1.024 & 1.051 \\
\hline Total & 4.352 & 4.465 & 4.575 & 4.688 & 12.703 & 13.033 & 13.362 & 13.686 \\
\hline
\end{tabular}


4.3.2.3 Sales effect. In addition to the income and employment effect, there may be a sales effect that is a possible outcome of the regulation. The decline in sales was considered to occur only in the selected categories shown in Appendix E. Primarily, these declines affect department stores, other retail, eating and drinking establishments, and recreational-type services. Purchases of durable goods such as automobiles, furniture, and building materials are representative of long-term decisions for the consumers and producers. Consequently, buying patterns will adjust to the stores operating hours without affecting sales. Gasoline sales are likely to decline marginally and only in the pleasure-driving category, which is small. In the short run, individuals may find it difficult to alter commuting patterns, shopping habits, or other similar-type trips. Moreover, mass transit may not be capable of accommodating these changes unless the focus is on individuals living in large cities with well-developed transit systems.

The detailed computation of the decline in sales that could result from reduced operating hours is presented in Appendix E; the results are shown in Table 4.10. The average quarterly sales decline at annual rates Is $\$ 13.8$ billion when establishments are restricted to $60 \mathrm{hr} /$ week, and $\$ 41.3$ billion under the more severe $40-\mathrm{hr} /$ week restriction.

\subsubsection{Energy effect. Energy savings in the commerclal sector}

that result from restricting operating hours are made available to the manufacturing sector, so that the energy shortfall in that sector ( 0.6 million bbl/day) is effectively reduced. Table 4.11 shows the regulation-induced reduction in energy demand in the commercial sector to be 0.15 and 0.175 million bbl/day for the $60-$ and 40 -hr cases respectively. As a consequence, the energy shortfall to the manufacturing sector correspondingly declines to 0.45 and 0.425 million bbl/day respectlvely.

Increasing the amount of energy available to the manufacturing sector has a positive effect on industrial activity in that sector which contributes to economic growth. However, Sect. 4.3.3 indicates that this additional energy is not sufficient to offset the dampening effects on economic activity that result from losses in income and sales in the commercial sector. 
Table 4.10. Regulation-induced reduction in commercial sector sales (billions of current $\$$ at annual rates)

\begin{tabular}{ccccc}
\hline & \multicolumn{4}{c}{ Time period } \\
\cline { 2 - 5 } Cases & $1980: 4$ & $1981: 1$ & $1981: 2$ & $1981: 3$ \\
\hline 60-hr week & 12.8 & 14.1 & 14.1 & 14.1 \\
40-hr week & 38.3 & 42.3 & 42.3 & 42.3 \\
\hline
\end{tabular}

Table 4.1l. Energy effect of regulation (million bbl/day)

\begin{tabular}{|c|c|c|c|c|}
\hline & \multicolumn{4}{|c|}{ Time period } \\
\hline & $1980: 4$ & 1981:1 & $1981: 2$ & $1981: 3$ \\
\hline $\begin{array}{l}\text { Energy shortfall to } \\
\text { manufacturing } \\
\text { sector in baseline } \\
\text { economy. }\end{array}$ & -0.6 & -0.6 & -0.6 & -0.6 \\
\hline \multicolumn{5}{|l|}{$\begin{array}{l}\text { Regulation-induced } \\
\text { increase in energy } \\
\text { availability }\end{array}$} \\
\hline $\begin{array}{l}\text { 60-hr week } \\
40-\mathrm{hr} \text { week }\end{array}$ & $\begin{array}{l}+0.15 \\
+0.175\end{array}$ & $\begin{array}{l}+0.15 \\
+0.175\end{array}$ & $\begin{array}{l}+0.15 \\
+0.175\end{array}$ & $\begin{array}{l}+0.15 \\
+0.175\end{array}$ \\
\hline \multicolumn{5}{|l|}{$\begin{array}{l}\text { Encrgy ohortfall } \\
\text { to manufacturing } \\
\text { sector under } \\
\text { regulation }\end{array}$} \\
\hline $\begin{array}{l}\text { 60-hr week } \\
\text { 40-hr week }\end{array}$ & $\begin{array}{l}-0.450 \\
-0.425\end{array}$ & $\begin{array}{l}-0.450 \\
-0.425\end{array}$ & $\begin{array}{l}-0.450 \\
-0.425\end{array}$ & $\begin{array}{l}-0.450 \\
-0.425\end{array}$ \\
\hline $\begin{array}{l}\text { Index of industrial } \\
\text { production- } \\
\text { manufacturing } \\
\text { baseline economy }\end{array}$ & 1.449 & 1.478 & 1.496 & 1.505 \\
\hline \multicolumn{5}{|l|}{$\begin{array}{l}\text { Economy under } \\
\text { regulation }\end{array}$} \\
\hline $\begin{array}{l}\text { 60-hr week } \\
40-\mathrm{hr} \text { week }\end{array}$ & $\begin{array}{l}1.478 \\
1.483\end{array}$ & $\begin{array}{l}1.506 \\
1.511\end{array}$ & $\begin{array}{l}1.524 \\
1.529\end{array}$ & 1.534 \\
\hline
\end{tabular}




\subsubsection{Detailed economic analysis of the regulation}

The methodology used in this study assumes the energy "saved" by the conservation regulation is "spent" in the manufacturing sector to offset the economic impacts of the energy shortfall. Because earlier results indicate the negative impacts of the regulation, it is important to investigate the reasons that the manufacturing sector fails to offset these effects.

There are two explanations for this situation. First, the energy saved by the regulations is quite small and fails to stimulate industrial activity significantly. Furthermore, the supply response in the industrial sector may be quite small and cannot produce large effects in the short run. In viewing reemployment possibilities, workers' skills in the commercial and industrial sectors differ greatly. Consequently, without retraining, which is a lengthly process, the worker reabsorption rate is low.

The second explanation relies on the income loss induced by the regulation's effect on man-hours worked. As previously mentioned, the small energy savings spent in the manufacturing sector, plus the low reabsorption rate, does not fully offset this manpower-income reduction. This income loss, however, has multiplier impacts which influence economic activity in a more substantial manner. The common theme found in all scenarios call be described as follows:

- Reduce man-hours result in a decline in income.

- Aggregate demand falls as income declines and affects consumption patterns.

- Inventory buildup and the subsequent falloff in fixed investment follow the decline in aggregate demand.

- Real GNP declines relative to the baseline.

- Consumer prices soften due to reduced demand pressures.

- The unemployment rate equivalent determined from income loss increases relative to the baseline.

The economic forces that amplify the initial income loss are augmented by assuming a decline in sales, particularly in the 40-hr case. Even 
without this assumption, however, the negative impacts are still significant. Figures 4.3 to 4.11 display these results over the relevant time period. Tables E-7 and E-10 (Appendix E) provide the data for all the cases described.

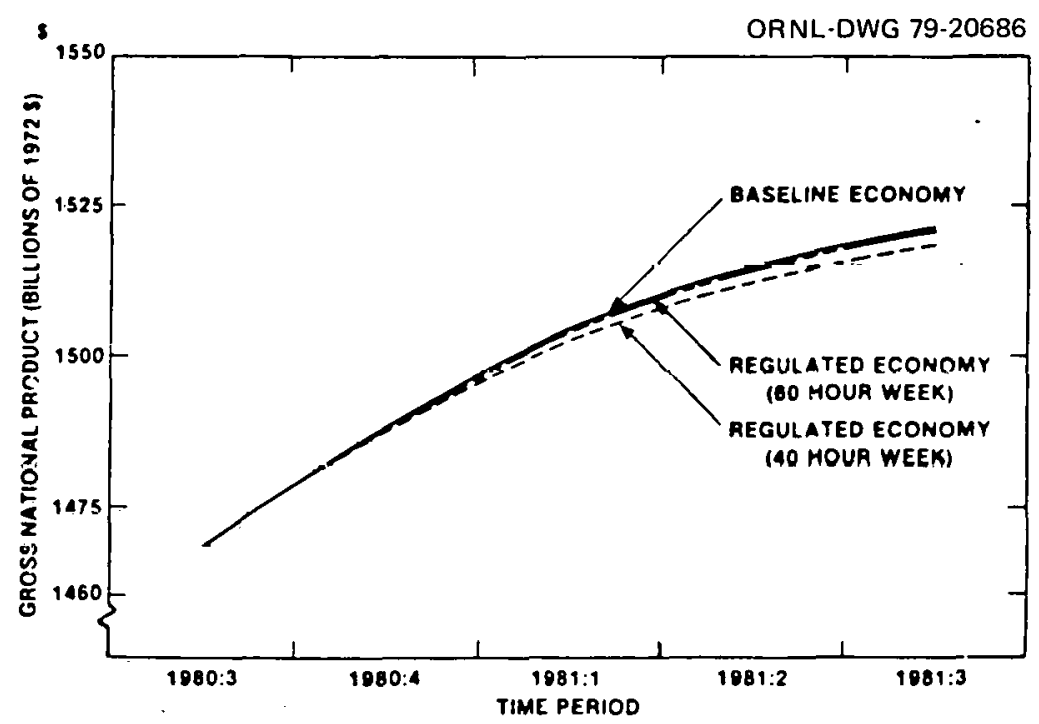

Fig. 4.3. Impact of regulation on real. GNP without commercial sector sales decline.

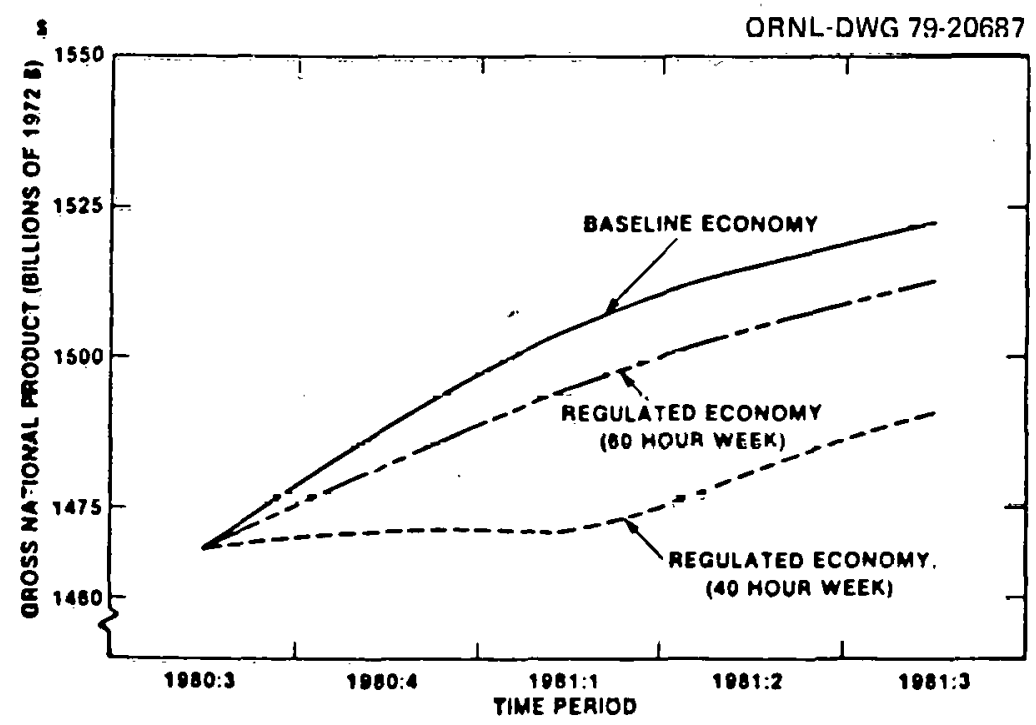

Fig. 4.4. Impact of regulation on real GNP with commercial sector sales decline. 


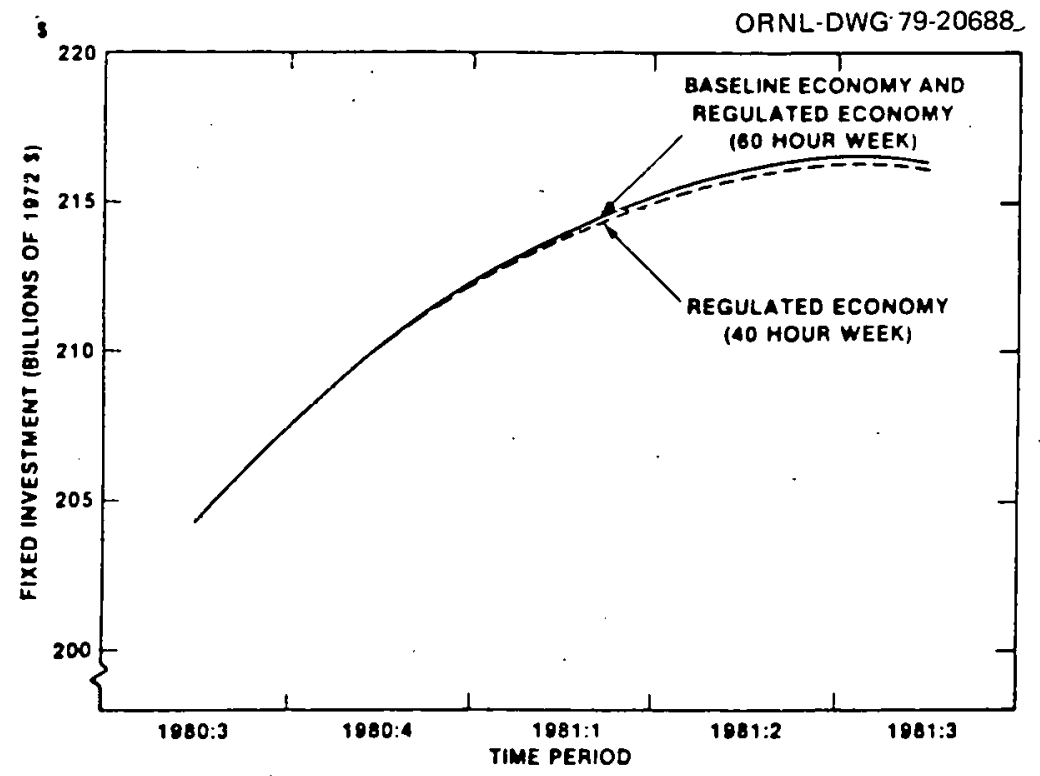

Fig. 4.5. Impact of regulation on real gross private domestic fixed investment without commercial sector sales decline.

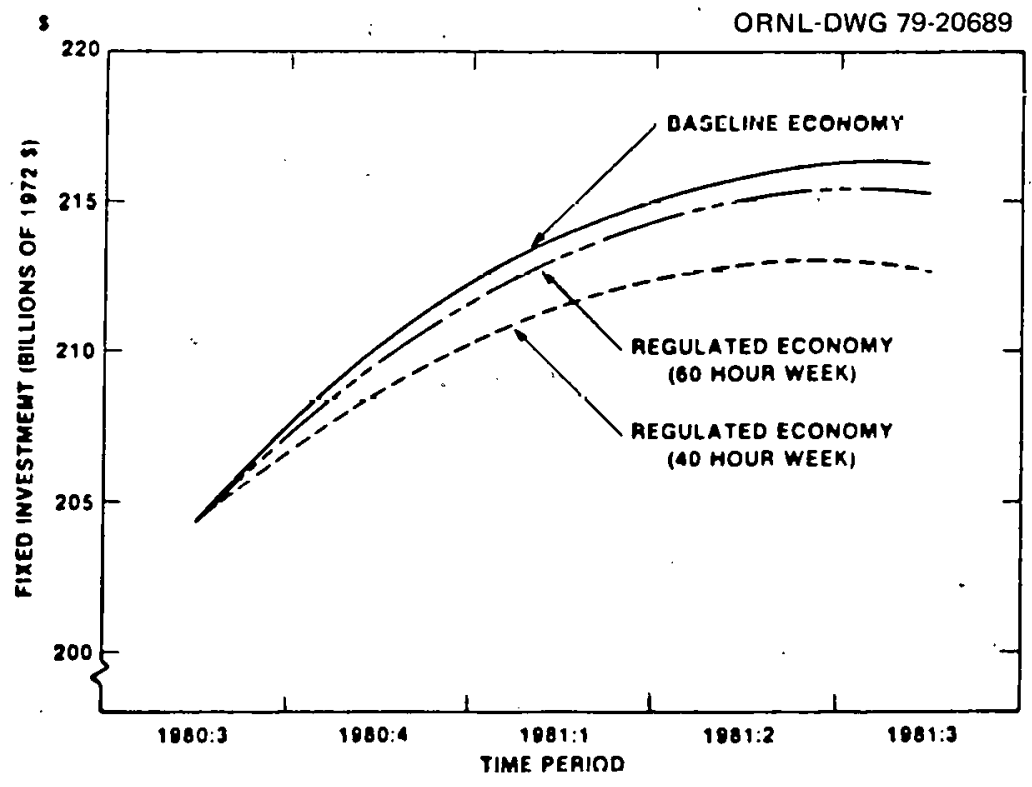

Fig. 4.6. Impact of regulation on real gross private domestic fixed investment with commercial sector sales decline. 


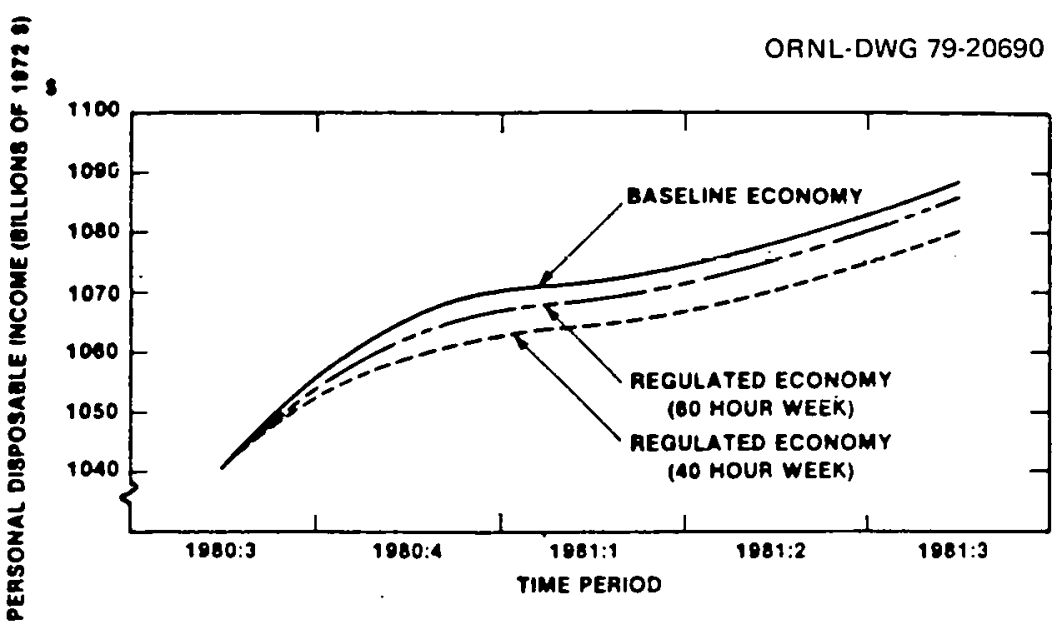

Fig. 4.7. Impact of regulation on real personal disposable income without commercial sector sales decline.

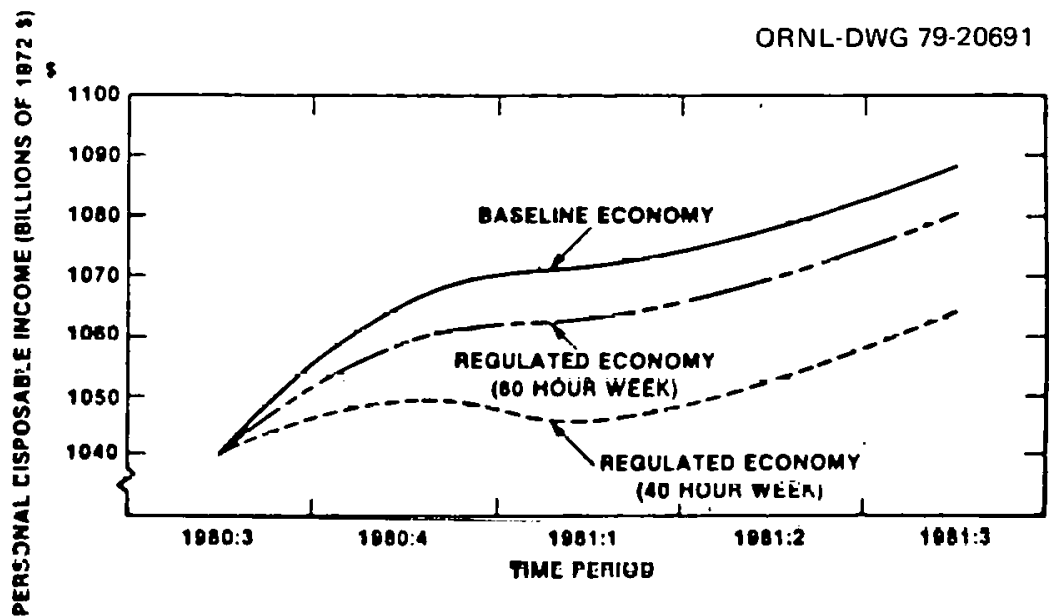

Fig. 4.8. Impact of regulation on real personal disposable income with commercial sector sales decline.

\subsubsection{Regional economic impacts}

Lconomic Impuls were analyzed for DOE regiono I, IV, and VI for the period 1980:4 to 1981:3, focusing on regulation-induced impacts on regional employment and income relative to the baseline case.

The major assumptions underlying the analysis were as follows:

- Regulations would be implemented uniformly across the regions, and responses of firms and consumers in each region would be similar. 
ORNL-DWG 79-20692

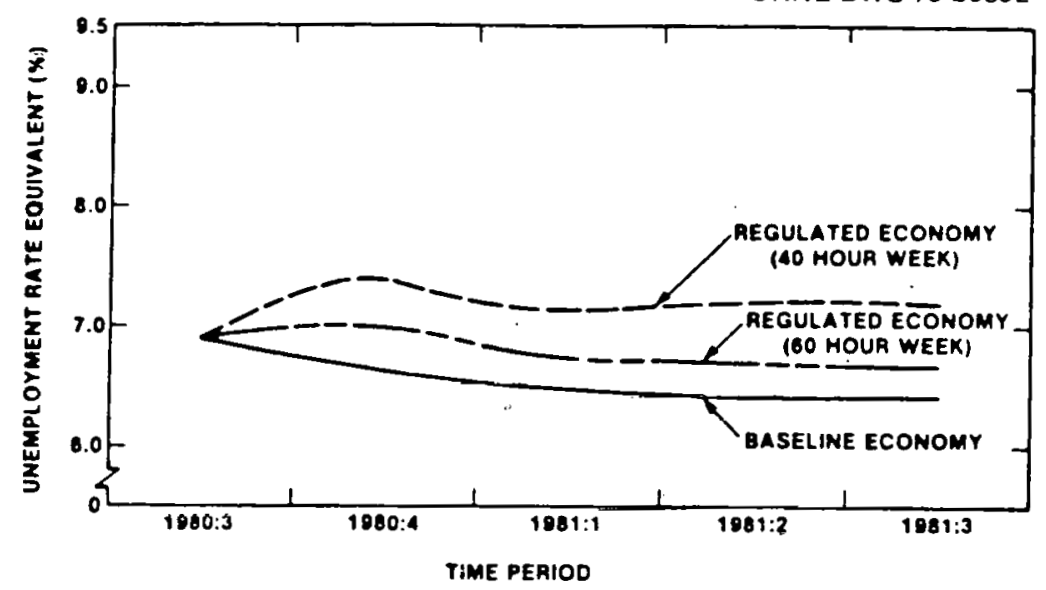

Fig. 4.9. Unemployment rate equivalent of income loss without commercial sector sales decline.

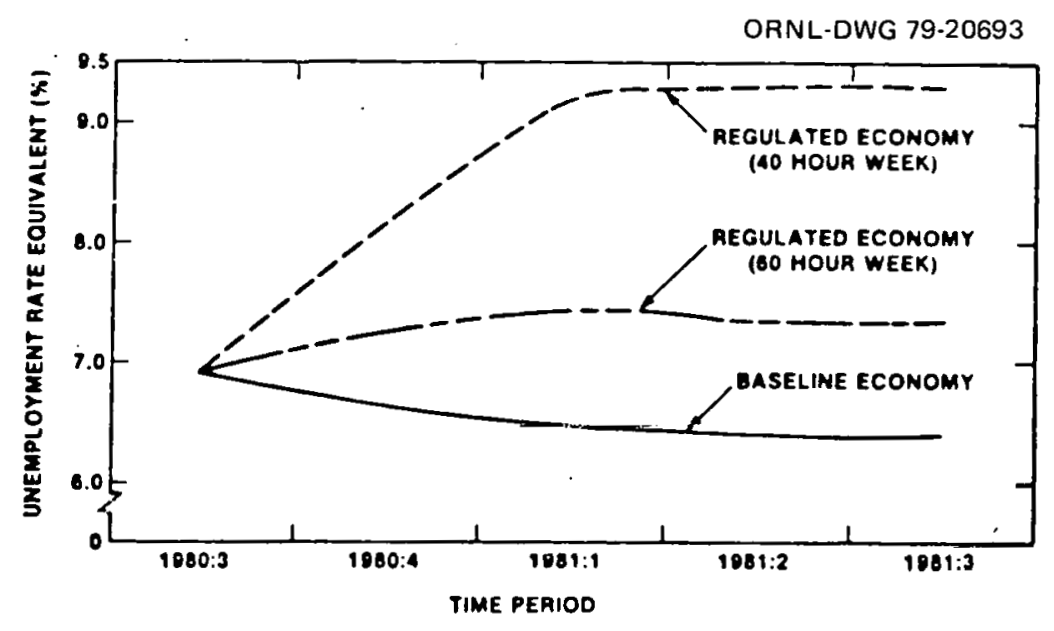

Fig. 4.10. Unemployment rate equivalent of Income loss with commercial sector sales decline.

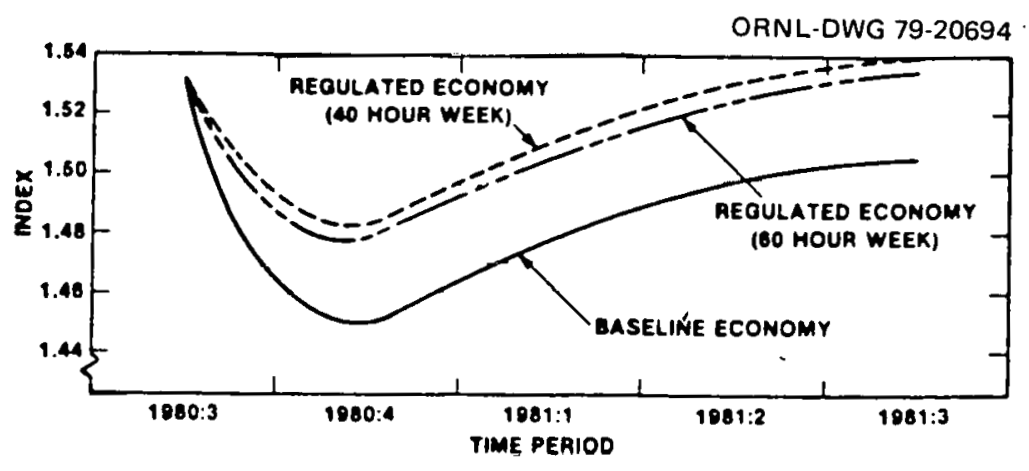

Fig. 4.11. Index of industrial production manufacturing in the baseline and regulated economies. 
- Regional impacts within the commercial sector will be proportional to the extent of the sector's activity measured by its share of sales, employment, and wages relative to national levels.

- Multiplier effects of sector-specific income and employment losses determined nationally are applicable regionally.

The analytic approach and supporting data are given in Appendix E; the results are presented and discussed here.

Regional shares of key economic and demographic variables in the 1980-81 time period are shown in Table 4.12 for the baseline case. Of the three regions considered, region $I$ is expected to show a slight decline in its projected shares of population, labor force, employment, and income, while regions IV and VI are expected to show a modest increase.

The regional patterns of commercial sector activity (in retail trade and selected service categories) relative to national aggregate levels are shown in Table 4.13 for the 1980-81 period (see Appendix F). These patterns follow overall economic activity in the regions. It is apparent that region IV with the most extensive commerclal activity will experience the greatest losses in income, employment, and sales from the implementation of the regulation.

Reductions in commercial sector wages and sales at the regional level were determined using the data in Table 4.13 (see Appendix E). These sector-specific regional impacts are shown in Table 4.14 for both the 60- and 40-hr cases.

As described previously, direct employment effects of regulation are not easily determined. However, an overall regional unemployment equivalent of income loss (both primary losses within the commercial sector and induced secondary losses elsewhere in the economy) has been computed and is presented in Table 4.15.

Below the regional level, examination of the economic profile of individual states suggests that regional aggregation masks important variations evident at the state level. Some states are growing rapidly and are likely to have greater capacity to absorb shocks than others. However, on balance, differences in economic characteristics of individual states tend to be neutralized at the regional level. Consequently, to a 
Tabie 4.12. Key economic and demographic variables in $1980-81$ relative to nationala (baseline case)

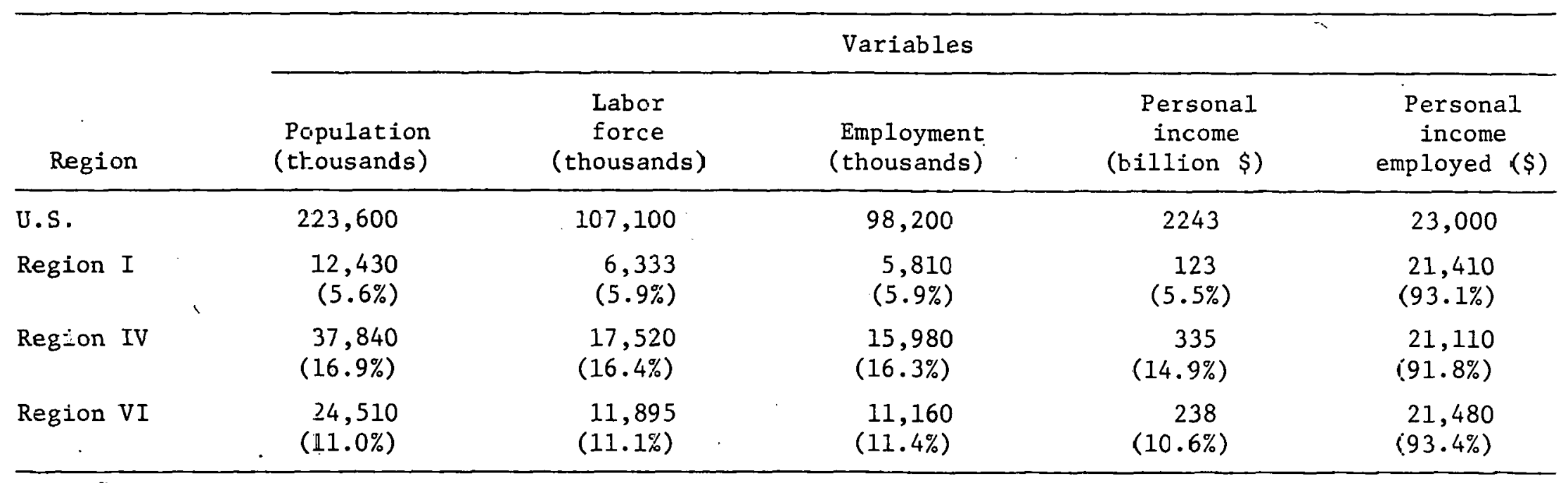

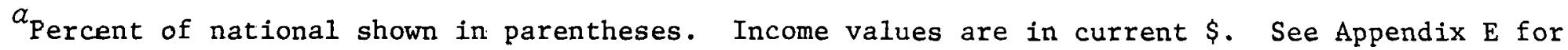
details. 
Table 4.13. Regional shares of commercial sector activity in retaj,1 trade and selected services relative to national $a$

(baseline case 1980-81)

\begin{tabular}{|c|c|c|c|c|}
\hline \multirow[b]{2}{*}{ Region } & \multicolumn{3}{|c|}{ Variables } & \\
\hline & $\begin{array}{l}\text { Employment } \\
\text { (thousands) }\end{array}$ & \multicolumn{2}{|c|}{$\begin{array}{c}\text { Wages } \\
\text { (billion } \$ \text { ) }\end{array}$} & $\begin{array}{l}\text { Sales } \\
\text { (billion } \$)\end{array}$ \\
\hline U.S. & 18,000 & \multicolumn{2}{|c|}{214} & 1240 \\
\hline Region I & $\begin{array}{c}1,062 \\
(5.9 \%)\end{array}$ & \multicolumn{2}{|c|}{$\begin{array}{l}11.77 \\
(5.5 \%)\end{array}$} & $\begin{array}{c}63 \\
(5.1 \%)\end{array}$ \\
\hline Region IV & $\begin{array}{r}2,754 \\
(15.3 \%)\end{array}$ & \multicolumn{2}{|c|}{$\begin{array}{c}31.89 \\
(14.9 \%)\end{array}$} & $\begin{array}{c}197 \\
(15.9 \%)\end{array}$ \\
\hline Region VI & $\begin{array}{r}2,052 \\
(11.4 \%)\end{array}$ & \multicolumn{2}{|c|}{$\begin{array}{c}22.68 \\
(10.6 \%)\end{array}$} & $\begin{array}{c}140 \\
(11.3 \%)\end{array}$ \\
\hline \multicolumn{5}{|c|}{$\begin{array}{l}\text { a Percent of national shown in parentheses. Wage and } \\
\text { sales values are in current } \$ \text {. See Appendix E for detail } \\
\text { Table 4.14. Regulation-induced reduction in wages and } \\
\text { sales in the commercial sector } 1980: 4 \text { through } \\
1981: 3 \text { (billions of current } \$ \text { ) }\end{array}$} \\
\hline \multirow[b]{3}{*}{ Region } & \multicolumn{4}{|c|}{ Impacts } \\
\hline & \multicolumn{2}{|c|}{ 60-hr week } & \multicolumn{2}{|c|}{ 40-hr week } \\
\hline & $\begin{array}{c}\text { Wage } \\
\text { reduction }\end{array}$ & $\begin{array}{l}\text { Sales } \\
\text { reduction }\end{array}$ & $\begin{array}{c}\text { Wage } \\
\text { reduction }\end{array}$ & $\begin{array}{l}\text { Sales } \\
\text { reduction }\end{array}$ \\
\hline U.S. & 4.52 & 13.78 & 13.20 & 41.30 \\
\hline Region I & 0.25 & 0.70 & 0.73 & 2.11 \\
\hline Region IV & 0.67 & 2.19 & 1.97 & 6.57 \\
\hline Region VI & 0.48 & 1.56 & 1.40 & 4.67 \\
\hline
\end{tabular}

first (and probably reasonable) approximation, secondary effects on income and employment at the regional level (induced by primary impacts on the commercial sector) would be very similar when measured in relation to each region's baseline economy. Thus, while impacts within the commercial sector are influenced by the sector-specific economic activity 
Table 4.15. Regulation-induced losses in regional disposable income ${ }^{a}$ - 1980:4 through 1981:3

(billions of current \$)

\begin{tabular}{|c|c|c|c|c|c|}
\hline \multirow[b]{4}{*}{ Region } & \multirow{4}{*}{$\begin{array}{c}\text { Disposable } \\
\text { income } \\
\text { (baseline) }\end{array}$} & \multicolumn{4}{|c|}{ Impacts } \\
\hline & & \multicolumn{4}{|c|}{ Loss in disposable income } \\
\hline & & \multicolumn{2}{|c|}{ 60-hr week } & \multicolumn{2}{|c|}{ 40-hr week } \\
\hline & & $\begin{array}{c}\text { Without } \\
\text { sales loss }\end{array}$ & $\begin{array}{c}\text { With sales } \\
\text { loss }\end{array}$ & $\begin{array}{c}\text { Without } \\
\text { sales loss }\end{array}$ & $\begin{array}{c}\text { With sales } \\
\text { loss }\end{array}$ \\
\hline U.S. & 1972.3 & 5.87 & 14.66 & 14.48 & 42.16 \\
\hline Region I & 108.5 & 0.32 & 0.81 & 0.80 & 2.32 \\
\hline Region IV & 293.8 & 0.88 & 2.19 & 2.16 & 6.29 \\
\hline Region VI & 209.0 & 0.62 & 1.56 & 1.54 & 4.48 \\
\hline
\end{tabular}

in each region, impacts across all sectors are determined by each region's overall economic makeup.

Primary and secondary losses in regional disposable income and the unemployment equivalent of the income loss are presented in Tables 4.1.5 and 4.16 (see Appendix E). They represent impacts for the 60- and 40-hrweek restrictions on commercial sector operating hours, both with and without the addition of the loss in sales in the sector.

A comparison of the regional impacts on income and employment indicates that region IV would suffer the greatest losses on an absolute basis and region I the least. On a relative basis (i.e., with respect to each region's baseline economy) the incremental impacts are seen to be similar to those computed nationally.

The unemployed workers may have difficulty in finding employment outside the commercial sector. At a local level it is not unlikely that these unemployed workers would be forced to relocate, or become a part of the permanently unemployed. This condition places additional burdens on the local and state governments as transfer payments increase. The potentlal for a subsequent rise in taxes will further worsen the situation 
Table 4.16. Regulation-induced increases in regional unenployment and resultant 'unemploynent rates $^{\alpha}-1980: 4$ through 19:1:3

\begin{tabular}{|c|c|c|c|c|c|c|}
\hline \multirow[b]{4}{*}{ Region } & \multirow{4}{*}{. } & \multirow{4}{*}{$\begin{array}{c}\text { Baseline } \\
\text { unemployment } \\
\text { level and } \\
\text { rate }\end{array}$} & \multicolumn{4}{|c|}{ Injacts } \\
\hline & & & \multicolumn{4}{|c|}{$\begin{array}{c}\text { Increase in unemployment and unemployment } \\
\text { rate uncier regulation }\end{array}$} \\
\hline & & & \multicolumn{2}{|c|}{ 60-hr week } & \multicolumn{2}{|c|}{ 40-hr week } \\
\hline & & & $\begin{array}{l}\text { Without } \\
\text { sales loss }\end{array}$ & $\begin{array}{l}\text { With sales } \\
\text { loss }\end{array}$ & $\begin{array}{l}\text { Without } \\
\text { sales loss }\end{array}$ & $\begin{array}{c}\text { With sales } \\
\text { loss }\end{array}$ \\
\hline $\mathrm{U} . \mathrm{S}$. & & $\begin{array}{l}7,000,000 \\
(6.50 \%)\end{array}$ & $\begin{array}{l}299,500 \\
(6.78 \%)\end{array}$ & $\begin{array}{l}741,000 \\
(7.19 \%)\end{array}$ & $\begin{array}{l}734,000 \\
(7.18 \%)\end{array}$ & $\begin{array}{l}2,133,000 \\
(8.49 \%)\end{array}$ \\
\hline Region I & 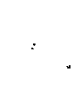 & $\begin{array}{l}414,000 \\
(6.55 \%)\end{array}$ & $\begin{array}{r}17,580 \\
(6.82 \%)\end{array}$ & $\begin{array}{r}43,900 \\
(7.24 \%)\end{array}$ & $\begin{array}{r}43,400 \\
(7.23 \%)\end{array}$ & $\begin{array}{l}126,300 \\
(8.54 \%)\end{array}$ \\
\hline Region IV & & $\begin{array}{c}1,235,000 \\
(7.06 \%)\end{array}$ & $\begin{array}{r}43,400 \\
(7.33 \%)\end{array}$ & $\begin{array}{l}120,900 \\
(7.75 \%)\end{array}$ & $\begin{array}{l}119,500 \\
(7.74 \%)\end{array}$ & $\begin{array}{l}347,700 \\
(9.04 \%)\end{array}$ \\
\hline Region VI & & $\begin{array}{l}528,000 \\
(4.44 \%)\end{array}$ & $\begin{array}{r}33,800 \\
(4.73 \%)\end{array}$ & $\begin{array}{r}84,500 \\
(5.15 \%)\end{array}$ & $\begin{array}{r}83,500 \\
(5.14 \%)\end{array}$ & $\begin{array}{l}243,000 \\
(6.49 \%)\end{array}$ \\
\hline
\end{tabular}

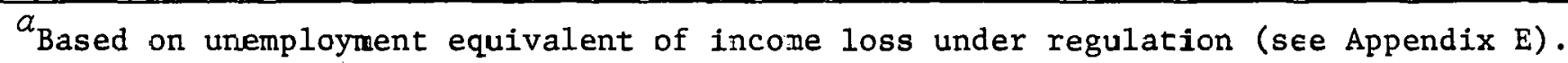


as consumer's disposable income is reduced. However, the temporary nature of the regulation may allow these conditions to be reversed when the regulation expires, but the reversal may not necessarily be complete.

\subsection{Environmental Impacts}

\subsubsection{Overview of results}

The impacts on the physical environment of regulation restricting the hours of operation of commercial establishments are minor, both at the national and regional levels. The criteria pollutants considered were: particulates, sulfur oxides $\left(\mathrm{SO}_{\mathrm{x}}\right)$, nitrogen oxides ( $\mathrm{NO}_{x}$ ), hydrocarbons $(\mathrm{HC})$, and carbon monoxide $(\mathrm{CO})$. The environmental impacts were measured as changes in the level of pollutants relative to a baseline environment described in Appendix F. The impacts were estimated from a change in the pattern of fuel use under regulation, wherein petroleum and natural gas savings in the commercial and utility sectors were assumed to be used in the manufacturing sector. These impacts at the national level are shown in Table 4.17 .

Environmental impacts of regulation at the regional level were similarly estimated for DOE regions I, IV, and VI for just the 60-hr cise. In all three regions the environmental impacts are also small (see Table 4.18).

The results shown in Tables 4.17 and 4.18 are presented as calculated, and no implications to accuracy are intended. In fact the exceedingly small changes in emission levels (both nationally and in the selected regions) are probably well within the margins of error associated with data from the Strategic Environmental Assessment System (SEAS) model used in this study. Additionally, since savings in the utility use of coal were not assumed to be used elsewhere, it is reasonable to expect an overall reduction in emissions for all of the criteria pollutants considered.

The human factors aspect addressing social implications of the regulation (such as economic equity, increased need for social services because of unemployment, etc.) is briefly described. While a detailed analysis 
Table 4.17. Emission changes at the national level from regulation restricting commercial sector operating hours

\begin{tabular}{lcr}
\hline & \multicolumn{2}{c}{$\begin{array}{c}\text { Percent of change relative } \\
\text { to national emissions }\end{array}$} \\
\cline { 2 - 3 } Pollutant & $60-\mathrm{hr}$ case & $40-\mathrm{hr}$ case \\
\hline Particulates & $<0.01$ & $<0.01$ \\
SO & $<0.01$ & $<0.01$ \\
NO $_{\mathrm{x}}$ & 0.03 & 0.03 \\
Hydrocarbons & $<0.01$ & $<0.01$ \\
Carbon monoxide & $<0.01$ & $<0.01$ \\
\hline
\end{tabular}

Baseline national average emission levels in 1980-81 (Appendix F):

Pollutants Quantity of pollutant ( $10^{3}$ tons)

$\begin{array}{ll}\text { Particulates } & 11,866 \\ \mathrm{SO}_{\mathrm{x}} & 26,756 \\ \mathrm{NO}_{\mathrm{x}} & 17,241 \\ \text { Hydrocarbons } & 11,691 \\ \text { Carbon monoxide } & 54,500\end{array}$

Table 4.18. Emission changes at the regional level from regulation restricting commercial sector operating hours: $60-\mathrm{hr}$ case

Pollutants

Fercent clange in emission levelo relativo

to respective baseline emissions $a$

\begin{tabular}{lccccc} 
& Particulates & $\begin{array}{c}\text { Sulfur } \\
\text { oxides }\end{array}$ & $\begin{array}{c}\text { Nitrngen } \\
\text { oxides }\end{array}$ & $\begin{array}{c}\text { Hydro- } \\
\text { carbons }\end{array}$ & $\begin{array}{c}\text { Carbon } \\
\text { monoxide }\end{array}$ \\
\hline Region I & -0.30 & -0.98 & +0.38 & -0.02 & $-<0.01$ \\
Region IV & +0.07 & +0.15 & +0.58 & +0.01 & +0.01 \\
Region VI & +0.01 & +0.12 & $+<0.01$ & $-<0.01$ & $-<0.01$ \\
\hline
\end{tabular}

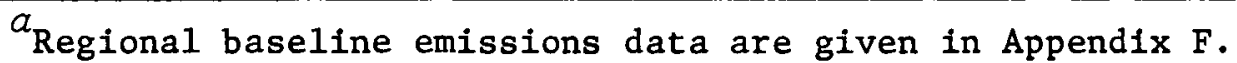


of these factors was outside the scope of this study, they are nevertheless identified because they are important components of the regulatory decision-making process.

\subsubsection{Energy impacts}

The principal effect of restricted hours would be a direct reduction in energy demand in commercial establishments (petroleum fuels, natural gas, and electricity) and an indirect reduction in the use of utility fuels. The direct and indirect savings in petroleum and natural gas computed nationally (see Sect. 4.2) were assumed to be used in the manufacturing sector, as shown in Table 4.19. Distribution of these fuel savings to the manufacturing sectors in each region was assumed to be in proportion to the baseline regional shares of petroleum fuel consumption in the sectors (see Appendix F). On this basis the quantities shifted to the sector are shown in Table 4.20. Savings in the utility use of coal were not assumed to be used elsewhere.

It is interesting to note that region IV with the lowest level of fuel savings under the regulation has a substantially greater amount of fuel allocated to its manufacturing sector (over twice as much). Region VI

Table 4.19. Regulation-induced shifts of petroleum fuels and natural gas at the national level from the commercial and utilities sectors to the manufacturing sector $a$ $\left(10^{12} \mathrm{Btu}\right)$

\begin{tabular}{|c|c|c|c|c|}
\hline Fuel & From & $\begin{array}{l}\text { commercial } \\
\text { sector }\end{array}$ & $\begin{array}{c}\text { From utilities } \\
\text { sector }\end{array}$ & $\begin{array}{c}\text { To manufacturing } \\
\text { sector }\end{array}$ \\
\hline \multicolumn{5}{|c|}{ 60-hr case } \\
\hline Petròleum fuels & & 102 & 48 & 150 \\
\hline Natural gas & & 148 & 42 & 190 \\
\hline \multicolumn{5}{|c|}{ 40-hr case } \\
\hline Petroleum fuels & & 121 & 57 & 178 \\
\hline Natural gas & & 175 & 50 & 225 \\
\hline
\end{tabular}

$a_{\text {See Sect. }}$ 4.2. 
Table 4.20. Regulation-induced shifts of petroleum and national gas at the regional level from commercial and utilities sectors to the manufacturing sector: $60-\mathrm{hr}$ case $\left(10^{12} \mathrm{Btu}\right)$

\begin{tabular}{llrrr}
\hline & \multicolumn{1}{c}{ Fuel } & $\begin{array}{c}\text { From } \\
\text { commercial } \\
\text { sector }\end{array}$ & $\begin{array}{c}\text { From } \\
\text { utilities } \\
\text { sector }\end{array}$ & $\begin{array}{c}\text { To } \\
\text { manufacturing } \\
\text { sector }\end{array}$ \\
\hline Region I & Petroleum & 22.83 & 8.62 & 15.60 \\
& Natural gas & 3.30 & 0.03 & 19.76 \\
Region IV & Petroleum & 6.57 & 9.96 & 35.70 \\
& Natural gas & 10.65 & 3.60 & 45.22 \\
Region VI & Petroleum & 3.23 & 0.85 & 9.45 \\
& PNatulal gás & 20.14 & 24.23 & 11.97 \\
\hline
\end{tabular}

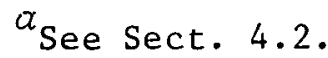

bee Appendix F.
}

on the other hand suffers a net reduction in energy availability, receiving through allocation less than half of the savings achieved. Region I has essentially no-loss or gain.

\subsubsection{Air emission factors}

Fuel specific emissions data (tons/1012 Btu) by sector for petroleum fuels and natural gas were obtained from the SEAS data base ${ }^{9}$ and are shown in Table 4.21 for the three sectors of interest. These emissions factors are based on current data with the assumption of reasonable compliance with current regulations. This data base was used in a previous DOE/ERA study (Appendix F) to describe the environmental effects of mandatory building temperature restrictions. This is a conservation measure assumed to be part of the baseline case in the present study concerning restriction of commercial sector hours. In order to maintain consistency, the SEAS data base was therefore also utilized here. An alternate data base ${ }^{10}$ reflecting emission factors (by sector by fuel type)

9. The Strategic Environmental Assessment System was developed initially by the Environmental Protection Agency.

10. Environmental Characterizations for Energy Technologies and End Uses, USDOE, November 1978. 
Table 4.21. Air emission factors derived from SEAS data base (tons $/ 10^{12}$ Btu)

\begin{tabular}{|c|c|c|c|}
\hline Pullutant & Lommercial sector & Utility sector & Manufacturing sector \\
\hline \multicolumn{4}{|c|}{ Petroleum fuels } \\
\hline Particulates & 68.10 & 15.00 & 55.40 \\
\hline $\mathrm{SO}_{\mathrm{x}}$ & 361.00 & 504.00 & 421.00 \\
\hline $\mathrm{NO}_{x}$ & 207.00 & 357.00 & 253.00 \\
\hline Hydrocarbons & 10.40 & 6.99 & 10.40 \\
\hline Carbon monoxide & 13.90 & 10.49 & 13.90 \\
\hline \multicolumn{4}{|c|}{ Natural gas } \\
\hline Particulates & 4.85 & 4.85 & 7.28 \\
\hline $\mathrm{SO}_{\mathrm{x}}$ & 0.29 & 0.29 & 2.93 \\
\hline $\mathrm{NO}_{\mathrm{x}}$ & 58.20 & 175.80 & 336.00 \\
\hline Hydrocarbons & 3.88 & 1.45 & 0.48 \\
\hline Carbon monoxide & 9.70 & 8.24 & 8.25 \\
\hline
\end{tabular}

expected in future years could also have been used in this study. However, to maintain consistency, it would have been necessary to characterize the baseline environment with the same data base. Since this step of the analysis, with the inclusion of the temperature restriction measure, was outside the scope of this study, it was decided to use only the SEAS data. Notwithstanding the specific set of emissions data considered, the environmental impacts resulting from the reduced operating hours are not expected to be significant.

\subsubsection{Methodology to determine environmental impacts}

The regulation-induced reduction in the use of petroleum fuels and natural gas in the commercial and utility sectors, when multiplied by the appropriate emission factors, yields the reduction in the level of the criteria pollutants from these sectors. The use of these fuels in the manufacturing sector causes an increase in emissions which were similarly determined. The net changes in pollutant levels as a conse- 
quence of this shift in the pattern of fuel use are shown in Tables 4.17 and 4.18. As described earlier, savings in the utility use of coal were not assumed to be used elsewhere. This would, therefore, result in reduced emission levels for all of the criteria pollutants considered.

\subsubsection{Human factors aspect of regulation-induced environmental impacts}

The human factors aspect is an important consideration because regulation reducing commercial sector hours would directly affect employment, level of services, and patterns of consumer activities and would require accommodation to routines that would be different from normal. While a detailed analysis of this subject is beyond the scope of this study, a broad perspective of the issues involved is presented.

The social implications of a shortfall in energy and the imposition of mandatory temperature restriction have been dealt with elsewhere (ref. 2, Environmental Analysis). Briefly, the results indicate the following:

1. To the extent that the shortfall leads to a reduction in employment, the quality of life will be affected. The effects could be diffuse (if only a single sector of the economy such as the manufacturing sector is affected by the shortfall) or it could be pervasive if the shortfall curs across all sectors of the ecunviny.

2. Building temperature restrictions of $65^{\circ} \mathrm{F}$ in winter and $80^{\circ} \mathrm{F}$ in summer are consistent with standards set by OSHA, and the establishment of these levels would not bring about a significant decline in employee performance or productivity, although there would be some degree of discomfort experienced by building occupants.

3. It is difficult to predict the effects (if any) on the incidence of diseases and illness of building occupants, but they can be expected to be very small.

The imposition of additional regulations reducing the hours of operation of commercial establishments would have major effects: 
1. It would exacerbate the impact on the quality of life because it would lead to higher levels of unemployement (described in Sect. 4.3) and its attendant effects on individuals, families, and their social interactions. These effects would most likely be severe on people in the lower income groups, particularly in the large metropolitan areas where concentrations of commercial establishments are very high.

2. It would Impose changes, albeit temporary, on the normal shopping patterns of consumers, causing at least some inconvenience if not major readjustments and hardships.

3. If losses in tax revenues to government are substantial because of losses in incomes and sales of goods and services, they lead to either (a) a reduction in government services, which may have a more severe impact on people in the lower income groups, or (b) an increase in tax rates to compensate for revenue losses so that service levels can be maintained. It is also likely that because of increased unemployment, the demand for services such as crime prevention, medical and therapuetic services, and welfare services will increase. Should this occur, government expenditures will rise and tax rates may have to be increased to meet these costs.

The (adverse) impacts on the physical environment caused by shifts in the pattern of energy use were shown to be minor. Consequently, impacts on health are not expected to be an issue of major concern.

\subsection{Implementation}

If the emergency measure restricting hours of operation of commercial buildings were to be implemented, a number of issues and costs would have to be anticipated. This section describes some of these legal issues, enforcement and logistics problems, and implementation costs.

\subsubsection{Legal issues}

Appendix G provides a detailed listing of legal issues that may arise if a restriction on hours of operation of commercial establishments 
is imposed. Overall, none of the problems is unsurmountable, but the following four issues should be analyzed carefully before implementing the measure.

- Search warrants may be required for inspection of premises. This could hamper enforcement.

- "Equal protection" rights may present problems. The regulations must not result in grossly unequal impacts on different members of the same class of establishment.

- Labor contracts generally specify layoff procedures. Emergency regulations that lead to temporary layoffs shuuld be considered by employers and employees.

- If a state were successful in saving an energy resource as a result of the regulation, it would not be able to use the saved energy in-state if other regions were in greater need. This would probably diminish state support for the measure.

\subsubsection{Other implementation problems}

Enforcement of the emergency measure must be carried out rigorously and impartially if appreciable energy is to be saved. 'lihe following issues and problems should be resolved:

- DOE staff and state governors must specify channels of communication so thät questions regarding the regulations may be answered quickly and accurately.

- State officials should hold training workshops for inspectors and enforcement officers. This is a time-consuming process.

- Each state (or DOE) must set up an appeàls process to hear cumplaints from establishments that feel they have been dealt with unfairly. For example, the high hunidity assoniated with high summer temperatures may be harmful to trade goods in certain commercial establishments, and these establishments will appeal the measure.

- Officials need to define operationally a "trigger point" that would be used to initiate the measure. 
Logistical problems associated with the preparation and distribution of public information materials should be anticipated. If the proprietors of the establishments and the general public understand the regulations and the reasons for the regulations, a higher degree of cooperation should result. The following procedures should be completed well before the measure is implemented.

- DOE staff should obtain clearance for any forms that need to be used.

- DOE staff should prepare copies of the regulations, copies of brochures providing hints as to minimizing adverse impacts, and copies of training manuals for enforcement officers.

- DOE and state officials should prepare newspaper, radio, and TV releases explaining the evidence for the crists and the rationale of the emergency measure.

A well-planned monitoring and evaluation system should be implemented as part of the emergency measure. In this way, actions that are successful may be identified and made ready for future emergencies, and actions that proved of little use may be discarded.

\subsubsection{Implementation costs}

The authors have not made a direct study of the costs involved in implementing this conservation plan. Rough estimates of implementation costs may be made, however, by reference to two related studies (see Table 4.22).

Even if the EBTRP estimate is adjusted for 12 months, making the total about $\$ 11$ million, the two estimates differ by almost $3: 1$. Both estimates were made assuming the plan would be implemented independently. The ERC plan assumes that enforcement will be difficult, since the measure will probably be unpopular both with commercial people and the general public. A large number of inspectors would be required to monitor thermostat settings and hours of closure.

If the measure to restrict hours of operation were implemented independently, the authors feel that the higher estimate by ERC, which includes much more adequate staffing, would be more appropriate. If the 
Table 4.22. Estimates of implementation costs from re-ited studies

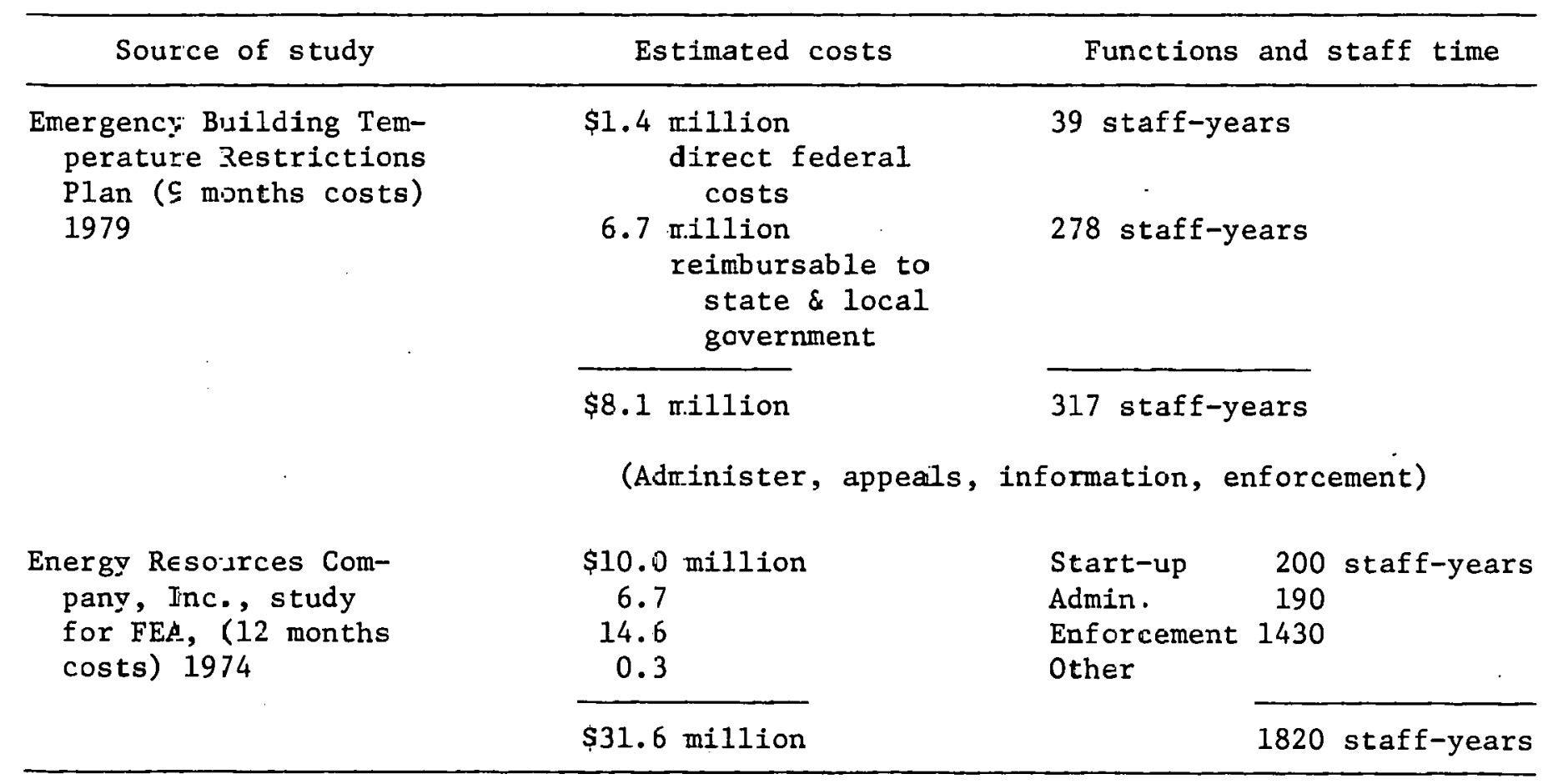

Sources: A Study of the Impact cf Reduced Retail Store Operating Hours on Sales, Employmer.t, Economic Concentraticn, and Energy Consumption, Energy Resources Company, Inc., 1975. Standby Conserycticr PZar Nc. 2 - Emergency Building Temperature Restriction, U. .. Department of Energy, 1979. 
ERC estimate were corrected for about five years of inflation, it would require about $\$ 45$ million to field the same staff time. Obviously, the measure could be enforced and implemented at any degree of rigor, but any serious approach would probably cost at least $\$ 35$ to 50 million. Thesc catimates do not include costs to the private (commercial) sector. If the measure were implemented as an "add on" or companion to the EBTRP, the costs could be shared. Appendix H contains the "Authorities Need, Rationale, Operation" information that would be required if the measure were selected by ERA for possible implementation. 
Appendix A

POSSIBLE EMERGENCY ENERGY (PETROLEUM) CONSÉRVATION MEASURES:

AN INITIAL LIST FOR SCREENING

\section{A.1 Emergency conservation measures for residential buildings}

- Reduce thermostat setting $6^{\circ} \mathrm{F}$ in winter (to about $68^{\circ} \mathrm{F}$ ); additional reduction of $8^{\wedge} \mathrm{F}$ at night.

- Set up thermostat $6^{\circ} \mathrm{F}$ in summer (to about $78^{\circ} \mathrm{F}$ ).

- Reduce water heater setting about, $25^{\circ} \mathrm{F}$ (from about $145^{\circ} \mathrm{F}$ to $120^{\circ} \mathrm{F}$ ).

- Reduce hot water used in bathing by one-third.

- Stop use of hot water for laundry.

- Reduce infiltration with polyethylene sheets over windows; caulk cracks.

- "Tune up" oil furnace burners.

- Power substitution in areas where electricity is generated from coal, hydro, or nuclear - not oil (greater use of electric or wood space heaters and less use of furnace oil).

- Reduce electric power use in regions where electricity is generated from oil. (Restrict cooking and oven use; restrict use of clothes dryers.)

- Reduce electric power use by reducing voltage or rotating blackouts.

- Use heavy curtains to close off windows at night and open to admit sun during day.

- Early cutoff of TV broadcasts so people will not stay up late and keep house heated.

- Neighbors share houses and "close down" one house; close down private residences and set up emergency centers (in case of extreme emergency). 
A.2 Emergency conservation measures for commercial buildings

- Adjust thermostat settings

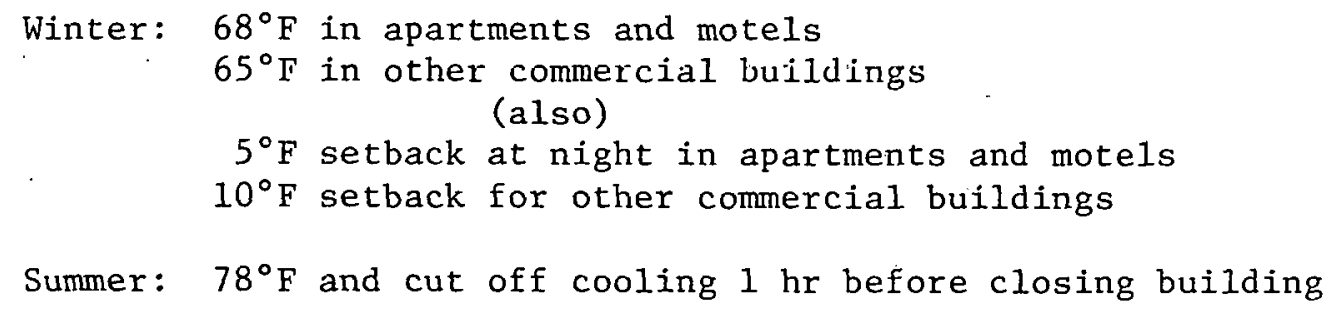

- Reduce lighting in the summer to minimum acceptable level.

- Reduce temperature of gencral-purpose hot water $20^{\circ} \mathrm{F}$ (to about $120^{\circ} \mathrm{F}$ ).

- Establish minimum air ventilation during occupancy and zero ventilation when unoccupied.

- Tune up oil burner to best efficiency.

- Revise school year and eliminate evening classes.

- Cancel evening public activities.

- Shut down nonessential commercial operations and compensate owners and workers.

- Restrict commercial business hours.

- Mandatory vacation shutdown.

- Reduce space used (and heated) in a building.

- Cut back electrical power delivered to commercial buildings.

- Reduce street lighting by half. 
A. 3 Emergency conservation measures for commercial transportation Trucks

- Improve maintenance and operating procedures - less empty hauling, direct routings, tuned engincs, etc.

- Increase weight limits -

$$
\begin{array}{ll}
\text { single axle } & 18,000 \mathrm{lb} \text { to } 20,000 \mathrm{lb} \\
\text { tandem axle } & 32,000 \mathrm{lb} \text { to } 34,000 \mathrm{lb} \\
\text { gross weight } & 73,280 \mathrm{lb} \text { to } 78,000 \mathrm{lb}
\end{array}
$$

- Enforce 55-mph limit on intercity trucking.

- Reduce use of government trucks.

- Shift from truck to barge or rail where feasible.

- Insulate truck fuel lines in northern states so they can use No. 2 diesel without mixing in No. 1 diesel used in home heating.

\section{$\underline{\text { Barge }}$}

- Increase operating efficiencies by speed reduction and shorter turnaround time.

\section{Commerc1a1 air}

- Increase load factor from $50 \%$ to $70 \%$ to decrease number of flights.

- Shift $50 \%$ of the short air hops ( $<200$ miles) to bus.

- Reduce cruise speeds and increase cruise altitude to minimize fuel used instead of cost.

- Tow planes on ground.

- Fly direct routes.

- Reduce military training flights by using simulators.

- Use phone instear nf flying.

- Segregate landing areas for fast-landing commercial planes and slower-landing private planes. 
Appendix B

REVIEW OF EMERGENCY CONSERVATION MEASURES

Including Group Recommendations

\section{B. 1 Residential buildings}

Reviewers: R. M. Davis, Roger Carlsmith, Eric Hirst

- Reduce thermostat setting $6^{\circ} \mathrm{F}$ in winter (to about $68^{\circ} \mathrm{F}$ ); additional reduction of $8^{\circ} \mathrm{F}$ at night; set up thermostat $6^{\circ} \mathrm{F}$ in summer (to about $78^{\circ} \mathrm{F}$ ).

Recommendation: Review further; could show significant savings; minimum economic impact; difficult to enforce

- Reduce water heater setting about $25^{\circ} \mathrm{F}$ (from about $145^{\circ} \mathrm{F}$ to $120^{\circ} \mathrm{F}$ ); reduce hot water used in bathing by $1 / 3$; stop use of hot water for laundry.

Recommendation: Review further, minimum economic impact; difficult to enforce

- Reduce infiltration with polyethylene sheets over windows; caulk cracks.

Recommendation:- Review further, question availability of supplies; difficult to enforce

- "Tune up" oil furnace burners.

Recommendation: Review further, question technical manpower needed; difficult to enforce

- Power substitution in areas where electricity is generated from coal, hydro, or nuclear - not oil (greater use of electric space heaters and less use of furnace oil).

Recommendation: Delete; lack of space heaters; demand on generating equipment; difficult to assess economic impact, supplies of other fuels, enforcement

- Reduce electric power use in regions where electricity is generated from oil. (Restrict cooking and oven use; restrict use of clothes dryer.)

Recommendation: Delete except in extreme emergency; little savings; symbolic measure 
- Reduce electric power use by reducing voltage or rotating blackouts.

Recommendation: Deleted as nationwide measure. Additional analysis desirable for regions where electricity is generated from oil.

- Use heavy curtains to close off windows at night and open to admit sun during day.

Recommendation: Review further; minimum economic impact; difficult to enforce

- Early cutoff of TV broadcasts so people will not stay up late and keep house heated.

Recommendation: Delete; heavy social impact, although this measure reoulted in oaving on home heating in other countries; économic impact from reduced advertising

- Neighbors share houses and "close down" one house; close down private residences and set up emergency centers.

Recommendation: Delete; difficult to implement; difficult to assess savings; unpopular as an invasion of privacy; minimum economic impact

Additions to list of measures from Review Group:

- Closing rooms in homes.

Kecoumendation: Review further; minlmum economlc impacl; difficult to enforce

- Curtail oil supplies to residences; allocation.

Recommendation: Retain as possible mandatory measure; assures a predetermined percentage savings 


\section{B.2 Commercial buildings}

Reviewers: R. M. Davis, R. S. Carlsmith, Eric Hirst

- Adjust thermostat settings.

Winter: $68^{\circ} \mathrm{F}$ in apartments and motels

$65^{\circ} \mathrm{F}$ in other commercial buildings

$$
\text { (also) }
$$

$5^{\circ} \mathrm{F}$ setback at night in apartments and motels

$10^{\circ} \mathrm{F}$ setback for other commercial buildings

Summer: $78^{\circ} \mathrm{F}$ and cut off cooling $1 \mathrm{hr}$ before closing building

Recommendation: Further reviews desirable; potential for significant savings; enforcement problems generally less than for residential; economic impact not great; health and safety impact a problem in motels and apartments

- Reduce lighting to minimum acceptable level.

Recommendation: Current government requirements for public buildings already in effect; further reduction primarily symbolic; enforcement difficult

- Reduce temperature of genera1-purpose hot water $20^{\circ} \mathrm{F}$ (to about $\left.120^{\circ} \mathrm{F}\right)$.

Recommendation: Further review desirable; potential for some savings; little economic impact; enforcement could be difficult; exemptions necessary in specialized cases

- Establish minimum air ventilation during occupancy and zero ventilation when unoccupied.

Recommendation: Delete as mandatory measure; difficult to engineer and enforce; potential for savings

- Tune up oil burner to best efficiency.

Recommendation: Further review desirable; manpower requirements, ease of enforcement are questions; potential for savings

- Revise school year and eliminate evening classes.

Recommendation: Delete; potential for saving; large social impact 
- Cancel evening public activities.

Recommendation: Delete; potential for saving; large economic and social impact

- Shut down nonessential commercial operations and compensate owners and workers.

Recommendation: Delete; subjective judgments required for "nonessential." "Compensation" difficult to administer and expensive to fund.

- Restrict commercial business hours.

Recommendation: Yotential for sàing; slzable economlc 1mpact; enforceable

- Mandatory vacation shutdown.

Recommendation: Delete; unfair economic impact on some businesses

- Reduce space used (and heated) in a building.

Recommendation: Cannot be mandatory; potential for savings; little economic impact

- Cut back electrical power delivered to commercial buildings.

Recommendation: Further technical reviews needed

- Reduce street lighting by half.

Recommendation: Further review desirable; little economic impact; probable social impact (rise in crime rate?); a symbolle measure

Measures added by reviewers:

- Allocation of petroleum to the commercial sector.

Recommendation: Further review desirable; would assure percentage saving of petroleum; enforceable 


\section{B.3 Commercial transportation}

Reviewers: R. M. Davis, R. S. Carlsmith, D. G. Greene, A. B. Rose

\section{Trucks}

- Improve maintenance and operating procedures - less empty hauling, direct routings, tuned engines, etc.

Recommendation: Delete; in general, truckers are already doing this

- Increase weight limits -

$$
\begin{array}{lll}
\text { single axle } & 18,0001 \mathrm{~b} \text { to } 20,000 \mathrm{1b} \\
\text { tandem axle } & 32,000 \mathrm{lb} \text { to } 34,000 \mathrm{bb} \\
\text { gross weight } & 73,2801 \mathrm{~b} \text { to } 78,0001 \mathrm{~b}
\end{array}
$$

Recommendation: Combine with recommendation to allow double and triple trailers plus enforcement of 55 -mph speed to make package that would be economically acceptable for truckers; impact on roads needs further review; "borrows energy from future for road repair"; safety questions

- Enforce 55-mph limit on intercity trucking.

Recommendation: See weight limit recommendation; resistance by truckers if other trade-offs not given

- Reduce use of government trucks.

Recommendation: Include as symbolic measure; 1ittle opportunity for significant savings

- Shift from truck to barge or rail where feasible.

Recommendation: Delete; already being used where applicable

- Insulate truck fuel lines in northern states so they can use No. 2 diesel without mixing in No. 1 diesel used in home heating.

Recommendation: Delete; specific to a few northern regions; does not conserve; only changes types of fuel used 


\section{Barge}

- Increase operating efficiencies by speed reduction and shorter turnaround time.

Recommendation: Additional technical review needed.

\section{Commercial air}

- Increase load factor from $50 \%$ to $70 \%$ to decrease number of flights.

Recommendation: Delete; load factors already at 70\%; load factor up $10 \%$ this year since deregulation

- Shift $50 \%$ of the short air hops ( $<200$ miles) to bus.

Recommendation: Additional technical review needed. Buses use $10 \%$ of energy of planes on short trips; there is availahle caparity on buses. May not increase savings as much as expected, since short-hop plane passengers may be filling out long-hop empty seats.

- Reduce cruise speeds and increase cruise altitude to minimize fuel used instead of cost.

Recommendation: Delete; already being done; cruise speeds have been reduced; safety is a determinant fur altitude

- Tow planes un gruund.

Recommendation: Delete; safety and lack of equipment are considerations; may require longer waits in air for landing

- F1y direct routes.

Recommendation: Delete; safety considerations

- Reduce military training flights by uslug slmulacors.

Recommendation: Delete; already being done to some extent. (Could be included as area of review by military.)

- Use phone instead of flying.

Recommendation: Delete; no way to assess savings; could be part of PR campaign for emergency savings 
- Segregate landing areas for fast-landing commercial planes and slower-landing private planes.

Recommendation: Delete; in-place facilities a problem

Reviewers additions:

- Ground general aviation except for necessary flights (crop dusting, air ambulance, etc.).

Recommendation: Potential energy saving; travelers could be accommodated; economic impact on charter plane owners 
Appendix C

A REDUCED LIST OF PROPOSED MEASURES TO DECREASE PETROLEUM CONSUMPTION

C.1 Residential buildings

$\underline{\text { Measure }}$

Mandatory:

- Allocation of available supplies to assure a predetermined percentage saving of the supply

- Voltage reduction plus rotating blackouts, depending on severity of shortage. (Used in regions heavily dependent on oil for electricity generation.)

Voluntary:

- A combination of the following -

Reduce thermostat settings to $66^{\circ} \mathrm{F}$ in winter and to $58^{\circ} \mathrm{F}$ at night; increase thermostat settings to $78^{\circ} \mathrm{F}$ in summer

Reduce use of hot water by reducing hot-water heater setting to $120^{\circ} \mathrm{F}$ and stop use of hot water in laundry

Space condition house by reducing infiltration (polyethylene sheets

and drapes), caulking cracks

Tune up oil furnace burners
Approximate savings

$\%$ saved predetermined by $\%$ allocation

Saving unknown

$0.3-0.8$ quad

$<0.1$ quad

$0.2-0.4$ quad
Committee recommendations

Review conservation measures to determine a "reasonable" \% allocation that could be met using conservation measures

Additional technical review needed

Retain measure; National Petroleum Council had data on estimated achievable savings for those temperatures

Retain measure; dificult to assess reduction in hot-water use in laundry; urge as supplemental conservation measure

Retain measures

Retain measures 


\section{2 Commercial buildings}

$$
\text { Measure }
$$

Mandatory

- Allocation of available supplies to assure a predetermined percentage saving of the supply

- Voltage reduction filus rotating blackouts, depending on sererity of shortage. (Used ic regions heavily dependent :n oil for electricity generation.)

\section{Mandatory or joluntary:}

- Establish $\Xi 68^{\circ} \mathrm{F}$ meximum o:cupied temperatur $=1$ level in apartments and hotels and motels in commercial

establishments (hospitals and nursing homes excepted)

Establish $\equiv 5^{\circ} \mathrm{F}$ night setback below day levels in apartments and $10^{\circ} \mathrm{F}$

for commercial buildings diring unoccupied hours; hospitalis and nursing homes excepted

Establish zooling comfort level of $78^{\circ} \mathrm{F}$. Cut off cooling $\mathrm{l} \mathrm{hr}$

before occupants leave

- Restrict hours of operation for commercial businesses
$\%$ saved predetermined

by $\%$ allocations

Saving unknown

0.4 quad
0.2 quad
0.1 quad

0.3 quad
E.eilew ccnservation measures to ¿termine a "reasonable" \% allocation th:t could be met using conservation zeasures

Eciditionel technical review needed
Eetain sface conditioning measures

Eetain as conservation measure 


\section{C.3 Commercial transportation}

Measure

Mandatory

- Allocation of avallable supplies to assure a predetermined percentage saving of the supply

Commercial trucking:

- A combination of the following -

1. Increase welght limits Single axle

$18,000 \mathrm{Ib}$ to $20,000 \mathrm{lb}$

Tandem axle

$32,0001 \mathrm{~b}$ to $34,0001 \mathrm{~b}$

Gross weight

$73,2801 \mathrm{~b}$ to $78,000 \mathrm{lb}$

2. Do:sble or triple bottoms

3. Enforce 55-mph limit on intercity trucking

- Reduce use of government trucks $10-20 \%$

Domestic water-borne commerce:

- Speed reduction of $10-15 \%$

Commerciai air transportation:

- Cancel short alr hops (<200 niles); shift to bus

- Ground general aviation planes except on essential services such as air ambulance, crop dusting
Committee recommendations
$<0.1$ quad

$\%$ saved predetermined

by $\%$ allocation

0.03 quad

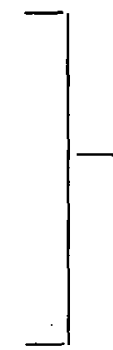

$0.1-0.2$ quad

$<0.1$ quad

0.1 quad

0.1 quad
Retain as suggested measure

Delete because of road wear; safety; laws in some states
Retaln as symbolic measure

Delete; small savings; difficult enforcement

Delete; many shifts would be to private car rather than bus, decreasing savings; considerable inconvenience

Delete; falls under study by another agency for ERA 


\section{Appendix D \\ SIMULATION OF ECONOMY IN THE ABSENCE OF REGULATION \\ (BASELINE ECONOMY)}

The baseline economy represent's the U.S. economy after the onset of a hypothetical interruption of $1.6 \mathrm{million}$ bbl/day in the imported supply of crude oil, lasting from the fourth quarter of 1980 through the third quarter of 1981. This interruption represents a loss of approximately $10 \%$ of total U.S. crude consumption expected over the 1980-81 period. In response to the interruption, mandatory restrictions on the temperature levels of selected public and private buildings are assumed to be enforced. The temperature restriction measure is expected to reduce energy demand by 1.0 million bbl/day crude oil equivalent* and moderate the impact of the interruption to a net level of 0.6 million $\mathrm{bbl} / \mathrm{day}$. The net shortfall in crude supplies is assumed to impact only the manufacturing sector, causing a decline in that sector's output. In addition, a modest increase in domestic energy prices is expected during the duration of the supply interruption.

The baseline economy was simulated using the Data Resources Inc. (DRI) mode1 of the U.S. economy, Trendlong 03/79, with changes in three variables shown in Table $D-1$ corresponding to the assumptions described.

The decline in the value of fuel imports reflects the loss of $1.6 \mathrm{million} \mathrm{bbl} / \mathrm{day}$ of crude oil at an average price of $\$ 2.60$ per barre 1 in 1967 dollars. The increase in domestic energy prices was assumed and reflected through an annual rate of increase in the wholesale price index for fuels, $10 \%$ higher than that shown in Trendlong $03 / 79$. The shortfall-induced decline in the index of industrial production and manufacturing (JQINDM) was derived as follows. The index was correlated

\footnotetext{
${ }^{*}$ Based on data from ref. 1, considering reductions in demand, direct and indirect, for petroleum fuels and natural gas under mandatory imposition of thermostat settings of $65^{\circ} \mathrm{F}$ in winter and $80^{\circ} \mathrm{F}$ in summer from a year-round normal setting of 72 to $73^{\circ} \mathrm{F}$. Reference 1 considers a shortfall in petroleum supplies that is $15 \%$ of U.S. petroleum consumption. In response to this shortfall, voluntary conservation measures are first assumed to be implemented leading to thermostat settings of $68^{\circ} \mathrm{F}$ in winter and $77^{\circ} \mathrm{F}$ in summer from a year-round normal setting of 72 to $73^{\circ} \mathrm{F}$. The imposition of mandatory temperature restrictions is then assumed which requires thermostat settings to be further lowered to $65^{\circ} \mathrm{F}$ in winter and raised to $80^{\circ} \mathrm{F}$ in summer. The petroleum and natural gas savings induced solely as a result of the regulation are estimated to be about $0.5 \mathrm{million}$ bbl/day. If the petroleum and natural gas savings from the voluntary action are also taken into account, ref. 1 estimates the total energy savings to be about $1 \mathrm{mlllion}$ bbl/day (see Sects. 1.3 and 2.1 of ref. 1 for further details, particularly the caveat on the top of p. 1.2).
} 
with manufacturing industry shipments (SM) directly associated with value added ( $V$ ). In turn, value added and energy use in manufacturing (E) can be correlated. Consequently, an empirical relationship between the index and energy consumption is obtained. Equations (1) through

(3) show the form of the calculation:

$$
\left(\mathrm{JQINDM}_{i}=\mathrm{a}+\mathrm{b}(\mathrm{SM})_{i}\right. \text {, }
$$

where

$$
\begin{aligned}
i & =\text { quarterly time period, } \\
\mathrm{a} & =0.21630, \\
\mathrm{~b} & =0.00495, \\
\mathrm{SM} & =\text { industry shipments in billions of } 1972 \$ .
\end{aligned}
$$

The linear-regreecion form of Eq. (1) was derived usilly lutrlerly data from 1970 through 1978 for JQINDM and SM (from the DRI data bank) and applied to the 1980-81 time period.

In step 2 of the calculation, value added in manufacturing was related to SM according to $\mathrm{Eq}$. (2), using recent historical data: ${ }^{2}$

$$
(2.33) \cdot V=S M
$$

where

SM and $\mathrm{V}$ are in constant 1972 \$.

The ratio $(\mathrm{V} / \mathrm{E})$ of value added in manufacturing per unit of energy consumption, or its converse, is otten cited as a measure of the energy effectiveness of industrial operations (see, for example, "Energy Consumption in Manufacturing," Ford Foundation Study, Ballinger Publishing Co., 1974). The statistics for 1.976 (refs. 3 and 4) show the following:

value added in manufacturing $(V)=\$ 382.4$ billions of $1972 \$$, energy consumption in manufacturing $(E)=12.77$ quads, $(\mathrm{V} / \mathrm{E})_{1976}=\$ 30 / \mathrm{mi} 11$ ion Btu.

Assuming this value of ( $V / E$ ) to be (roughly) constant nver the 1980-81 time period, the change in JQINDM resulting from a change in energy available to the manufacturing sector can be derived as follows:

$$
\begin{aligned}
(\triangle \mathrm{JQINDM}) & =\mathrm{b} \cdot \Delta S \mathrm{SM} \\
& -\mathrm{b} \cdot(2.33) \cdot \Delta \mathrm{V} \\
& =\mathrm{b} \cdot(2.33) \cdot(30) \cdot(\Delta \mathrm{E}),
\end{aligned}
$$

where

$$
\begin{aligned}
\Delta E= & \text { change in energy availability (quads) } \\
& \text { to the manufacturing sector in each quarter } \\
& \text { between } 1980: 4 \text { and } 1981: 3 . \Delta E \text { can be positive } \\
& \text { or negative. }
\end{aligned}
$$


Equation (3) has to be interpreted with some caution. JQINDM is a production index not a production function. Consequently, interpreting the relationship shown from an "elasticity" concept may not be appropriate. For example, under an energy supply shortfall, energy consumption can be reduced (through leak plugging and belt tightening, if such measures have not been accomplished even as part of normal operations) without affecting output. Conversely, even with very energy efficient operations, any increase in energy availability other than in an existing shortfall situation cannot be translated through Eq. (3) into a corresponding increase in output, since energy is only one factor of production.

The validity of $\mathrm{Eq}$. (3) is best reflected when

- industrial operations are at peak (or close to peak) efficiency from an energy utilization standpoint,

- a small to moderate energy shortfall exists which does cause a reduction in the level of industrial operations.

Under the assumption that the value of $(V / E)$ considered herein is at least approximately representative of condition (1) cited above, Eq. (3) is a reasonable correlation between JQINDM and E.

Selected measures of economic activity in the baseline economy are shown in Table D-2. They represent conditions from which regulationinduced changes in the economy will be determined.

Table $D-1$. Variables influencing baseline economy

$$
\begin{aligned}
& \mathrm{A} \text { - DRI/Tiendlung 03/79 } \\
& \mathrm{B}=\text { baseline economy }
\end{aligned}
$$

Variables

Time period

$1980: 4 \quad 1981: 1 \quad 1981: 2 \quad 1981: 3$

- Value of imports of fuels and lubricants (billions of $1967 \$$ )
A
8.3
8.2
8.3
8.2
B
6.8
6.7
6.8
6.7

- Index of industrial production-manufacturing sector $(1967-1.00)$

$\begin{array}{lllll}\text { A } & 1.563 & 1.592 & 1.610 & 1.619 \\ \text { B } & 1.449 & 1.478 & 1.496 & 1.505\end{array}$

B

- Wholesale price index - fuels, related products, and power (1967 - 100)

1.505

$\begin{array}{lllll}\text { A } & 4.445 & 4.569 & 4.696 & 4.825 \\ \text { B } & 4.543 & 4.771 & 5.009 & 5.259\end{array}$


Table D-2. Selected measures of economic activity in baseline economy

\begin{tabular}{lllll}
\hline Variables & \multicolumn{4}{c}{ Time period } \\
\cline { 2 - 5 } & $1980: 4$ & $1981: 1$ & $1981: 2$ & $1981: 3$ \\
\hline
\end{tabular}

- Gross national product (billions of $1972 \$$ )

$$
1488.0 \quad 1504.9 \quad 1514.3,1522.1
$$

- Personal consumption expenditures (billions of 1972 \$)

$$
\begin{array}{llll}
962.1 & 973.9 & 981.8 & 988.4
\end{array}
$$

- Gross private domestic fixed investment (billions of 1972 \$)

$$
210.3 \quad 213.8 \cdot 216.1216 .3
$$

- Change in business inventories (billions of 1972 \$)

$$
9.8 \quad 11.3 \quad 4.4 \quad 9.6
$$

- Disposable personal income (billions of 1972 \$)

$$
1065.9 \quad 1071.7 \quad .1077 .9 \quad 1088.5
$$

- Total employed (millions)

$$
\begin{array}{llll}
98.9 & 99.7 & 100.4 & 101.0
\end{array}
$$

- Consumex price index - urban (1972 - 1.00)

$\begin{array}{llll}2.354 & 2.399 & 2.445 & 2.491\end{array}$




\author{
Appendix E \\ SIMULATION OF ECONOMY UNDER REGULATION \\ (REGULATED ECONOMY)
}

\title{
E.1 Introduction
}

The economy under regulation was simulated for two levels of curtailment in operating hours, namely, 60 and $40 \mathrm{hr} /$ week. In each instance, the magnitude of a loss in sales was varied between zero and a level determined in proportion to the reduction in operating hours for selected establishments. Notwithstanding the sales effect, a reduction in operating hours is expected to result in:

- A reduction in total man-hours through a combination of layoffs and shortened work hours leading to an aggregate loss in personal income and its attendant effects (employment-income effect).

- Energy savings in the commercial sector which are then assumed to be used in the manufacturing sector (energy effect).

Each of these outcomes was estimated and used as external inputs to the DRI model to affect the baseline economy.

\section{E.1.1 Determination of sales effect}

Commercial sector establishments likely to be impacted by regulation of operating hours are shown in Table $\mathrm{E}-1$. In the case where sales are assumed to be affected, only the following five establishments are expected to incur a loss in sales and revenues (see Sect. 4.3):

- General merchandise

- Apparel and accessories

- Eating and drinking

- Other retail

- Other services

The level of sales and revenues in 1980-81 estimated nationally for these five establishments in the baseline economy is shown in Table E-2. These sales were projected from corresponding levels in 1977 at annual growth rates equal to average rates experienced between 1972 and 1977.1

The loss in sales incurred by each establishment, assuming a proportionality factor of 0.25 , is shown in Table E-3 (i.e., a $1 \%$ reduction in hours is associated with a $0.25 \%$ reduction in sales).

The loss in sales shown in Table $\mathrm{E}-3$ range approximately from $1 \%$ (in the $60-\mathrm{hr}$ week) to $3.3 \%$ (in the 40-hr week) of total sales in the retail trade and services sectors, which in the 1980:4 to 1981:3 time period was determined to be $\$ 1240$ billion. 
Table E-1. Cormercial sector establishments affected by regularior limiting hours of operation ${ }^{a}$

\begin{tabular}{|c|c|c|c|c|c|}
\hline \multirow{2}{*}{$\begin{array}{l}\text { Categories of } \\
\text { business } \\
\text { establishments }\end{array}$} & \multirow{2}{*}{$\begin{array}{l}\text { Days of } \\
\text { operation }\end{array}$} & \multirow{2}{*}{$\begin{array}{l}\text { Hours of } \\
\text { operation }\end{array}$} & \multirow{2}{*}{$\begin{array}{l}\text { Hours } \\
\text { per week }\end{array}$} & \multicolumn{2}{|c|}{$\begin{array}{l}\text { Percent reduction in hours } \\
\text { per week under regulation }\end{array}$} \\
\hline & & & & $\begin{array}{l}\text { With } 60 \mathrm{hr} \\
\text { per week }\end{array}$ & $\begin{array}{c}\text { With } 40 \mathrm{hr} \\
\text { per week }\end{array}$ \\
\hline $\begin{array}{l}\text { Building materials, } \\
\text { hardware, etc. }\end{array}$ & Mon.-Sat. & $9-5$ & $\dot{48}$ & & 16.7 \\
\hline General merchandise & Mon.-Sat. & $9-9$ & 72 & 16.7 & 44.4 \\
\hline Food & Mon.-Sat. & $10-10$ & 72 & 16.7 & 44.4 \\
\hline Automotive dealers & Mon.-Sat. & $9-6$ & 54 & & 25.9 \\
\hline $\begin{array}{l}\text { Gasoline service } \\
\text { stations }\end{array}$ & Sun.-Sat. & $7-10$ & 105 & 42.9 & 61.9 \\
\hline Apparel $\hat{\alpha}$ Accessories & Mon.-Sat. & $9-9$ & 72 & 16.7 & 44.4 \\
\hline Furniture & Mon.-Sat. & $\pm 0-8$ & 60 & & 33.3 \\
\hline Eating \& drinking & Sun.-Sat. & $=0-10$ & 84 & 28.6 & 52.4 \\
\hline Drug stores & Sun. - Sat. & $9-9$ & 84 & 28.6 & 52.4 \\
\hline Other retail & Mon.-Sat. & $9-6$ & 54 & & 25.9 \\
\hline Personal services & Mon_-Sat. & $9-9$ & 72 & 16.7 & 44.4 \\
\hline Other services & Mon.-Sat. & $9-6$ & 54 & & 25.9 \\
\hline
\end{tabular}

\footnotetext{
$a_{\text {See ref. } 8 .}$
} 
Table E-2. Annual sales and revenues in selected commercial establishments in the baseline economy

\begin{tabular}{|c|c|c|}
\hline \multirow[t]{2}{*}{ Establishments } & \multicolumn{2}{|c|}{$\begin{array}{l}\text { Sales and revenues }{ }^{a} \\
\text { (billions of current } \$ \text { ) }\end{array}$} \\
\hline & 1980 & 1981 \\
\hline General merchandise & 112.4 & 121.4 \\
\hline Apparel \& accessories & 40.9 & 43.7 \\
\hline Eáting \& drinking & 89.6 & 100.4 \\
\hline Other retail & 65.9 & 72.1 \\
\hline Other services & 81.7 & 92.1 \\
\hline
\end{tabular}

Table E-3. Loss in sales and revenues in selected commercial establishments from reduced operating hours (quarterly at annual rates)

\begin{tabular}{|c|c|c|c|c|}
\hline \multirow{2}{*}{ Establishments } & \multicolumn{4}{|c|}{$\begin{array}{l}\text { Loss in sales and revenues } \\
\text { (billions of current } \$ \text { ) }\end{array}$} \\
\hline & $1980: 4$ & $1981: 1$ & $1981: 2$ & $1981: 3$ \\
\hline \multicolumn{5}{|c|}{ 60-hr week } \\
\hline General merchandise & 4.7 & 5.1 & 5.1 & 5.1 \\
\hline Apparel $\&$ accessuries & 1.7 & 1.8 & 1.8 & 1.8 \\
\hline Eating \& drinking & 6.4 & 7.2 & 7.2 & 7.2 \\
\hline Othér relall & & & & \\
\hline Other services & & & - & -1 \\
\hline Total & 12.8 & 14.1 & 14.1 & 14.1 \\
\hline \multicolumn{5}{|c|}{ 40-hr week } \\
\hline General merchandise & 12.5 & 13.5 & 13.5 & 13.5 \\
\hline Apparel \& accessories & 4.5 & 4.9 & 4.9 & 4.9 \\
\hline Eating \& drinking & 11.7 & 13.2 & 13.2 & 13.2 \\
\hline Other retail & 4.3 & 4.7 & 4.7 & 4.7 \\
\hline Other services & 5.3 & 6.0 & 6.0 & 6.0 \\
\hline Total & 38.3 & 42.3 & 42.3 & 42.3 \\
\hline
\end{tabular}




\section{E.1.2 Determination of employment income effect}

Man-hours, wage rates, and employment in the business establishments likely to be affected by regulation are shown in Table E-4 for the baseline economy, considering just the nonsupervisory work force. The first ten of these establishments constitute all retail trade. The "other services"t category is selective because it excludes hotels, motels, health services, certain business services, motion picture production, etc., which are assumed to be unaffected by the regulation.

The wage rates during $1980-81$ in each establishment were obtained with 1977 data $^{5}$ projected using quarterly implicit price deflators for GNP obtained for the baseline economy from the DRI model (i.e., no real increases in wages were considered).

Employment by establishments in retail trade and services were derived as follows:

Employment in retail trade alone was assumed to be $78 \%$ of that in retail and wholesale trade, 5 which is what is projected in the DRI model. of those employed in retail trade, $88 \%$ were assumed to be in nonsupervisory roles ${ }^{5}$ representing approximately 14 million persons in the $1980-81$ time period. Disaggregation of this work force between the ten establishments in retail trade was based on the employment distribution in 1977, 5 which was assumed to remain unchanged through 1981.

The DRI model projects total employment in the services category. The nonsupervisory work force in services is assumed to be $89 \%$ of the total, 5 of which $2.5 \%$ is in the "personal services" category and $8.5 \%$ in the "other services"t category. 5

The average annual hours worked per nonsupervisory employee in the establishments shown in Table $\mathrm{E}-4$ were assumed to remain unchanged from the levels in 1977, although the Bureau of Labor Statistics data show a declining trend due to a significant increase in part-time employees currently estimated at over $50 \%$ of the labor force in these establishments. ${ }^{6}, 7$

The reduction in operating hours enforced by regulation is assumed to lead to reduction in man-hours through a combination of layoffs and shortened work hours. The ultimate effect is a loss in personal income, which in turn leads to a decrease in consumption with its attendant effects.

The total quarterly loss in personal income at annual rates across al1 affected establishments, over the period 1980:4 to 1981:3, is shown in Table E-5 for both the 60- and 40-hr-week operations. The income loss is derived as follows:

\footnotetext{
†Includes miscellaneous repair services, automotive repair, garages, amusement, and recreation services including motion picture theatres, etc.
} 
Table E-4. National average man-hours, wage rates, and employment in business establishments affected by regulation (data for baseline economy)

\begin{tabular}{|c|c|c|c|c|c|c|c|c|c|}
\hline \multirow{2}{*}{$\begin{array}{l}\text { Categories of } \\
\text { business } \\
\text { establishments }\end{array}$} & \multirow{2}{*}{$\begin{array}{l}\text { Normal average } \\
\text { annual hours } \\
\text { worked/emplogee } \\
\text { (nonsupervisory } \\
\text { Employees) }\end{array}$} & \multicolumn{4}{|c|}{$\begin{array}{l}\text { Wage rate ( } \$ / \text { hour in } \\
\text { current dollars) }\end{array}$} & \multicolumn{4}{|c|}{ Employment in thousands } \\
\hline & & $1980: 4$ & $1981: 1$ & $1981: 2$ & $1981: 3$ & $1980: 4$ & $1981: 1$ & $1981: 2$ & $1981: 3$ \\
\hline $\begin{array}{l}\text { Building materials, } \\
\text { hardware, etc. }\end{array}$ & 1995 & 5.68 & 5.78 & 5.88 & 5.99 & 629.9 & 634.5 & 639.1 & 643.2 \\
\hline Automotive dealers & 1975 & 6.35 & 6.47 & 6.59 & 6.70 & 1077.8 & 1085.7 & 1093.4 & 1100.5 \\
\hline $\begin{array}{l}\text { Gasoline service } \\
\text { stations }\end{array}$ & 1950 & 4.46 & 4.54 & 4.62 & 4.70 & 587.9 & 592.2 & 596.5 & 600.3 \\
\hline Apparel \& accessories & 1485 & 4.45 & 4.53 & 4.61 & 4.69 & 783.9 & 789.6 & 795.3 & 800.4 \\
\hline Other retail & 1815 & 5.46 & 5.56 & 5.66 & 5.76 & 1035.8 & 1043.4 & 1050.8 & 1057.7 \\
\hline Personal services & 1710 & 4.70 & 4.79 & 4.87 & 4.96 & 383.0 & 386.0 & 389.0 & 392.0 \\
\hline Other services & 1800 & 6.41 & 6.53 & 6.64 & 6.76 & 1303.0 & 1313.0 & 1323.0 & 1334.0 \\
\hline
\end{tabular}


Table E-5. Regulation-inducec income loss in the commercial sector iquarterly at annual rates)

\begin{tabular}{|c|c|c|c|c|c|c|c|c|}
\hline \multirow{3}{*}{$\begin{array}{l}\text { Categories of } \\
\text { business } \\
\text { establishments }\end{array}$} & \multicolumn{8}{|c|}{$\begin{array}{c}\text { Feduction in wages with reduction in hours worked } \\
\text { (billions of current } \$ \text { ! }\end{array}$} \\
\hline & \multicolumn{4}{|c|}{ GO hr week } & \multicolumn{4}{|c|}{40 hr week } \\
\hline & $1980: L$ & $1981: 1$ & $1981: 2$ & $1981: 3$ & $1980: 4$ & 1981:1 & $1981: 2$ & $1981: 3$ \\
\hline $\begin{array}{l}\text { Building materials, } \\
\text { hardware, etc. }\end{array}$ & & & & & 0.298 & 0.305 & 0.313 & 0.321 \\
\hline General merchandise & 0.803 & $C \cdot \varepsilon \approx 4$ & 0.845 & $0 . \varepsilon 65$ & 2.135 & 2.189 & 2.246 & 2.300 \\
\hline Food & 0.899 & C". 522 & 0.945 & 0.968 & 2.392 & 2.453 & 2.513 & 2.574 \\
\hline Automotive dealers & 冫 & & & & 0.876 & 0.899 & 0.921 & 0.943 \\
\hline $\begin{array}{l}\text { Gasoline service } \\
\text { stations }\end{array}$ & 0.548 & $C .5 \in 2$ & 0.576 & 0.591 & 0.791 & 0.811 & 0.832 & 0.852 \\
\hline Appare1 \& accessories & 0.217 & $C .222$ & 0.227 & 0.232 & 0.575 & 0.590 & 0.605 & 0.619 \\
\hline Furniture & & & & & 0.439 & 0.451 & 0.462 & 0.473 \\
\hline Eating \& drinking & 1.511 & 1.551 & 1.590 & 1.630 & 2.769 & 2.842 & 2.914 & 2.986 \\
\hline Drug stores & 0.245 & $C .252$ & 0.257 & 0.263 & 0.448 & 0.460 & 0.472 & 0.482 \\
\hline Other retail & & & & & 0.665 & 0.683 & 0.700 & 0.716 \\
\hline Personal services & 0.129 & C. 132 & 0.135 & 0.139 & 0.342 & 0.351 & 0.360 & 0.369 \\
\hline Other services & & & - & & 0.973 & 0.999 & 1.024 & 1.051 \\
\hline Tota1 & 4.352 & 4.465 & 4.575 & 4.688 & 12.703 & 13.033 & 13.362 & 13.686 \\
\hline
\end{tabular}




$$
Y_{i}=\left\{\sum_{j} h_{j} p_{j} w_{j}{ }^{l} j\right\}_{i},
$$

where

$$
\begin{aligned}
& i= \text { quarterly time period between } 1980: 4 \text { and } 1981: 3, i=1,4, \\
& j= \text { category of business establishment affected by regulation, } \\
& j=1,12, \\
& h_{j}= \text { normal average hours worked per employee per year, } \\
& p_{j}= \text { fractional reduction in hours worked per employee } \\
&=0.25 \times \text { fractional reduction in operating hours, } \\
& w_{j}= \text { average wage rate }(\$ / \text { hour }), \\
& l_{j}= \text { total employment, } \\
& y_{i}= \text { total income loss in the } i \text { th quarter at annual rates. } \\
& \text { The income losses under the } 60-\mathrm{hr} \text {-week operation are significantly }
\end{aligned}
$$
lower than those under the 40-hr week because of:

- Shorter proportion of normal operating hours affected (see Table E-1).

- Smaller number of establishments affected by the 60-hr-week restriction.

\section{E.1.3 Determination of energy effects}

Reduction in the operating hours of commercial establishments is assumed to save between 150,000 and $175,000 \mathrm{bb} 1$ /day of oil equivalent. The energy saved is assumed to be used in the manufacturing sector, alleviating the $600,000-b b 1 /$ day shortfall. As a consequence, the output from the sector is assumed to increase above levels in the baseline economy and is reflected by an increase in the index of production [Appendix D, Eq. (3)] as shown in Table E-6.

\section{E.1.4 Simulation results}

The results from the simulation of the economy under regulation incorporating the sales, employment income, and energy effects are shown in Tables E-7 through E-10 in comparison with the baseline economy. Section 4.3 contains a discussion of these results.

\section{Legend to Tables E-7 through E-10}

GNP72: $\quad$ gross national product in billions of 1972 \$

C72: personal consumption expenditures in billions of 1972 \$

IFIX72: gross private domestic fixed investment in billions of $1972 \$$ 
Table E-6. Energy effect of regulation

\begin{tabular}{|c|c|c|c|c|}
\hline & \multicolumn{4}{|c|}{ Time period } \\
\hline & $1980: 4$ & $1981: 1$ & 1981: 2 & $1981: 3$ \\
\hline \multicolumn{5}{|c|}{$\begin{array}{l}\text { Energy shortfall to } \\
\text { manufacturing sector in } \\
\text { baseliute ecomomy (m1llion } \\
\text { bbl/day of energy) }\end{array}$} \\
\hline \multicolumn{5}{|c|}{$\begin{array}{l}\text { Regularlon-induced illerease } \\
\text { in energy availability } \\
\text { (million bbl/day of energy) }\end{array}$} \\
\hline $\begin{array}{l}\text { 60-hr week } \\
40-\mathrm{hr} \text { week }\end{array}$ & $\begin{array}{l}+0.15 \\
+0.175\end{array}$ & $\begin{array}{l}+0.15 \\
+0.175\end{array}$ & $\begin{array}{l}+0.15 \\
+0.175\end{array}$ & $\begin{array}{l}+0.15 \\
+0.175\end{array}$ \\
\hline \multicolumn{5}{|c|}{$\begin{array}{l}\text { Energy shortfall to } \\
\text { manufacturing sector under } \\
\text { regulation (million bbl/day } \\
\text { of energy) }\end{array}$} \\
\hline $\begin{array}{l}\text { 60-hr week } \\
40-\mathrm{hr} \text { week }\end{array}$ & $\begin{array}{l}-0.45 \\
-0.425\end{array}$ & $\begin{array}{l}-0.45 \\
-0.47 .5\end{array}$ & $\begin{array}{l}-0.45 \\
-0.425\end{array}$ & $\begin{array}{l}-0.45 \\
-0.425\end{array}$ \\
\hline \multicolumn{5}{|c|}{$\begin{array}{l}\text { Index of industrial produc- } \\
\text { tion manufacturing }\end{array}$} \\
\hline Baseline economy. & 1.449 & 1.478 & 1.496 & 1.505 \\
\hline $\begin{array}{l}\text { Regulatcd economy } \\
60-\mathrm{hr} \text { week } \\
\text { 40-hr week }\end{array}$ & $\begin{array}{l}1.478 \\
1.483\end{array}$ & $\begin{array}{l}1.506 \\
1.511\end{array}$ & $\begin{array}{l}1.524 \\
1.529\end{array}$ & $\begin{array}{l}1.534 \\
1.539\end{array}$ \\
\hline
\end{tabular}


Table E-7. Measures of economic activity under regulations $60 \mathrm{hr} /$ week with no decline in sales

$$
\begin{array}{ll}
A=\text { regulated economy } & D=A-B \\
B=\text { baseline economy } & \%=(D / B) \times 100
\end{array}
$$

\begin{tabular}{|c|c|c|c|c|c|c|}
\hline & $80: 4$ & $81: 1$ & $81: 2$ & $81: 3$ & $81: 4$ & $82: 1$ \\
\hline \multicolumn{7}{|c|}{ - GNP72 } \\
\hline $\mathrm{A}$ & 1487.9 & 1504.3 & 1513.8 & 1521.8 & 1533.8 & 1542.5 \\
\hline B & 1488.0 & 1504.9 & 1514.3 & 1522.1 & 1533.8 & 1542.5 \\
\hline D. & -0.2 & -0.6 & -0.6 & -0.4 & -0.0 & -0.0 \\
\hline$\%$ & -0.0 & -0.0 & -0.0 & -0.0 & -0.0 & -0.0 \\
\hline \multicolumn{7}{|c|}{$--c 72$} \\
\hline A & 961.5 & 972.4 & 980.0 & 986.5 & 991.8 . & 997.9 \\
\hline B & 962.1 & 973.9 & 981.8 & 988.4 & 991.8 & 997.9 \\
\hline $\mathrm{D}$ & -0.6 & -1.5 & -1.8 & -1.8 & 0.0 . & 0.0 \\
\hline$\%$ & -0.1 & -0.2 & -0.2 & -0.2 & 0.0 & 0.0 \\
\hline \multicolumn{7}{|c|}{-- IFIX72 } \\
\hline A & 210.2 & 213.8 & 216.2 & 216.5 & 218.4 & 218.4 \\
\hline B & 210.3 & 213.8 & 216.1 & 216.3 & 218.4 & 218.4 \\
\hline $\mathrm{D}$ & -0.1 & 0.0 & 0.1 & 0.2 & 0.0 & 0.0 \\
\hline$\%$ & -0.0 & 0.0 & 0.0 & 0.1 & 0.0 & 0.0 \\
\hline \multicolumn{7}{|c|}{-- INVNF72CH } \\
\hline $\mathrm{A}$ & 10.4 . & 11.8 & 10.4 & 10.0 & 11.1 & 11.9 \\
\hline B & 9.8 & 11.3 & 9.9 & 9.6 & 11.1 & 11.9 \\
\hline $\mathrm{D}$ & 0.6 & 0.5 & 0.5 & 0.4 & 0.0 & 0.0 \\
\hline$\%$ & 6.1 & 4.3 & 5.4 & 4.5 & 0.0 & 0.0 \\
\hline \multicolumn{7}{|c|}{--- YD72 } \\
\hline$A$ & 1062.0 & 1068.5 & 1074.9 & 1085.6 & $1086.8^{\circ}$ & 1092.4 \\
\hline $\mathrm{B}$ & 1065.9 & 1071.7 & 1077.9 & 1088.5 & 1086.8 & 1092.4 \\
\hline $\mathrm{D}$ & -3.9 & -3.2 & -3.0 & -2.8 & 0.0 & 0.0 \\
\hline$\%$ & -0.4 & -0.3 & -0.3 & -0.3 & 0.0 & 0.0 \\
\hline \multicolumn{7}{|c|}{-- ËंH } \\
\hline $\mathrm{A}$ & 98.9 & 99.7 & 100.4 & 101.0 & 101.6 & 102.1 \\
\hline B & 98.9 & 99.7 & 100.4 & 101.0 & 101.6 & 102.1 \\
\hline $\mathrm{D}$ & -0.0 & -0.0 & -0.0 & -0.0 & 0.0 & 0.0 \\
\hline$\%$ & -0.0 & -0.0 & -0.0 & -0.0 & 0.0 & 0.0 \\
\hline \multicolumn{7}{|c|}{$---\mathrm{CPIU}$} \\
\hline A & 2.354 & 2.399 & 2.445 & 2.491 & 2.518 & 2.562 \\
\hline B & 2.354 & 2.399 & 2.445 & 2.491 & 2.518 & 2.562 \\
\hline$D$ & 0.000 & 0.000 & 0.000 & 0.000 & $0.000^{\circ}$ & 0.000 \\
\hline$\%$ & 0.0 & 0.0 & 0.0 & 0.0 & 0.0 & 0.0 \\
\hline
\end{tabular}


Table E-8. Measures of economic activity under regulations $40 \mathrm{hr} /$ week with no decline in sales
$\mathrm{A}=$ regulated economy
$D=A-B$
$\mathrm{B}=$ baseline economy
$\%=(D / B) \times 100$

\begin{tabular}{|c|c|c|c|c|c|c|}
\hline & $80: 4$ & $81: 1$ & $81: 2$ & $81: 3$ & $81: 4$ & $82: 1$ \\
\hline \multicolumn{7}{|c|}{-- GNP72 } \\
\hline A & 1487.4 & 1502.6 & 1511.2 & 1518.6 & 1533.8 & 1542.5 \\
\hline B & 1488.0 & 1504.9 & 1514.3 & 1522.1 & 1533.8 & 1542.5 \\
\hline $\mathrm{D}$ & -0.6 & -2.3 & -3.1 & -3.5 & 0.0 & 0.0 \\
\hline$\%$ & -0.0 & -0.2 & -0.2 & -0.2 & 0.0 & 0.0 \\
\hline \multicolumn{7}{|c|}{$---c 72$} \\
\hline $\mathrm{A}$ & 961.0 & 970.5 & 977.3 & 983.3 & 991.8 & 997.9 \\
\hline B & 962.1 & 973.9 & 981.8 & 988.4 & 991.8 & 997.9 \\
\hline $\mathrm{D}$ & -1.1 & -3.4 & -4.4 & -5.0 & 0.0 & 0.0 \\
\hline$\%$ & -0.1 & -0.3 & -0.5 & -0.5 & 0.0 & 0.0 \\
\hline \multicolumn{7}{|c|}{ - IFIX $T 2$} \\
\hline $\mathrm{A}$ & 210.2 & 213.6 & 215.9 & 216.1 & 218.4 & 218.4 \\
\hline B & 210.3 & 213.8 & 216.1 & 216.3 & 218.4 & 218.4 \\
\hline $\mathrm{D}$ & -0.2 & -0.2 & -0.2 & -0.3 & 0.0 & 0.0 \\
\hline$\%$ & -0.1 & -0.1 & -0.1 & -0.1 & 0.0 & 0.0 \\
\hline \multicolumn{7}{|c|}{--- INVNF72CH } \\
\hline A & 10.7 & 12.0 & 10.5 & 10.0 & 11.1 & 11.9 \\
\hline$B$ & 9.8 & 11.3 & 9.9 & 9.6 & 11.1 & 11.9 \\
\hline $\mathrm{D}$ & 0.9 & 0.7 & 0.6 & 0.4 & 0.0 & 0.0 \\
\hline$\%$ & 8.9 & 6. 3 & 6.2 & 3.9 & 0.0 & 0.0 \\
\hline \multicolumn{7}{|c|}{--- YD72 } \\
\hline $\mathrm{A}$ & 1058.2 & 1064.0 & 1069.9 & 1080.3 & 1086.8 & 1092.4 \\
\hline B & 1065.9 & 1071.7 & 1077.9 & 1088.5 & 1086.8 & 1092.4 \\
\hline $\mathrm{D}$ & -7.7 & -1.1 & -8.0 & -8.2 & 0.0 & 0.0 \\
\hline$\%$ & -0.7 & -0.7 & -0.7 & -0.8 & 0.0 & 0.0 \\
\hline \multicolumn{7}{|c|}{ 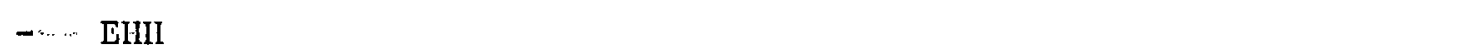 } \\
\hline $\mathrm{A}$ & 98.9 & 99.7 & 100.3 & 100.9 & 101.6 & 102.1 \\
\hline $\mathrm{B}$ & 98.9 & 99.7 & 100.4 & 101.0 & 101.6 & 102.1 \\
\hline $\mathrm{D}$ & -0.0 & -0.0 & -0.1 & -0.1 & 0.0 & 0.0 \\
\hline$\%$ & -0.0 & -0.0 & -0.1 & -0.1 & 0.0 & 0.0 \\
\hline \multicolumn{7}{|c|}{--- CPIU } \\
\hline $\mathrm{A}$ & 2.354 & 2.399 & 2.445 & 2.491 & 2.518 & 2.562 \\
\hline $\mathrm{B}$ & 2.354 & 2.399 & 2.445 & 2.491 & 2.518 & 2.562 \\
\hline $\mathrm{D}$ & 0.000 & 0.000 & -0.000 & -0.000 & 0.000 & 0.000 \\
\hline$\%$ & 0.0 & 0.0 & -0.0 & -0.0 & 0.0 & 0.0 \\
\hline
\end{tabular}


Tab1e E-9. Measures of economic activity under regulations $60 \mathrm{hr} /$ week with no decline in sales

$$
\begin{array}{ll}
A=\text { regulated economy } & D=A-B \\
B=\text { baseline economy } & \%=(D / B) \times 100
\end{array}
$$

\begin{tabular}{|c|c|c|c|c|c|c|}
\hline & $80: 4$ & $81: 1$ & $81: 2$ & $81: 3$ & $81: 4$ & $82: 1$ \\
\hline \multicolumn{7}{|c|}{--- GNP72 } \\
\hline A & 1482.6 & 1494.3 & 1504.5 & 1512.4 & 1533.8 & 1542.5 \\
\hline B & 1488.0 & 1504.9 & 1514.3 & 1522.1 & 1533.8 & 1542.5 \\
\hline $\mathrm{D}$ & -5.5 & -10.6 & -9.8 & -9.7 & 0.0 & 0.0 \\
\hline$\%$ & -0.4 & -0.7 & -0.6 & -0.6 & 0.0 & 0.0 \\
\hline \multicolumn{7}{|c|}{$--C 72$} \\
\hline A & 954.3 & 963.8 & 971.1 & 977.2 & 991.8 & 997.9 \\
\hline B & 962.1 & 973.9 & 981.8 & 988.4 & 991.8 & 997.9 \\
\hline D & -7.8 & -10.1 & -10.7 & -11.2 & 0.0 & 0.0 \\
\hline$\%$ & -0.8 & -1.0 & -1.1 & -1.1 & 0.0 & 0.0 \\
\hline \multicolumn{7}{|c|}{-- IFIX72 } \\
\hline A & 209.7 & 213.1 & 215.2 & 215.3 & 218.4 & 218.4 \\
\hline B & 210.3 & 213.8 & 216.1 & 216.3 & 218.4 & 218.4 \\
\hline D & -0.6 & -0.7 & -0.8 & -1.0 & 0.0 & 0.0 \\
\hline$\%$ & -0.3 & -0.3 & -0.4 & -0.5 & 0.0 & 0.0 \\
\hline \multicolumn{7}{|c|}{--- INVNF72CH } \\
\hline A & 12.6 & 10.5 & 10.0 & 10.1 & 11.1 & 11.9 \\
\hline B & 9.8 & 11.3 & 9.9 & 9.6 & 11.1 & 11.9 \\
\hline D & 2.8 & -0.9 & 0.1 & 0.4 & 0.0 & 0.0 \\
\hline$\%$ & 28.9 & -7.6 & 1.4 & 4.6 & 0.0 & 0.0 \\
\hline \multicolumn{7}{|c|}{$---Y D 72$} \\
\hline A & 1059.3 & 1062.8 & 1069.6 & 1080.3 & 1086.8 & 1092.4 \\
\hline B & 1065.9 & 1071.7 & $1077: 9$ & 1088.5 & 1086.8 & 1092.4 \\
\hline D & -6.6 & -8.9 & -8.3 & -8.1 & 0.0 & 0.0 \\
\hline$\%$ & -0.6 & -0.8 & -0.8 & -0.7 & 0.0 & 0.0 \\
\hline \multicolumn{7}{|c|}{---EHH } \\
\hline A & 98.9 & 99.5 & 100.1 & 100.7 & 101.6 & 102.1 \\
\hline B & 98.9 & 99.7 & 100.4 & 101.0 & 101.6 & 102.1 \\
\hline D & -0.1 & -0.2 & -0.2 & -0.3 & 0.0 & 0.0 \\
\hline$\%$ & -0.1 & -0.2 & -0.2 & -0.3 & 0.0 & 0.0 \\
\hline \multicolumn{7}{|c|}{$--C P I U$} \\
\hline A & 2.354 & 2.399 & 2.444 & 2.490 & 2.518 & 2.562 \\
\hline B & 2.354 & 2.399 & 2.445 & 2.491 & 2.518 & 2.562 \\
\hline D & -0.000 & -0.000 & -0.001 & -0.001 & 0.000 & 0.000 \\
\hline$\%$ & -0.0 & -0.0 & -0.0 & -0.1 & 0.0 & 0.0 \\
\hline
\end{tabular}


Table E-10. Measures of economic activity under regulations $40 \mathrm{hr} /$ week with no decline in sales
$A=$ regulated economy
$\mathrm{B}=$ baseline economy
$\mathrm{D}=\mathrm{A}-\mathrm{B}$
$\%=(D / B) \times 100$

\begin{tabular}{|c|c|c|c|c|c|c|}
\hline & $80: 4$ & $81: 1$ & $81: 2$ & $81: 3$ & $81: 4$ & $82: 1$ \\
\hline \multicolumn{7}{|c|}{--- GNP72 } \\
\hline A & 1471.3 & 1471.1 & 1481.5 & 1490.5 & 1533.8 & 1542.5 \\
\hline B & 1488.0 & 1504.9 & 1514.3 & 1522.1 & 1533.8 & 1542.5 \\
\hline $\mathrm{D}$ & -16.7 & -33.8 & -32.8 & -31.6 & 0.0 & 0.0 \\
\hline$\%$ & -1.1 & -2.2 & -2.2 & -2.1 & 0.0 & 0.0 \\
\hline \multicolumn{7}{|c|}{$--\mathrm{C} / 2$} \\
\hline A & 939.0 & 944.4 & 949.8 & 955.8 & 991.8 & 997.9 \\
\hline B & 962.1 & 973.9 & 981.8 & 988.4 & 991.8 & 497.9 \\
\hline$\pi$ & -23.1 & -29.4 & $-3 i . y$ & -32.6 & 0.0 & 0.0 \\
\hline \multirow[t]{2}{*}{$\%$} & -2.4 & -3.0 & -3.3 & -3.3 & 0.0 & 0.0 \\
\hline & $\operatorname{IFIX72}$ & & & & & \\
\hline$\overline{\mathrm{A}}$ & 208.6 & 211.5 & 213.0 & 212.6 & 218.4 & 218.4 \\
\hline B & 210.3 & 213.8 & 216.1 & 216.3 & 218.4 & 218.4 \\
\hline $\mathrm{D}$ & -1.7 & -2.3 & -3.1 & -3.8 & 0.0 & 0.0 \\
\hline$\%$ & -0.8 & -1.1 & -1.5 & -1.7 & 0.0 & 0.0 \\
\hline \multicolumn{7}{|c|}{$-\rightarrow$ INVNF72CH } \\
\hline A & 17.5 & 7.0 & 8.1 & 9.8 & 11.1 & 11.9 \\
\hline B & 9.8 & 11.3 & 9.9 & 9.6 & 11.1 & 11.9 \\
\hline $\mathrm{D}$ & 7.7 & -4.3 & -1.4 & 0.2 & 0.0 & 0.0 \\
\hline$\%$ & 70.2 & -38.11 & -14.7 & 2.2 & 0.0 & 0.0 \\
\hline \multicolumn{7}{|c|}{-.. YD72 } \\
\hline A & 1049.6 & 1045.6 & 1052.7 & 1064.2 & 1086.8 & 1092.4 \\
\hline B & 1065.9 & 1071.7 & 1077.9 & 1088.5 & $1086 \div 8$ & 1092.4 \\
\hline D & -16.2 & $-26,1$ & -25.3 & $=24.2$ & 0.0 & 0.0 \\
\hline$\%$ & -1.5 & -2.4 & -2.3 & -2.2 & 0.0 & 0.0 \\
\hline \multicolumn{7}{|c|}{---EHH } \\
\hline A & $9 \overline{8} .8$ & 99.2 & 99.6 & 100.0 & 101.6 & 102.1 \\
\hline B & 98.9 & 99.7 & 100.4 & 101.0 & 101.6 & 102.1 \\
\hline$D$ & -0.2 & -0.5 & -0.8 & -0.9 & 0.0 & 0.0 \\
\hline$g$ & 0.2 & -0.3 & -0.8 & -0.9 & 0.0 & 0.0 \\
\hline \multicolumn{7}{|c|}{$---C P I U$} \\
\hline A & 2.354 & 2.398 & 2.442 & 2.487 & 2.518 & 2.562 \\
\hline B & 2.354 & 2.399 & 2.445 & 2.491 & 2.518 & 2.562 \\
\hline D & -0.000 & -0.001 & -0.003 & -0.005 & 0.000 & 0.000 \\
\hline$\%$ & -0.0 & -0.0 & -0.1 & -0.2 & 0.0 & 0.0 \\
\hline
\end{tabular}


INVNF72CH: change in business inventories in billions of 1972 \$

YD72: disposable personal income in billions of 1972 \$

EHH: $\quad$ total employed in millions

CPIU: $\quad$ consumer price index - urhan $(1972=1.00)$

Note: The loss in employment relative to the baseline economy evident in all the simulation results actually reflects only a secondorder effect. In Sect. 4.3 it was indicated that the primary effects on employment induced by the regulation could not explic1tly be determined, but could only be measured through the loss of personal income. Using the results shown in Tables E-7 through E-10, an unemployment equivalent of income loss and a corresponding unemployment rate equivalent can be derived as follows:

$$
\begin{aligned}
& \begin{array}{l}
\text { regulation-induced income loss }=\Delta Y \mathrm{Y} 72=(\mathrm{YD} 72) \text { baseline } \\
(\text { YD72) } \\
\text { regulation in each quarterly period }
\end{array} \\
& \left.\begin{array}{l}
\text { average income/employed }= \\
\text { over the period 1980:4 to } 1981: 3
\end{array}\right\} \begin{array}{l}
=\frac{\text { average }(\mathrm{YD} 72) \text { baseline }}{\text { average }(\mathrm{EHH}) \text { baseline }} \\
=\mathrm{W}=\$ 10760
\end{array}
\end{aligned}
$$

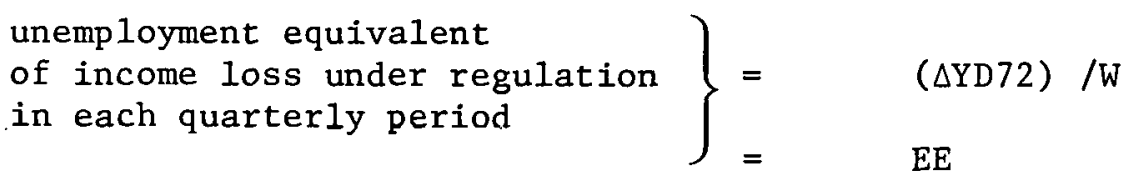

$$
\begin{aligned}
& \text { unemployment rate } \\
& \text { equivalent of income loss } \\
& \text { under regulation in each } \\
& \text { quarterly period } \\
& \}=\left(L C-E H H+E E^{\prime}\right) / L C
\end{aligned}
$$

where

$$
\begin{aligned}
E H H= & \text { total employment in the baseline case in each quarter from } \\
& 1980: 4 \text { through } 1981: 3, \\
\mathrm{LC}= & \text { total labor force available for employment in each quarter } \\
& \text { from 1980:4 through 1981:3, which is the same regardless of } \\
& \text { economic conditions. }
\end{aligned}
$$
E-12.

\section{E. 1.5 Regional impacts}

Economic impacts were analyzed for DOE regions I, IV, and VI. The states comprising these regions are shown in Table E-13. The major assumptions underlying the analysis were as follows: 
Table E-11. Unemployment equivalent of income loss at national level (thousands)

\begin{tabular}{lcccc}
\hline & \multicolumn{3}{c}{ Time period } \\
\cline { 2 - 5 } & $1980: 4$ & $1981: 1$ & $1981: 2$ & $1981: 3$ \\
\hline $\begin{array}{c}\text { 60-hr week } \\
\text { with no sales decline }\end{array}$ & 362 & 297 & 279 & 260 \\
$\begin{array}{l}\text { 40-hr week } \\
\text { with no sales decline }\end{array}$ & 716 & 716 & 743 & 762 \\
$\begin{array}{l}\text { 60-hr week } \\
\text { with sales decline }\end{array}$ & 613 & 827 & 771 & 753 \\
$\begin{array}{l}\text { 40-hr week } \\
\text { with sales decline }\end{array}$ & 1506 & 2426 & 2351 & 2249 \\
\hline
\end{tabular}

Table E-12. Unemployment rate equivalent of income loss at nationa1 lovel (pcrcent)

\begin{tabular}{lllll}
\hline & \multicolumn{3}{c}{ Time period } \\
\cline { 2 - 5 } & $1980: 4$ & $1981: 1$ & $1981: 2$ & $1981: 3$ \\
\hline $\begin{array}{l}\text { 60-hr wcck } \\
\text { with no sales decline }\end{array}$ & .7 .01 & 6.75 & 6.70 & 6.64 \\
$\begin{array}{l}\text { 40-hr week } \\
\text { with no sales decline }\end{array}$ & 7.37 & 7.14 & 7.12 & 7.10 \\
$\begin{array}{l}\text { 60-hr week } \\
\text { with sàies decline }\end{array}$ & 1.28 & 7.25 & 7.15 & 7.09 \\
$\begin{array}{l}\text { 40-hr week } \\
\text { with sales decline }\end{array}$ & 8.12 & 8.75 & 8.62 & 8.48 \\
\hline
\end{tabular}

NOTE: The labor force in each of the four quarters was 106.0, 106.6, 107.3, 107.9 millions respectively. The corresponding unemployment rates in the baseline economy were $6.70,6.47,6.43$, and $6.39 \%$ respectively. 
Table E-13. DOE regions considered for analysis

\begin{tabular}{ll}
\hline & States within region \\
\hline Region I & Connecticut \\
& Massachusetts \\
& Maine \\
& New Hampshire \\
& Rhode Island \\
& Vermont \\
Region IV & Alabama \\
& Florida \\
& Kentucky \\
& Gecrgia \\
& Mississippi \\
& North Carolina \\
& South Carolina \\
& Tennessee \\
& Arkansas \\
Region VI & Louisiana \\
& New Mexico \\
& Oklahoma \\
& Texas \\
\hline
\end{tabular}

- Regulations would be implemented uniformly across the regions, and responses of firms and consumers in each region would on the average be similar.

- Regional impacts within the commercial sector will be proportional to the extent of the sector's activity measured by its share of sales, employment, and wages relative to national levels.

- Multiplier effects of sector-specific income and employment losses determined nationally are applicable regionally.

Regional shares of selected economic and demographic variables are shown in Tables E-14 and E-15 for the period 1972 through 1980-81. Projections to 1980-81 were made for the baseline case, using growth rates for the variables between 1972 and 1977. Of the three regions considered, region I shows a slight decline in its shares of population, labor force, employment, and income, while regions IV and VI show a modest increase.

The regional patterns of commercial sector activity (in retail trade and selected service categories) relative to national aggregate levels are shown in Table E-16 for 1972. A comparison of data in Table E-16 (which is commercial-sector-specific by region) with corresponding data in Table $\mathrm{E}-15$ (which is an aggregation over all 
Table E-14. Selected national and regional economic and demographic variables ${ }^{\alpha}$

(1972-1981)

\begin{tabular}{|c|c|c|c|c|}
\hline \multirow[b]{2}{*}{ Region } & \multicolumn{4}{|c|}{ Variables } \\
\hline & $\begin{array}{l}\text { Population } \\
\text { (thousands) }\end{array}$ & $\begin{array}{l}\text { Labor force } \\
\text { (thousands) }\end{array}$ & $\begin{array}{l}\text { Civilian } \\
\text { employment } \\
\text { (thousands) }\end{array}$ & $\begin{array}{l}\text { Personal income } \\
\text { (billions of } \\
\text { current \$) }\end{array}$ \\
\hline \multicolumn{5}{|l|}{ U.S. } \\
\hline 1972 & 207,598 & 86,500 & 81,700 & 932.4 \\
\hline 1977 & 216,332 & 97,400 & 90,500 & 1518.4 \\
\hline $\begin{array}{l}\text { 1980-81 } \\
\text { (projccted) }\end{array}$ & 223,583 & 107,100 & 98,218 & 2242.9 \\
\hline \multicolumn{5}{|l|}{ Region I } \\
\hline 1972 & 12,015 & $.5,253$ & 4,888 & 57.5 \\
\hline 1977 & 12,244 & 5,828 & $3,3 / 4$ & 87.9 \\
\hline $\begin{array}{l}1980-81 \\
\text { (projected) }\end{array}$ & 12,430 & 6,333 & 5,807 & 123.4 \\
\hline \multicolumn{5}{|l|}{ Region IV } \\
\hline 1972 & 33,270 & 13,476 & 12,891 & 122.4 \\
\hline 1977 & 35,737 & 15,591 & 14,523 & 214.1 \\
\hline $\begin{array}{l}1980-81 \\
\text { (projected) }\end{array}$ & 37,842 & 17,520 & 15,976 & 334.9 \\
\hline \multicolumn{5}{|l|}{ Reyiul1 VI } \\
\hline 1972 & 21,027 & 8,041 & 7,615 & 80.7 \\
\hline 1977 & 22,896 & 9,995 & 9, 亿6 & 147.2 \\
\hline $\begin{array}{l}1980-81 \\
\text { (projected) }\end{array}$ & 24,510 & 11,895 & 11,159 & 238.1 \\
\hline
\end{tabular}

sectors in each region) iridicates that regional shares of wages and employment in the commercial sector parallel those of personal income and employment for the respective regions. It is reasonable to assume that regional shares of commercial sector wages and employment over the forecast period (1980-81) would move in tandem with those of income and employment for the respective regions.

Regional shares of commercial sector sales were projected for the 1980-81 period, using best available data on growth rates between 1972 and 1977.2 As previously described (Sect. 4.3), regulation-induced losses in sales were considered to occur only in a few establishments within the retail trade and services categories (see Table E-3). The regional shares of sales in 1972 for these few establishments were found to be almost identical to those of all establishments taken together. It is reasonable to assume that this pattern would prevail in 1980-81. 
Table E-15. Selected regional economic and demographic variables relative to national ${ }^{a}$

\begin{tabular}{|c|c|c|c|c|c|}
\hline & \multicolumn{5}{|c|}{ Variables } \\
\hline & Population & $\begin{array}{l}\text { Labor } \\
\text { force }\end{array}$ & Employment & $\begin{array}{l}\text { Personal } \\
\text { income }\end{array}$ & $\begin{array}{l}\text { Personal income } \\
\text { per employed }\end{array}$ \\
\hline \multicolumn{6}{|l|}{ Region I } \\
\hline 1972 & 0.058 & 0.061 & 0.060 & 0.062 & 1.031 \\
\hline 1977 & 0.057 & 0.060 & 0.059 & 0.058 & 0.974 \\
\hline $\begin{array}{l}1980-81 \\
\text { (projected) }\end{array}$ & 0.056 & 0.059 & 0.059 & 0.055 & 0.931 \\
\hline \multicolumn{6}{|l|}{ Region IV } \\
\hline 1972 & 0.160 & 0.156 & 0.158 & 0.131 & 0.832 \\
\hline 1977 & 0.165 & 0.160 & 0.160 & 0.141 & 0.879 \\
\hline $\begin{array}{l}1980-81 \\
\text { (projected) }\end{array}$ & 0.169 & 0.164 & 0.163 & 0.149 & 0.918 \\
\hline \multicolumn{6}{|l|}{ Region VI } \\
\hline 1972 & 0.101 & 0.093 & 0.093 & 0.087 & 0.929 \\
\hline . $\quad 1977$ & 0.106 & 0.103 & 0.104 & 0.097 & 0.932 \\
\hline $\begin{array}{l}1980-81 \\
\text { (projected) }\end{array}$ & 0.110 & 0.111 & 0.114 & 0.106 & 0.934 \\
\hline
\end{tabular}

Table E-16. Regional shares of commercial sector activity in retail trade and selected services relative to nationala (1972)

\begin{tabular}{llll}
\hline & \multicolumn{3}{c}{ Variables } \\
\cline { 2 - 4 } Region & $\begin{array}{c}\text { Empluyment } \\
\text { (thousands) }\end{array}$ & $\begin{array}{c}\text { Wages } \\
\text { (billions of current \$) }\end{array}$ & (billions of current \$) \\
\hline U.S. & 16,516 & 88.8 & 582 \\
Region I & 1,014 & 5.34 & 33.9 \\
& $(6.1 \%)$ & $(6 \%)$ & $(5.8 \%)$ \\
Region IV & 2,427 & 11.9 & 85.0 \\
& $(14.7 \%)$ & $(13.4 \%)$ & $(14.6 \%)$ \\
Region VI & 1,592 & 7.7 & 54.3 \\
& $(9.6 \%)$ & $(8.7 \%)$ & $(9.3 \%)$ \\
\hline
\end{tabular}
parentheser. 
A summary of commercial sector activity at the regional level projected for 1980-81 is presented in Table E-17.

Regulation-induced losses in wages and sales in the commercial sector determined previously at the national level in 1980-81 (Tables E-3 and E-4) were assumed to be distributed regionally in proportion to their regional shares in the baseline case (shown in Table E-17). The magnitude of these regional losses in relation to those nationally are given in Table 4-14 for both the 60- and 40-hr cases. They represent two key primary regional effects of the regulation on the commercial sector.

As described previously (Sect. 4.2), direct employment effects of regulation are not easily determined. However, an overall regional unemployment equivalent of income loss (both primary losses within the commercial sector and induced secondary losses elsewhere in the economy) can be compuled.

Primary and secondary losses in disposable income determined nationally in 1980-81 (see Tables E-7 through E-10) were assumed Lo be distributed regionally in proportion to the regional shares of income shown in Table E-15. The magnitudes of these regional income losses are presented in Table 4-15 for both the 60- and 40-hr cases, considered with and without the impacts of losses in sales in the commercial sector.

The unemployment and unemployment rate equivalents of the regional income losses were computed following the procedure shown in the preceeding section. In this computation, regional values for the labor force, total employed, and income per employed in 1980-81 were determined based on their respective regional proportions shown in Table E-15 (e.g., the national labor force of 107 million in 1980-81 is distributed regionally as follows: $5.9 \%$ in region $I, 16.4 \%$ in region $I V$, and $11.1 \%$ in region VI).

Table E-17. Regional shares of commercial sector activity in retail trade and selected services relative to nationala (baseline case 1980-81)

\begin{tabular}{lccc}
\hline & \multicolumn{3}{c}{ Variables } \\
\cline { 2 - 4 } & Employment & Wages & Sales \\
\hline Region I & 0.059 & 0.055 & 0.051 \\
Region IV & 0.153 & 0.149 & 0.159 \\
Region VI & 0.114 & 0.106 & 0.113 \\
\hline
\end{tabular}

$a_{\text {The national value for the variables shown are }}$ 18 million for employment, $\$ 214$ billion for wages, and $\$ 1240$ billion for sales. 
Regulation-induced increases in the total number of unemployed persons and the resultant unemployment rates at the regional level are presented in Table 4-16. 
Appendix $\mathrm{F}$

DETERMINATION OF BASELINE CASE FOR ENVIRONMENTAL ANALYSIS

\section{F.1 Baseline environment}

The national average emission levels expected from a 1.6-million bbl/day shortfall in petroleum supplies are as follows:

Pollutant
Particulates
Sulfur oxides $\left(\mathrm{SO}_{\mathrm{x}}\right)$
Nitrogen oxides $\left(\mathrm{NO}_{\mathrm{x}}\right)$
Hydrocarbons ( $\mathrm{HC})$
Carbon monoxide (CO)

Level of emissions

$\left(10^{3}\right.$ tons)

$$
\begin{aligned}
& 11,846 \\
& 26,786 \\
& 17,183 \\
& 11,690 \\
& 54,498
\end{aligned}
$$

The levels shown above were derived from ref. 1, wherein a 3-million bbl/day shortfall was assumed, and changes in national average emissions [using Strategic Enviromental Assessment System (SEAS) data] were determined relative to a business-as-usual economy with no shortfall. Emission levels described in ref. 1 were interpolated in this study to reflect the effects of a 1.6-million bbl/day shortfall.

The baseline case pertinent to this study includes the imposition of restrictions on the temperature levels of selected private and public buildings, prior to restricting the hours of operation in the commercial sector. It was assumed in the building temperature restriction measure that savings in utility fuel use resulting from reduced electricity demand would all be essentially in petroleum fuels and to some extent in natural gas, with the use of other fuels (coal, nuclear) remaining unchanged. As a consequence a disproportionately large amount of oil is conserved in the utility sector. This assumption seems reasonable, since this measure is expected to be the first to be implemented during a perroleum shortfall situation. Later measures implemented such as the reduction in commercial operating hours considered in this study are, however, assumed to reflect a proportional savings among all utility fuels with no further bias toward petroleum. In order to reflect the environmental impacts from the imposition of the temperature restriction measure, the emissions levels shown above were modified as follows:

The direct and indirect savings in petroleum fuels and natural gas from building temperature restrictions (determined in ref. 1) were assumed in this study to be used in the manufacturing sector (see Table F-1). Using the SEAS data and the methodology stated in Sect. 4.4, net changes in the level of the criteria pollutants from the shifts in fuel use were obtained as shown in Table F-2. By combining the net 
changes in emissions from Table F-2 with the national average emission levels presented earlier, the baseline environment was characterized as shown below:

\section{Baseline envi.ronment}

(national level)

Pollutant

Particulates

Sulfur oxides $\left(\mathrm{SO}_{\mathrm{x}}\right)$

Nitrogen oxides $\left(\mathrm{NO}_{\mathrm{x}}\right)$

Hÿdrocararbons (HC)

Carbon monoxide (CO)
Level of emissions (10 $10^{3}$ tons)

$$
11,866
$$$$
26,756
$$

17,241

11,691

54,500

Regional baseline emission levels were determined from national levels based on distribution data given in ref. 1 (exhibit 3.2). These levels are shown in Table F-3.

The baseline environment represents the state of the environment from which changes arising from regulation on operating hours will be measured.

\section{F.1.1 Fuel mix considerations}

In the building temperature restriction measure, the mix of residual and distillate fuels shifted to the manufacturing sector was derived by a series of calculations. In the commercial sector, it was assumed that half of the petroleum fuels burned were residual fuels and half were distillate fuels. In the utility sector, a 90/10 distribution was assumed. Therefore, of $247 \times 10^{12} \mathrm{Btu}$ of petroleum fuels shifted from the commercial to the manufacturing sector, $123.5 \times 10^{12} \mathrm{Btu}$ was residual and $123.5 \times 10^{12}$ Btu was distillate. Similarly, of a total of $549 \times 10^{12}$ Btu shifted from the utilities sector, $494.0 \times 10^{12} \mathrm{Btu}$ was residual fuel and $55.0 \times 10^{12} \mathrm{Btu}$ was distillate fuel. From these calculations, the distribution of residual and distillate fuels shifted to the manufacturing sector was determined to be $78 \%$ residual $\left(617.5 \times 10^{12} \mathrm{Btu}\right)$ and $22 \%$ distillate $\left(178.5 \times 10^{12} \mathrm{Btu}\right)$. This distribution is very similar to that normally existing in the sector ( $72 \%$ residual and $28 \%$ distillate in 1976 as derived from data in ref. 3): 
Table F-1. Shifts in petroleum fuels and natural gas from the commercial and utilities sectors to the manufacturing sector under regulation restricting building temperatures ${ }^{a}$

$$
\left(10^{12} \mathrm{Btu}\right)
$$

\begin{tabular}{cccc}
\hline Fuel & $\begin{array}{c}\text { From commercial } \\
\text { sector }\end{array}$ & $+\begin{array}{c}\text { From utilities } \\
\text { sector }\end{array}$ & $=\begin{array}{c}\text { To manufacturing } \\
\text { sector }\end{array}$ \\
\hline Petroleum fuels & 247 & 549 & 796 \\
Natural gas & 270 & 177 & 447 \\
\hline
\end{tabular}

$a_{\text {See ref. } 1 .}$

Table F-2. Emission changes as a result of building temperature restriction

\begin{tabular}{lc}
\hline \multicolumn{1}{c}{ Pollutant } & $\begin{array}{c}\text { Change in emissions } \\
(\%)\end{array}$ \\
\hline Particulates & +0.17 \\
$\mathrm{SO}_{\mathrm{x}}$ & -0.11 \\
$\mathrm{NO}_{\mathrm{x}}$ & +0.34 \\
Hydrocarbons & +0.01 \\
Carbon monoxide & Negligible \\
\hline \multicolumn{2}{c}{$\alpha_{\text {From levels shown at beginning of }}$}
\end{tabular}

Table F-3. Emissions data for the U.S. and selected regions $\left(10^{3}\right.$ tons) (baseline case)

\begin{tabular}{lrrrrr}
\hline & \multicolumn{5}{c}{ Emissions } \\
\cline { 2 - 6 } Region & Particulates & $\begin{array}{c}\text { Sulfur } \\
\text { oxides }\end{array}$ & $\begin{array}{c}\text { Nitrogen } \\
\text { oxides }\end{array}$ & Hydrocarbons & $\begin{array}{c}\text { Carbon } \\
\text { monoxide }\end{array}$ \\
\hline U.S. & 11,866 & 26,756 & 17,241 & 11,691 & 54,500 \\
Region I & 227 & 608 & 672 & 557 & 2,360 \\
Region IV & 2,451 & 5,309 & 3,099 & 1,818 & 8,714 \\
Region VI. & $1,511$. & 1,930 & 2,428 & 1,692 & 7,583 \\
\hline
\end{tabular}




$$
\mathrm{F}-4
$$

Building temperature restriction measure

\begin{tabular}{|c|c|c|c|c|}
\hline Sector & $\begin{array}{l}\text { Petroleum } \\
\text { fuels } \\
\text { shifted }\end{array}$ & $\begin{array}{l}\text { Distribution of } \\
\text { residual and } \\
\text { distillate fuels }\end{array}$ & $\begin{array}{l}\text { Quantity of } \\
\text { residual } \\
\text { fuels }\end{array}$ & $\begin{array}{l}\text { Quantity } \\
\text { of distillate } \\
\text { fuels }\end{array}$ \\
\hline Commercial & $247 \times 10^{12} \mathrm{Btu}$ & $50 / 50$ & $123.5 \times 10^{12} \mathrm{Btu}$ & $123.5 \times 10^{12} \mathrm{Btu}$ \\
\hline Utility & $549 \times 10^{12} \mathrm{Btu}$ & $90 / 10$ & $494.0 \times 10^{12} \mathrm{Btu}$ & $55.0 \times 10^{12} \mathrm{Btu}$ \\
\hline $\begin{array}{l}\text { Manufactur- } \\
\quad \text { ing }\end{array}$ & $796 \times 10^{12} \mathrm{Btu}$ & $78 / 22$ & $617.5 \times 10^{12} \mathrm{Btu}$ & $178.5 \times 10^{12} \mathrm{Btu}$ \\
\hline
\end{tabular}

The procedure described above was used to determine the mix of residual and distillate fuels shifted to the manufacturing sector under regulation restricting commercial sector operating hours. The results are shown below:

\begin{tabular}{|c|c|c|c|c|}
\hline Sector & $\begin{array}{l}\text { Petroleum } \\
\text { fuels } \\
\text { shifted }\end{array}$ & $\begin{array}{l}\text { Distribution of } \\
\text { residual and } \\
\text { distillate fuels }\end{array}$ & $\begin{array}{l}\text { Quantity of } \\
\text { residila1. } \\
\text { fuels }\end{array}$ & $\begin{array}{l}\text { Quantity } \\
\text { of distillate } \\
\text { fuels }\end{array}$ \\
\hline & & 60-hr case & & \\
\hline Commercial & 102 & $50 / 50$ & $51.0 \times 10^{12} \mathrm{Btu}$ & $51.0 \times 10^{12} \mathrm{Btu}$ \\
\hline Utility & 48 & $90 / 10$ & $43.0 \times 10^{12} \mathrm{Btu}$ & $5.0 \times 10^{12} \mathrm{Btu}$ \\
\hline \multirow{2}{*}{$\begin{array}{l}\text { Manufactur- } \\
\quad \text { ing }\end{array}$} & 150 & $63 / 37$ & $94.0 \times 10^{12} \mathrm{Btu}$ & $56.0 \times 10^{12} \mathrm{Btu}$ \\
\hline & & 40-hr case & & \\
\hline Commerciä1 & 121 & $50 / 50$ & $60.5 \times 10^{12} \mathrm{Btu}$ & $60.5 \times 10^{12} \mathrm{Btu}$ \\
\hline Utility & 57 & $90 / 10$ & $51.3 \times 10^{12}$ Btu & $5.7 \times 10^{12} \mathrm{Btu}$ \\
\hline $\begin{array}{l}\text { Manufactu- } \\
\quad \text { ing }\end{array}$ & 178 & $63 / 37$ & $111.8 \times 10^{12} \mathrm{Btu}$ & $66.2 \times 10^{12} \mathrm{Btu}$ \\
\hline
\end{tabular}

In the context of this study, the $63 / 37$ distribution of residual and distillate fuels use shown above in the manufacturing sector was not considered to be significantly different from that shown under the temperature restriction measure. Consequently, no adjustments to the sector-specific emission factors with petroleum fuels were made. Fuel mix considerations were not addressed at the regional level because detailed data were not available. 


$$
\text { F-5 }
$$

F.1.2 Fuel allocations to the manufacturing sector national and regional

Consumption of petroleum fuels in the manufacturing sector in 1976 is shown in Table F-4 based on data from ref. 3. The regional distribution pattern shown in Table F-4 was assumed to prevail over the 1980-81 time period. Using this pattern, the regulation-induced petroleum and natural gas savings estimated nationally in the commercial sector were allocated to manufacturing sectors in the respective regions. On this basis, region IV with a substantial level of petroleum consumption in the manufacturing sector would receive almost $25 \%$ of the total national fuel savings in the commerclal sector.

Table F-4. National and regional consumption of petroleum fuels in the manufacturing sector - 1976 $\left(10^{12} \mathrm{Btu}\right)$

\begin{tabular}{lc}
\hline Region & Petroleum fuels consumption \\
\hline U.S. & 1990 \\
Region I & 208 \\
& $(10.4 \%)$ \\
Region IV & 473 \\
Region VI & $(23.8 \%)$ \\
& 126 \\
\hline
\end{tabular}

Note: Data.from ref. 3. Percent of national consumption in parentheses. 
1. Standby Conservation Plan No. 2 - Emergency Building Temperature Restrictions, Econcric Regulatory Administration, U.S. Department of Energy, Doc. No. DOE/ERA - 0047, February 1979.

2. 1978 Statistical Abstract of the United States, 99th Annual Edition, September 1978.

3. 1976 Annual Survey of Manufacturers - Fuels and Electric Energy Conserved, U.S. Department of Commerce, Doc. No. M76(AS)-4.2, May 1978.

4. 1976 Annual Survey of Manufacturers - Gererul Slulicilins for Induatry Groups and Irdustries, U.S. Department of Commerce, Dor. No. M76(AS)-1, December 1977.

5. Employment and Earnings - December 1977, U.S. Department of Labor, Bureau of Labor Statistics, Vol. 24, No. 12, Décember 1977.

6. The Retail Industry and the Energy l'risis: I'he Economile Effecl of Shortened Store Hours, National Retail Merchants Association Report, undated.

7. Williams, G. L, Vice-President, Operations Division, National Relail Merchants Association, personal communiration and unpublished reports of NRMA.

8. A Study of the Impact of Reduced Retail Store Operating Hours on sales, Employment, Economic Concentration, and Energy Consumption, Energy Resources Co., NTIS Doc. No. PB-24357y, October 1974, p. 5-17.

9. State Profile of Employment and Unemployment, 1977, U.S. Department of Labor, Bureau of Labor Statistics, October 1977.

10. 1975 Statistical Abstract of the United States, 96th Annual Ed1r1on, July 1975.

11. 1973 Statistical Abstract of the Uriled States, 94th Annual Edition, July 1973.

12. Cownty and City Data Book: 1977 - A Statistical Abstract Supplement, U.S. Department of Commerce, Bureau of the Census, May 1978. 


\section{Appendix G \\ LEGAL ISSUES ASSOCIATED WITH IMPLEMENTATION \\ OF THE EMERGENCY MEASURE}

This section identifies some of the issues which may arise if a restriction of hours of operation of commercial establishments is imposed. Due to time constraints, there has been no verification of these potential problems. Thus, nothing in this section is to be understood as a complete statement of the law. Furthermore, nothing stated herein is an official legal opinion of Oak Ridge National Laboratory.

I. Authority for, the regulation

A. Congressional authority

Congress has the authority to require closings of private businesses pursuant to the commerce clause (U. ‥ CONST. art. I, sec. 8, cl. 3).

B. Dèlegation of authority

Section 202 of the Energy Policy and Conservation Act [42 U.S.C. sec. 626 (1976)] requires the president to prescribe "energy conservation contingency plans," which impose "reasonable restrictions on the public and private use of energy."

1. It would appear that this delegation of authority is constitutional, based on Supreme Court decisions, since Panama Refining Co. v. Ryan, 293 U.S. 388 (1935), and Schecter Poultry Corp. v. U.S., 295 U.S. 495 (1935), and the fact that emergency powers were delegated.

2. Delegation of similar types of authority by state legislatures to governors pursuant to the federal measures may encounter state constitutional problems. K. DAVIS, ADMINISTRATIVE LAW TREATISE 204 (2d ed. 1978).

II. Implementation

A. Enforcement

1. Search warrants. Search warrants may be required for inspection of premises. Marshall v. Barlow's Ine. 429 U.S. 1347 (1977). 
This may present administrative problems, especially since it is estimated that businesses will increase their demands for search warrants prior to allowing inspectors to enter. The Wall Street Joumal, January 22, 1979, at 1 , col. 6 .

2. Equal protection. Study of the use of this conservation measure by North Carolina indicated the potential equal protection problems pursuant to the fourteenth amendment (…‥ ㅇNST.). Exemptions from a mandatory curtailment of hours regulation will be necessary. Any difference in treatment must stand on a "rational basis" to survive constitutional challenge.

R. Di1e procisss

1. There appears to be no valid due process claim as a result of a closing law. This is especially true in the case of an emergency measure. The closest type of case deals with Sunday and holiday closing laws, which have not been struck down on due process grounds. Herkimer Corp. v. Vizlage of Herkimer, 330 N.Y.S. 2d 747 (App. Div. 1972). Nebbia v. New York, 291 U.S. 502 (1934) stated that due process only requires "that the law shall not be unreasonable, arbitrary, or capricious, and that the means selected shall have a real and substantial relation to the object sought to be attained," 291 U.S. at 511.

C. Labor

1. Labor contracts vary according to region, industry, union, etc. All that can be said at this point is that emergency closing is a matter for which employers and employees should prepare. Layoff procedures are often specified in the labor contracts. However, analogy could be made to procedures employed by parties to TVA's interruptible customer contracts.

III. Post-implementation problems

A. If a particular state is successful, will its energy resources be transferred to less fortunate areas pursuant to legislation such as the Emergency Petroleum Allocation Act [sec. 15, U.S.C. Secs. 751 to 756 (1976)].

1. Attempts by states to keep their resources within state boundaries will most likely be unconstitutional, Hood $v$. DuMond, 336 U.S. 525 (1949); Pennsyzvania v. West Virginia, 262 U.S. 553 (1923); West v. Kansas Natural Gas Co., 221 U.S. 229 (1911), especially if Congress has addressed the issue, Hinds v. Davidowitz, 312 U.S. 52 (1941). 
B. If some areas are successful in reducing electricity consumption, rates may have to rise, calling public commission procedures into play. A statute may grant the commission authority to modify rates in an emergency situation, Baker v. Pennsylvania

- Public Utility Commission, 332 A. 2d 735 (Pa. Commw. Ct. 1974).

IV. Conclusion

Though there may be some problems in implementing this conservation measure, at this general level of analysis, none appear to be insurmountable. On the other hand, the states may be more receptive in energy conservation contingency plans which allow them greater flexibility in achieving emergency conservation goals. 
Appendix $\mathrm{H}$

AUTHORITIES NEED, RATIONALE, OPERATION

\section{H. 1 Conditions of exercise}

(a) This plan shall not become effective unless the president:

(1) has found that putting the plan into effect is required by a severe energy supply interruption or in order to fulfill obligations of the United States under the international energy program;

(2) has transmitted such finding to the Congress with a statement of the effective date and manner for exercise of the plan.

(b) This plan may remain in effect for no more than nine months, and may be earlier rescinded by the president.

\section{H.1.1 Definitions}

As used in this plan:

(a) "Commercial sector" includes wholesale trade, retail, finance, insurance, real estate, business and repair services, amusement and recreation services, and public administration. It specifically excludes hotels and motels, health care facilities, and transportation.

(b) "Covered building" means every building within the commercial sector as defined above.

(c) "DOE" means Department of Energy.

(d) "Economics" is the study of how people choose, with or without the use of money, to employ scarce productive resources to produce commodities and distribute them for consumption among various groups (after Paul A. Samuelson).

(e) "Energy" means the capacity to perform work, such as providing heat to buildings, running motors, and providing light. Energy may be measured in British thermal units (Btu). One Btu is the energy required to increase the temperature of one pound of water $1^{\circ} \mathrm{F}$. Energy in the amount of $10^{15} \mathrm{Btu}$, or one quadrillion $B t u$, is one quad (Q). One million barrels/day of crude oil would supply $2.2 \mathrm{Q}$ of energy in one year. 
(f) "Environment" means the combination of external physical conditions that affect the growth and development of organisms, with special emphasis on air and water quality.

(g) "ERA" means Economic Regulatory Administration.

(h) "Fuel" means materials such as coal, oil, or natural gas burned to produce heat and/or electricity or fissionable material used in a nuclear reactor to produce heat and electricity.

(i) "Hours of operation" means the hours per week the commercial building is open to the public to transact its normal business.

(j) "In charge of" means to have care of, or be entrusted with the management of (a covered building).

(k) "Operator" means any person who is in charge of the hcating, cooling, or hot water of a covered bullding.

(1) "Owner" means the person in whom is vested legal title.

(m) "Secretary" means the secretary of energy or his delegate.

\section{H.1.2 Heating and cooling}

(a) The owner of a covered building shall, with respect to such covered building:

(1) maintain the thermostat or thermostats controlling the temperacures of areas belug lieated, at no higher than $65^{\circ} \mathrm{F}$ during houro opectflud fut business and $\mathrm{nn}$ higher than $55^{\circ} \mathrm{F}$ during closed hours, or any other levels which the secretary determines are reasonable and necessary to reduce energy consumption;

(2) maintain the thermostat or thermostats controlling the temperatures of areas being cooled at no lower than $80^{\circ} \mathrm{F}$ during hours specified for business and all cooling turned off during closed hours, or any other levels which the secretary determines are reasonable and necessily lu reduce energy consumption;

(3) maintain a11. thermostats controlling the temperatures of areas being heated or cooled within reasonable tolerances of accuracy. 
(b) Notwithstanding paragraphs (1) and (2) of subsection (a) of this section, where a "manufacturer's warranty" requires specific temperature levels for the operation of special equipment, such specified levels are permissible, and if a range is specified, that level within the range is permissible which is consistent with maximum energy savings.

(c) Notwithstanding paragraphs (1) and (2) of subsection (a) of this section, where special environmental conditions are required to protect animal or plant life or materials, such conditions may be maintained.

\section{H.1.3 Reports and record keeping}

(a) The owner of a covered building sha11, for such covered building, complete and post in a prominent location of the covered building, within 30 days after the effective date of this plan, and shall update at such times as the secretary may require, a building owners certificate certifying compliance with the requirements of this plan, in accordance with forms and instructions provided by the secretary.

(b) In addition to the building owners certificate, the owner of a covered building shall keep such records and in such form, and shall submit such reports and other information, as the secretary may require.

\section{H. 1.4 Operators}

Notwithstanding any other provisions of this plan to the contrary, where the owner of a covered building is not the operator of such covered building, the operator and the owner shall be jointly and severally liable for the execution of owner responsibilities under this plan.

\section{H.1.5 Customer lists}

Any public utility or fuel distributor shall make available to the secretary, upon request, information deemed necessary by the secretary to administer and enforce the plan.

\section{H.1.6 Relation to state law}

(a) This plan shall apply in every state (including the District of Columbia, Puerto Rico, or any territory or possession of the United States) and political subdivision thereof and shall preempt any law of any state or political subdivision thereof to the extent that such law is inconsistent with this plan or any rule, regulation, or order promulgated pursuant to this plan. 
(b) Notwithstanding the provisions of subsection (a) of this section, the president or his delegate, may, on his own initiative in response to a request for exemption, exempt a state or political subdivision thereof from this plan and any rule, regulation, or order promulgated pursuant to this plan, in whole or in part, during a period for which (1) the president or his delegate determines a comparable program of such state or political subdivision is in effect, or (2) the president or his delegate finds special circumstances exist in such státe or political subdivision.

(c) A state which seeks an exemption for itself or a political subdiviaion thereof on the ground that a comparable program is in etfect shall submit to the secrecary a request for exemption which shall include (1) a full description of the comparable program, (2) the amount of energy which such program will conserve, (3) the period of time during which such program will be in effect, and (4) such other information as the secretary may require, and the secretary shall review the request and make a recommendation thereon to the president or his delegate.

(d) A state which seeks an exemption for itself, or a political subdivision thereof, on the ground that special circumstances exist shall submit to the secretary a request for exemption which shall include (1) a full description of the special circumstances, (2) a detailed explanation of why implementation of this plan, in whole or in part, is not practicable, (3) an estimation of the period of time in which the special circumstances will exist, (4) any alternative energy conservation measures which may be practicable and their expected savings, and (5) such other information as the secretary may require, and the secretary shall revicw the request and make a recommendation thereon to the president or his delegate.

(e) For purposes of this section, "comparable program" means a program which deals with the same subject matter as. this plun, which is mandatory, and which conserves at least as much energy in the state or political subdivision thereof as this plan would be expected to conserve in such state or political suhdivision.

\section{H.1.7 Administrative procedures}

(a) The secretary is authorized and directed to implement, administer (including determination of exceptions), monitor, and enforce this plan, and to promulgate such additional rules, regulations, or orders as are necessary or appropriate. 
(b) Section 523 of the Energy Policy and Conservation Act of 1975 (42 U..S.C. 6393) shall apply to any rule, regulation, or order having the applicability and effect of a rule as defined in Section 441 (4) of Title 5, United States Code, issued under this plan.

(c) The secretary may delegate all or any portion of the authority granted to him under this plan to such officers, departments, or agencies of the United States, or to the govenor of any state, as he deems appropriate.

\section{H.1.8 Public information}

The secretary may collect and disseminate such information in accordance with current law and policy, as he deems appropriate regarding the operation and goals of, and responsibilities under, this plan.

\section{H.1.9 Penalties}

Any person who fails to comply with any provision prescribed in, or pursuant to, this plan shall be subject to the applicable penalties set forth in Sections 524 and 525 of the Energy Policy and Conservation Act (42 U.S.C. 6394, 6395).

\section{H.1.10 Report}

The secretary shall report to Congress and the president, within 60 days after the termination of this plan, on the operation of the plan. Such report shall include an estimate of the energy conservation achieved and may include any recommendations deemed appropriate hy the secretary.

\section{H.2 Statement of the need for rationale and operation of the plan}

\section{H.2.1 Need for the plan}

The Restricted Hours of Operation for Commercial Buildings Plan is intended for implementation in the event of a severe energy supply interruption or in order to fulfill obligations of the United States under the International Energy Program (IEP). An interruption of a significant portion of the United States' foreign oil supply could produce an energy crisis of even greater severity than that produced by the 1973-74 oil embargo. At the time of that embargo, the nation's inability to import sufficient quantities of oil resulted in an estimated $\$ 10$ to $\$ 20$ billion decline in gross national product and considerable economic and social disruption. Imports now exceed eight million barrels per day, and although domestic production increased from 1977-78, 
it is still lower than in 1973. At the present time the United States imports, at an annual rate, almost $50 \%$ of domestic petroleum requirements, compared with less than 35\% just prior to the 1973-74 embargo. Thus, the nation is in some respects more vulnerable to an interruption in foreign oil supply today than just six years ago.

Under the IEP, in an embargo or shortage situation in which only one or few member nations lose more than $7 \%$ of normal petroleum requirements, the targeted country or countries must absorb any shortfall up to $7 \%$. The other member nations would share the remaining shortfall among themselves. In the event of a widespread shortage, in which all oilconsuming countries sustain a reduction of not more than $7 \%$ of the normal petroleum consumption rate; each participating country must absorb the shortfall 1tself. If the shortfall exceeds $7 \%$ but is 1 ess than $12 \%$, each member must reduce consumption by $1 \%$; the remaining shortfall would be shared proportionately among all countries according to the IEP sharing formula. If oil supplies should fall short by $12 \%$ or more, each participating country must restrain demand by $10 \%$ and share whatever oil is still available with other member nations.

As a participant in the IEP, the United States has pledged to comply with its emergency provisions, whereby each member must have ready a program of contingency demand restraint measures which would be sufficient to reduce demand for oil by 7 and 10\% of normal consumption. These measures would likely be implemented in conjunction with shortage drawdown in case of an emergency, although the IEP agreement allows signatory countries to substitute drawdown of storage for use of demand restraine measures.

In the event of a severe petroleum shortage, three types of action are available to alleviate the adverse impact: actions to. increase domestic petroleum supplies and use alternative forms of energy; actions to distribute the available supply in an equitable manner; and actions to reduce public and private demand for energy. The authorities available to the president and other public officials for taking such actions comprise the basis of the country's energy shortfall management program. The need for energy conservation contingency plans should be viewed in the context of the actions described below.

(1) Increase domestic petroleum supplies and use alternative forms of energy.

The following is a discussion of several of the primary means available to the United States to increase petroleum supplies or substitute other forms of energy for petroleum on an emergency basis. In a serious emergency, the federal government would aggressively pursue some or all of these options.

(a) Increase domestic petroleum production.

In general, the United States does not have in place substantial excess crude oil production capacity and therefore is unable to increase 
domestic production by significant amounts during an emergency. However, some flexibility in domestic production does exist, and steps will be taken to assure that production is maximized during an emergency. Important to this effort is the need to provide adequate incentives during periods of relatively abundant supplies to assure that new reserves are discovered and developed, that enhanced oil recovery projects are undertaken, and that the production decline rate from existing wells is slowed and production is maintained as long as possible. In addition, in an emergency, Section 106 (42 U.S.C. 6214) of the Energy Policy and Conservation Act (EPCA) (Pub. L. 94-163) authorizes the president to require production of petroleum or natural gas at or in excess of the maximum efficient rate.

\section{(b) Draw down existing inventories.}

During periods of normal supply the nation has in inventory at various levels of distribution supplies of crude oil and refined petroleum products adequate to meet total national demand for several days. Much of the total inventory is necessary to maintain the supply system in normal operation (e.g., oil pipelines must be kept full for their efficient operation), but in general, stocks are usually adequate to provide for shortfalls of limited duration without any interruption of supply to consumers. At the beginning of January 1979, for example, crude oil stocks were estimated to be sufficient to deal with a crude oil shortfall of about 500,000 barrels a day for 60 days before reaching the level where refinery runs would have to be significantly curtailed.

Provisions of the Standby Petroleum Product Price and Allocation Regulations recently adopted by the Department of Energy ( 44 F.R. 3978, January 18, 1979) provide regulatory means by which stock levels can be properly managed in anticipation of and during a supply interruption. They provide that the department can update allocation base periods to reflect the most recent 12 -month period of normal supplies prior to the supply emergency, thus preventing purchasers from drawing down outdated and unneeded supply entitlements, and they allow the imposition of a mandatory allocation fraction on all suppliers in antiripation of a shortfall that will result in the building of inventories to desired levels.

\section{(c) Draw down strategic petroleum reserves.}

The Strategic Petroleum Reserve (SPR) authorized in Title I of the EPCA is scheduled to reach 750 million barrels in the 1985-86 time period. As of the end of February 1979, 76 million barrels of crude oil will be in underground storage, and the Department of Energy plans to have 248 million barrels in storage by May 1980. Initial withdrawal capability will be in place by September 1979 and can be put in place sooner if necessary. 


\section{(d) Increase use of coal and other alternate fuels.}

The Powerplant and Industrial Fuel Use Act of 1978 provides the president with emergency authority to ban the use of petroleum or natural gas as boiler fuel in an electric power plant or other major fuel-burning installation capable of using coal or another alternate fuel. This act also gives the president the authority to allocate coal as necessary. Emergency suspensions of air quality standards are also authorized by this law. Another way in which coal or other alternate fuels can be useful in a petroleum shortage involves the transfer of electricity through transmission lines from coal-burning or other alternate fuel power plants (including nuclear plants) to utilities which burn oil.

\section{(e) Increase use of natural gas.}

The Natural Gas Policy Act eliminated the pricing distinction between the intrastate and interstate gas markels. As a result of this action and other factors, gas supplies are relatively abundant and are available for use as substitutes for middle distillates and residual fuel oil in many markets. Propane, incremental supplies of which are derived from natural gas, is also currently available in abundant supplies.

During an interruption of petroleum supplies, utilities, industries, and commercial establishments will be encouraged to use gas, propane, and other abundant alternate fuels to the maximum extent practicable.

(2) Distribute the available supply in an equitable manner.

Supply distribution mechanisms do not increase supply, and they have 1.imited capability for use to generally reduce demand for energy. Their principal purpose during an emergency is to provide for the distribution of the available supply of crude and product in a manner designed to assure equity and serve national priorities.

The Department of Energy's Standby Crude 0il Allocation Regulations, issued on January 9, 1979 ( 44 F.R. 3418, January 16, 1979), provide for four separate, progressively broader crude oll allucaliun systems. Phase I, the current crude ofl buy-sell program, orders one or more of the 15 major refiners to supply crude oil to those small refiners (i.e., those with less than $175,000 \mathrm{bbl} /$ day of refining capacity) which have demonstrated that they have lost their normal crude supplies.

Phase II, a modification of the current buy-sell program, would permit emergency allocation orders to supply major and large independent reliners.

Phase III, which could be activated in a more severe general crude oil shortage involving more than just a few major and large independent 
refiners, would require that the current program be maintained for small refiners and that a separate standby program be implemented for major and large independent refiners. Under such a scheme, the large firms would share their available oil with small refiners as under the present program and with each other on a historic usage-current supply basis. In this instance, a national average supply ratio for the larger firms would be determined. Firms having more oil than the average would sell crude to those having less.

The last standby crude allocation response, for use in more extreme emergencies, would involve every refiner in the country in the same allocation scheme, eliminating the current small refiner program. All refiners' available oil and historical runs to stills would be used to calculate a national utilization rate. Refiners with more oil than the national average, including small refiners, would sell to those with less. Under some circumstances certain small refiners could be exempted from sale obligations, and in any event they would receive a slightly better price on buy-sell transactions than large refiners.

The Standby Petroleum Product Allocation and Price Regulations, published in final form by DOE on January 18, 1979 (44 F.R. 3978), provide DOE with broad new authority to allocate available supplies of refined petroleum products.

- Most petroleum products are not currently subject to allocation and price controls. Only gasoline, naphtha for synthetic natural gas plant feedstocks, and natural gas liquid products are subject to controls. For those products that are not then subject to controls, DOE may in an emergency reactivate price and allocation controls through the standby product regulations, and DOE can also switch those products currently under control to the new regulations. These standby regulations may be activated to address a petroleum product supply shortage on a national basis, or on a regional basis if needed only to deal with localized supply dislocations.

A standby gasoline rationing plan is being submitted to the Congress for its approval. Because of the high cost of rationing, the complexity of Its adminiseration, and the inevitable disruptions it would cause, this plan is intended for implementation only in the event of a severe gasoline supply shortfall.

(3) Reduce public and private demand for energy.

Conservation programs seek to reduce energy consumption by promoting greater efficiency and discouraging wasteful energy usage. During an emergency energy shortage, ongoing mandatory and voluntary conservation programs such as the 55-mph speed limit and carpooling could be intensified, and other steps for the elimination of nonessential energy usage could be taken. Individual states could implement their own conservation contingency plans, as provided for within Part C (42 U.S.C. 6321-6326), of Title III of the EPCA, and take other actions as appropriate. 
During a severe and prolonged shortfall, even though greater reductions in demand for energy far outweigh the supply, it is impossible to meet normal energy requirement and, even with the invocation of the above mandatory and voluntary measures, a large gap between supply and demand would remain. Assuming price controls, this gap would be narrowed only by temporarily curtailing or eliminating normal energy-consuming activities and habits.

The primary objective in formulating standby energy conservation plans is to identify those normal energy demands which can and should be cut back or eliminated on a short-term basis in order to minimize the impact of an energy shortage situation. The rationale for the selection of the Restricted Hours of Operation for Commercial Buildings Plan as a standby energy conservation measure is described in the following section.

\section{H.2.2 Rallunale of llie plan}

In developing the standby energy conservation plans, DOE revlewed more than 250 potential measures relating to all types of energy consumption in the transportation, commercial, residential, and industrial sectors. Each potential measure was evaluated in the light of various constraints that were imposed by the EPCA and other criteria developed by DOE.

The following evaluation criteria were used in the selection process.

(1) No plan may be based on the use of rationing, taxes, tariffs, user fees, pricing mechanisms for petroleum products, or tax credits or deductions.

Thio reotriction io imposed by Ecction 202 (a) (2) of the EPCA [42 U.S.C. 6262 (a) (2)] and eliminates from consideration measures which would reduce demand through mechanisms such as a tax rebate system, a tax on gasoline, or an electricity bill surcharge.

\section{(2) Plans must be capable of rapid payoff.}

This criterion is based on the assumption that certain types of emergencies will occur suddenly, and also on the provision in Section 201 (a) (1) of the EPCA [42 U.S.C. 6261(a) (1)] that no contingency plan may remain in cffect more than nine months. Therefore, no measure was selected which could not have a significant demand restraint impact within 45 days following a decision to implement it.

\section{(3) Plans must be enforceable by federal authorities.}

Although the states and localities might implement and enforce their own emergency conservation plans in the event of an energy shortage and will also be called upon to assume the delegation of enforcement and 
other functions under the federal plans, these plans have been developed in such a way that they can be fully implemented and enforced at the federal level if necessary. Coordination with state and local officials will be an essential element of the enforcement strategy.

(4) The potential for energy demand reduction must be significant.

Only those measures were selected which offered the potential for a. significant reduction in energy demand, either directly or through the capacity to heighten overall public awareness of the emergency situation and the need to conserve. In some cases, the lack of historical experience and the need to make many assumptions regarding human behavior make estimates of demand reduction for some proposed measures difficult to validate.

(5) No measure should impose an undue hardship on any sector of the economy.

Section 521 of the EPCA (42 U.S.C. 6391), referring in part to the contingency plans, provides as follows:

"To the maximum extent practicable, any restriction ... on the use of energy shall be designed to be carried out in such a manner so as to be fair and create a reasonable distribution of the burden of such restriction on all sectors of the economy, without imposing an unreasonably disproportionate share of such burden on any specific class of industry, business, or commercial enterprise or any individual segment thereof."

This requirement of the EPCA was considered in the selection and development of plans. Such consideration is set forth in the economic analysis of each plan prepared pursuant to Section 201(f) of the EPCA. Section 201(f) provides in part that any contingency plan "be based upon a consideration of ... the potential economic impacts of such plans."

The 1mpact of plans on the varlous sectors of the economy was analyzed from a baseline which assumes an energy shortfall that in and of itself would have a substantial impact upon the nation's economy. In general; potential conservation plans that would not have a favorable overall impact measured from this baseline situation were rejected from consideration.

(6) No plan should deal with more than one logically consistent subject matter.

EPCA further requires, in Section $202(\mathrm{c})$, that a conservation contingency plan "shall not deal with more than one logically consistent subject matter." 
The above criteria form a rather substantial barrier against most proposed mandatory conservation measures. A preliminary evaluation of the Restricted Hours of Operation for Commercial Buildings Plan measured against the criteria would show:

\section{Criteria}

1. No rationing, taxes, etc.

2. Rapid payoff in energy.

3. Enforceable by federal authorities.

4. Substantial energy savings.

5. No undue hardship on any sector.

6. Single subject matter. $\underline{\text { Plan }}$

Does not ration or tax.

Could be implemented quickly if sufficient preplanning were included. Demand reduction follows quickly.

Not.really enforceable without a large degree of state agency and private sector cooperation.

At maximum, the plan could save $1 / 3 \mathrm{Q}$ of o11 and gas and $1 / 2$ Q of cotal energy. A $10 \%$ petroleum shortfall would be about $4 \mathrm{Q}$ of petroleun.

The measure would have significant income and employment impacts. Regions of the country that use little oil would incur economic impacts without benefit of direct oil saving.

The measure restricts hours of commercial operation and sperifies thermostat setting during hurrs ut closure.

Whether the Restricted Hours of Operation for Commercial Buildings Plan sufficiently fulfills the EPCA criteria is a matter to be decided by ERA, the Secretary, and Congress. Sections 3-6 of this report provide. details regarding estimated fuel savings and economic and environmental impacts.

\section{H.2.3 Operation of the plan}

The Restricted Hours of Operation for Commerclal Buildings Plan would be implemented in conjunction with a closely related standby conservation plan, the Emergency Building Temperature Restriction Plan. This latter plan restricts winter thermostat settings to $65^{\circ} \mathrm{F}$, summer settings to $80^{\circ} \mathrm{F}$, and hot-water settings to $105^{\circ} \mathrm{F}$. This plan has been prepared for consideration by the president and Congress. The restricted hours plan may be thought of as a supplement to the temperature restriction plan. 
The Restricted Hours of Operation for Commercial Buildings Plan would require that owners of commercial buildings limit the hours of commercial operation to a maximum of $60 \mathrm{hr} /$ week. Several alternative patterns of hours, each totaling $60 \mathrm{hr}$, would be available. During the $108 \mathrm{hr} /$ week of closure, building temperatures would be further regulated beyond the temperature restriction plan. In winter, thermostat settings would be reduced to $55^{\circ} \mathrm{F}$ during hours of closure, and in summer all cooling would be shut off during hours of closure.

The plan would also require that thermostats be maintained within reasonable tolerances of accuracy in order to ensure that actual temperature levels would be consistent with the required thermostat settings.

Bulldings covered by the requirements of the plan include retail and wholesale establishments, entertainment facilities, government and private office buildings, finance, insurance, real estate, repair services, and the like. Specifically excluded from coverage are buildings in which over $50 \%$ of the gross square footage is used for residential purposes, hotels and other lodging facilities, and hospitals and other health care facilities. The plan also exempts from the heating and cooling restrictions those buildings or areas of buildings where spectfied temperature levels are required by manufacturers' warranties for the operation of special equipment (such as electronic data processing machinery) or where special environmental conditions are necessary in order to protect animal or plant life or materials.

With respect to buildings which include both commercial and residential space, it is intended to adopt regulations which will, to the extent practicable, apply only to the commercial space. Where a significant portion of a building is legitlmately used for residential purposes and the individual units are not and cannot readily be equipped. with their own thermostats, the entire building will generally be exempt.

Within 30 days of activation of the plan by the president, the owner of each building covered by the plan would be required th execute a self-certification form certifying compliance with the provisions of the plan. The completed form would be displayed in a prominent location in the appropriate building.

Responsibility for implementation, administration (including determination of exceptions), monitoring, and enforcement would be with DOE. However, DOE will delegate enforcement and exception functions to those states that are willing to accept them on a cost reimbursable basis, and in those cases DOE will provide general guidance and assistance, plus concurrent enforcement authority to deal with cases of great public importance. It is contemplated that where DOE retains enforcement authority, enforcement actions would follow procedures used by DOE to enforce other programs for which it has responsibility. These procedures would include on-site inspections conducted by DOE enforcement personnel. 
The plan would apply in each state (including the District of Columbia, Puerto Rico, or any territory or possession of the United States) or political subdivision thereof and preempt inconsistent state or local law. The plan would provide, however, that the president or his delegate may, on his own initiative or in response to a request for exemption, exempt a state or political subdivision thereof from its application, in whole or in part, if the president or his delegate determines a comparable program is in effect or finds special circumstances exist in such state or political subdivision. These provisions are pursuant to Section 202(b) of the EPCA. 
ORNL/TM-7059

INTERNAL DISTRIBUTION

1. S. I, Auerbach

2. S. E. Beall

3-27. F. D. Boercker

28. R. S. Carlsmith

29. R. M. Davis

30. W. Fulkerson

31. R. B. Honea

32-67. D. Jared

68. S. V. Kaye

69-72. A. S. Loeb1

73. W. R. Mixon

74. D. C. Parzyck
75. T. H. Row

76. J. W. Sims

77. T. Wilbanks

78. D. J. Wilkes

79. Biology Division Library

80-81. Central Research Library

82. Institute for Energy Analysis, ORAU

83. Laboratory Records, ORNL (R.C.)

84-86. Laboratory Records Department

87. ORNL Patent Office

88. Document Reference Section

\section{EXTERNAL DISTRIBUTION}

89-289. Energy Division, Regional and Urban Studies Distribution 290-316. Technical Information Center, Department of Energy, P.0. Box 62, Oak Ridge, TN 37830

317-327. Benton Masse11, Director, Emergency Planning Division, Economic Regulatory Administration, DOE, 2000 " $\mathrm{M}$ " St., Washington, DC 20461

328. Office of Assistant Manager for Energy Research and Development, DOE-ORO 